\title{
15. GEOTECHNICAL PROPERTIES OF MIDDLE AMERICA TRENCH SEDIMENTS, DEEP SEA DRILLING PROJECT LEG $6^{1}{ }^{1}$
}

\author{
L. E. Shephard, ${ }^{2}$ W. R. Bryant, and W. A. Chiou, Department of Oceanography, \\ Texas A\&M University, College Station, Texas
}

\section{INTRODUCTION}

Delineating the interrelationships between tectonics, sedimentation, and geotechnical properties is particularly important for areas subjected to the dynamic affects of convergence. DSDP Leg 66 drilling within the Middle America Trench complex provided a unique opportunity to investigate these interrelationships along a transect of eight drill sites beginning on the trench outer slope and traversing the trench, trench inner slope, and upper continental slope (Fig. 1). Investigations of other convergent margins suggest that deformation occurs most rapidly along the lower trench inner slope and is reflected by the geotechnical properties (Carson, 1977; Seely, 1977; and von Huene, 1979). This study focuses on the geotechnical properties of Middle America Trench sediments and the possible affects of convergence on these properties.

\section{TECHNIQUES}

Routine geotechnical property measurements, tabulated in the Appendix at the end of this chapter, include (1) bulk density $\left(\mathrm{Mg} / \mathrm{m}^{3}\right),(2)$ porosity $(\%),(3)$ water content ( $\%$ total weight), (4) undrained shear strength $(\mathrm{kPa})$, and $(5)$ compressional sound velocity $(\mathrm{km} / \mathrm{s})$. Shipboard measurements and computations were performed utilizing procedures, equipment, correction factors, and standards outlined by Boyce $(1975,1977)$. Evaluations, recurring problems, and sources of errors for many of these techniques are summarized by Bennett and Keller (1973) and Demars and Nacci (1977), hence only modifications to these procedures and specific problems pervasive to Leg 66 analyses will be discussed.

Good core recovery at most sites allowed regular sampling from least disturbed core sections. Core disturbance resulting from normal drilling and handling operations appeared limited, but some cored intervals of gassy sediments were very disturbed and displayed expansion features and erratic values of geotechnical properties. Technical problems prevented logging, except through the drill pipe, thus precluding any correlations with in situ physical properties. All index properties reported are uncorrected for salt content.

Bulk density and porosity were determined shipboard by continuous gamma ray attenuation of unsplit cores and by two-minute gamma ray and gravimetric analyses of rock chunk samples. Shorebased measurements were performed utilizing an air comparison pycnometer. Initial Reports volumes are replete with discussions of GRAPE (gamma ray attenuation and porosity evaluator) data. Although these data are presented graphically in the site chapters and in the geotechnical property summary tables at the conclusion of this chapter to follow previous DSDP format, all interpretations of porosity and bulk density data are based on gravimetric and air comparison pycnometer data. Grain and fluid densities of $2.70 \mathrm{Mg} / \mathrm{m}^{3}$ and 1.025

\footnotetext{
1 Initial Reports of the Deep Sea Drilling Project, Volume 66. ${ }^{2}$ Present address: Sandia National Laboratories, Division 4536, Albuquerque, New
}

$\mathrm{Mg} / \mathrm{m}^{3}$ were used in all shipboard GRAPE computations (Boyce, 1975).

Gravimetric and air comparison pycnometer samples were carefully selected to alleviate many of the problems associated with drilling disturbance. Gas-related sediment disturbance was often restricted in 2- to 3-meter zones, permitting sampling in least disturbed core subsections. Large samples $\left(\geq 10 \mathrm{~cm}^{3}\right)$ improved reproducibility and confidence in volume measurements for porosity and bulk density computations. Sediment spalling and fissility with increased induration prevented some gravimetric measurements. Water content ( $\%$ total weight) was determined for all samples analyzed gravimetrically or by the air comparison pycnometer. Large $(\simeq 20 \mathrm{~cm})$ rock chunk samples were also used for determining water content and porosity. Porosity values obtained from the rock chunk samples were computed assuming $100 \%$ sample saturation and using an average grain density value determined for major lithologic units at each site.

Undrained shear strengths were determined using a WykehamFarrance vane shear rotating $89^{\circ}$ per minute and a Cl-600 Torvane. All measurements were performed parallel to bedding on split core sections. Premature sediment failure by cracking often prevented testing of samples having strengths greater than $100 \mathrm{kPa}$. Reasonably good agreement was obtained between vane shear and Torvane results.

Compressional sound velocity measurements, performed utilizing a Hamilton-Frame velocimeter emitting a $400-\mathrm{kHz}$ sonic signal, were limited by signal attenuation due to gas, even over short $(<1 \mathrm{~cm})$ travel paths. Most measured velocities are lower than those calculated from multichannel seismic reflection data, further decreasing confidence in shipboard measurements.

Consolidation tests were performed utilizing Anteus back-pressure consolidometers. The primary advantages of the Anteus unit and the general procedures employed can be found in Lowe et al. (1964) and Bowles (1970). Casagrande's technique (1936) was used to determine the preconsolidation pressure, $P_{c}$, which is the maximum pressure a sediment has been consolidated to in the past. Comparing the preconsolidation pressure to the effective overburden pressure $P_{o}^{\prime}$ (calculated assuming linear hydrostatic pore pressure conditions) determines the state of consolidation. According to soil mechanics terminology, a normally consolidated sediment has fully consolidated under the present effective overburden pressure $\left(P_{c}=P_{o}^{\prime}\right)$. Overconsolidated sediments have been consolidated to a pressure in excess of the present effective overburden pressure $\left(P_{c}>P_{o}^{\prime}\right)$. Underconsolidated sediments have not fully consolidated under the present effective overburden pressure $\left(P_{c}<P_{o}^{\prime}\right)$.

All consolidation test samples were carefully selected on the basis of minimum disturbance. Split cores above and below the consolidation sample (whole round core segment) were examined visually shipboard to determine qualitatively the relative degree of sediment disturbance. Prior to testing in the laboratory all core samples were radiographed to further delineate core quality and potential core disturbance. Despite these precautions core disturbance does occur, especially in zones of high gas content.

Index of disturbance $I_{D}$, a technique for quantifying consolidation sample disturbance using the $e-\log P$ curve (Silva, 1975), was applied to these samples. Most $I_{D}$ values fall within the range 0.25 to 0.45 , which is considered low to moderate disturbance. Bennett et al. (1977) have shown that for sediments with initial porosities of less than $65 \%$ the disturbance index technique is biased toward higher $I_{D}$ values for the same relative amount of disturbance. Thus the disturbance index criterion classifies the most disturbed consolidation sample tested as 


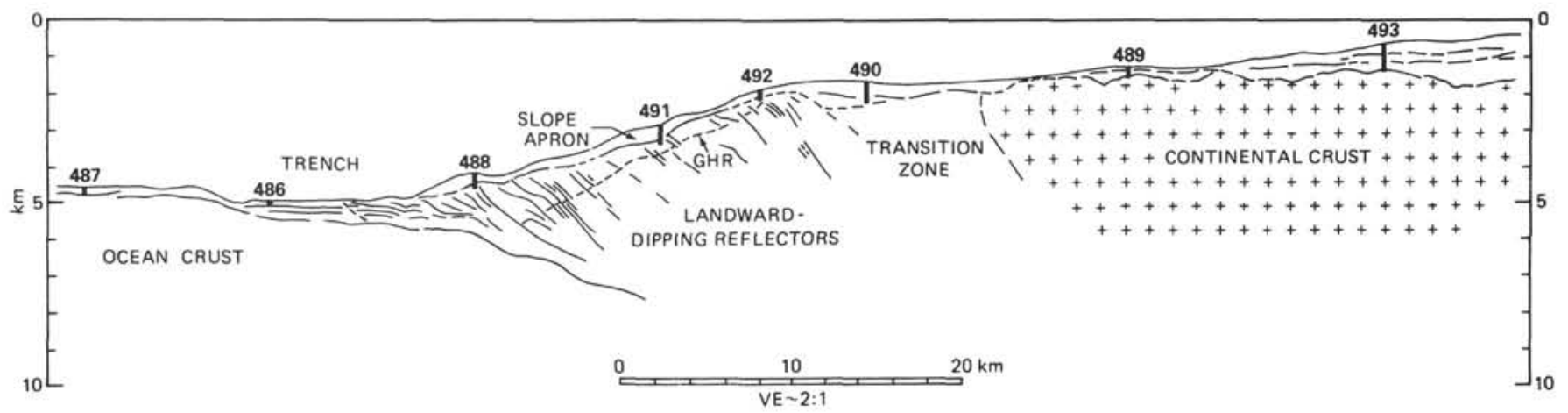

Figure 1. Schematic cross section of Middle America Trench showing appropriate locations of eight drill sites studied.

moderately disturbed. To interpret the state of consolidation, computed preconsolidation pressures were assumed to represent minimum values, which are lower than actual in situ preconsolidation values (Schmertmann, 1955).

\section{RESULTS}

\section{Site 487}

Drilling at Site 487 , located on the trench outer slope of the seaward plate (Fig. 1), penetrated 105 meters of Quaternary hemipelagic silty clays overlying 67 meters of upper Miocene to Pliocene brown pelagic clays. Geotechnical analyses of these sediments (Fig. 2) reveal subtle differences corresponding to changes in lithology and/or sedimentation rate.

Water content increases from $50 \%$ at the sediment water interface to $58 \%$ at 12 meters, then remains fairly constant to 158 meters sub-bottom. Inflections in the water content depth profile at 103 and 134 meters bracket the transition from predominantly hemipelagic Quaternary silty clays to Pliocene-upper Miocene pelagic clays. This transition results in decreased sedimentation rates and changes in dominant lithologic types. Concomitant changes occur for porosity and bulk density; from $80 \%$ to $75 \%$ and $1.35 \mathrm{Mg} / \mathrm{m}^{3}$ to $1.44 \mathrm{Mg} / \mathrm{m}^{3}$ at the surface and 158 meters, respectively.

The lack of significant changes in these properties in the upper 150 meters appears consistent with values reported for pelagic sediments at other sites (Hamilton, 1976). The inflections in the index property gradients at 103 and 134 meters probably reflect in situ trends. No apparent increase in core disturbance, either mechanical or gas-related, occurs at these depths.

Compressional velocity increased gradually from 1.45 $\mathrm{km} / \mathrm{s}$ to $1.54 \mathrm{~km} / \mathrm{s}$ at 102.5 meters. Below this depth, velocity remains relatively constant. These values are within the expected range for high-porosity clays and silty clays, using the relationships developed by Nafe and Drake (1957) and Cernock (1970).

Shear strength remains relatively constant $-15 \mathrm{kPa}-$ to a depth of 40 meters. Values appear to increase gradually at greater depths, exceeding $100 \mathrm{kPa}$ at 112 meters. Scatter in the shear strength profile results from premature failure by cracking and may also reflect zones of disturbance not evident visually. Shear strength, effective overburden pressure ratios $\left(C_{u} \cdot P_{o}^{\prime-1}\right)$ range from 0.11 at the mudline to 0.20 at 140 meters, indicating that these sediments are underconsolidated according to the range of values $(0.2-0.5)$ suggested for normally consolidated marine clays (Skempton, 1970).

Three consolidation tests (Fig. 3 and Table 1) performed on sediments from this site also show the sediments to be underconsolidated. Problems incurred while loading Sample 487-18-5 and the absence of a well-defined break in slope on the $e$-log $P$ curve limit confidence in the preconsolidation pressure determined for this test. These results concur with those expected based on the porosity and water content profiles, and indicate that very little dewatering has occurred within the sediment cored.

\section{Site 488}

Site 488 was located approximately $4 \mathrm{~km}$ from the trench axis at the base of the trench inner slope. Drilling penetrated 313 meters of middle to upper Quaternary clayey silts, which overlie 115 meters of lower to middle Quaternary clayey silts interbedded with sand. These sands vary in thickness from less than a meter to several meters. Geotechnical analyses (Fig. 4) were limited to the clayey silt sediments penetrated at this site. Attenuation of the sonic signal by gas precluded any compressional sound velocity measurements.

Porosity gradually decreases from near-surface values of $70 \%$ to $49 \%$ at 210 meters (Fig. 4). From 210 to 235 meters porosity abruptly decreases to $35 \%$, then gradually increases to $45 \%$ at 300 meters. Below 300 meters porosity again decreases, although limited core recovery and increasing amounts of scatter due to fissility and variations in silt content have resulted in a poorly defined trend.

Water content and bulk-density depth profiles reveal trends similar to the porosity depth profile trend. Water content decreases gradually $(47 \%-27 \%)$ to 210 meters sub-bottom, then abruptly decreases over a 25 -meter interval to $14.5 \%$ at $235 \mathrm{~m}$. Below 235 meters water content increases $(14.5 \%-33 \%)$ to 300 meters, then gradually decreases to 400 meters sub-bottom $(33 \%-15 \%)$. Bulk density increases gradually $\left(1.53 \mathrm{Mg} / \mathrm{m}^{3}-1.75\right.$ $\mathrm{Mg} / \mathrm{m}^{3}$ ) to 210 meters sub-bottom, then abruptly increases between 210 and 235 meters $\left(1.75 \mathrm{Mg} / \mathrm{m}^{3}-2.05\right.$ $\left.\mathrm{Mg} / \mathrm{m}^{3}\right)$. A decrease in bulk density $\left(2.05 \mathrm{Mg} / \mathrm{m}^{3}-1.88\right.$ $\mathrm{Mg} / \mathrm{m}^{3}$ ) occurs from 235 to 300 meters, then bulk density again increases $\left(1.88 \mathrm{Mg} / \mathrm{m}^{3}-1.98 \mathrm{Mg} / \mathrm{m}^{3}\right)$ to a subbottom depth of 400 meters. 


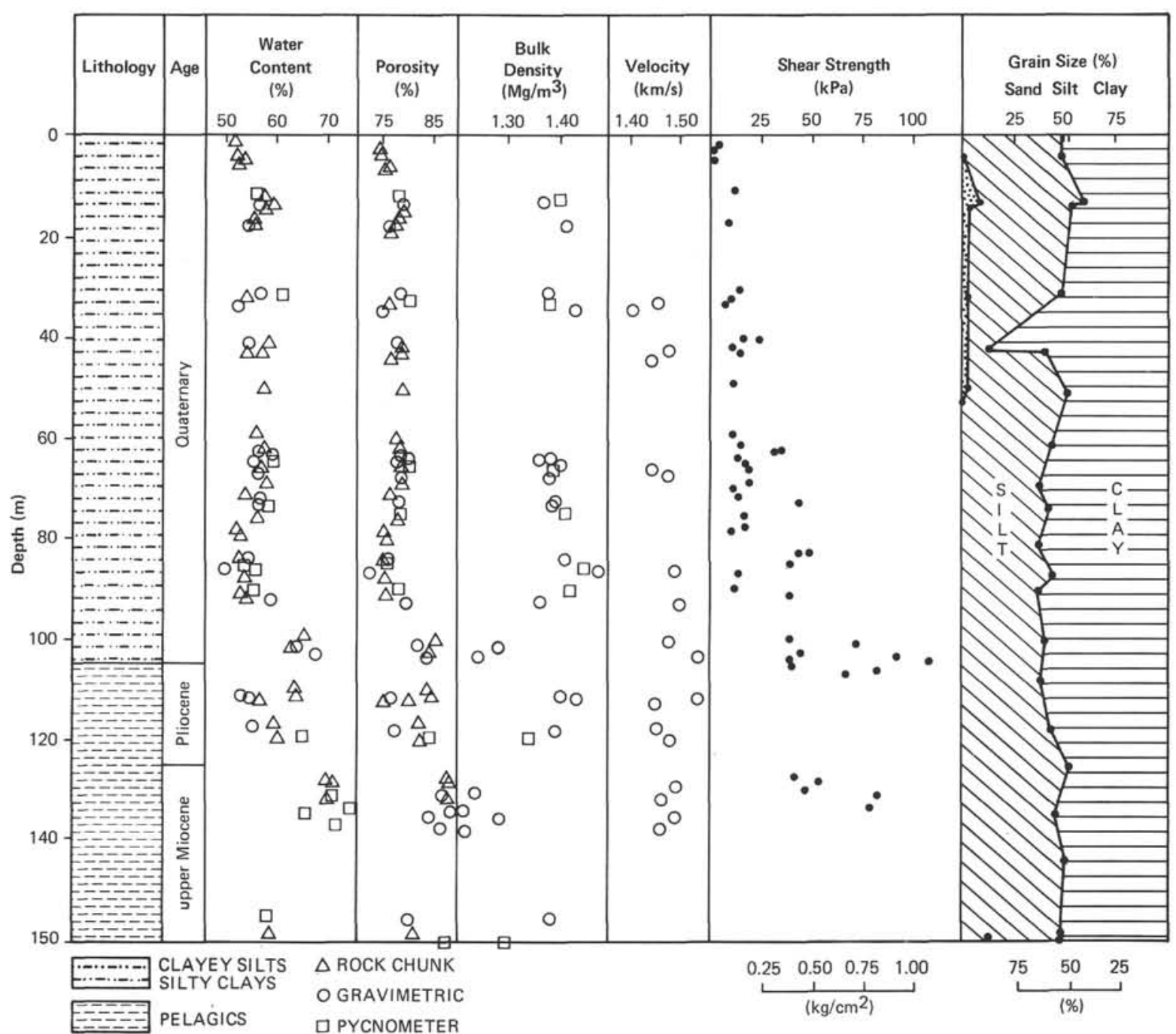

Figure 2. Geotechnical property summary profiles, Site 487.

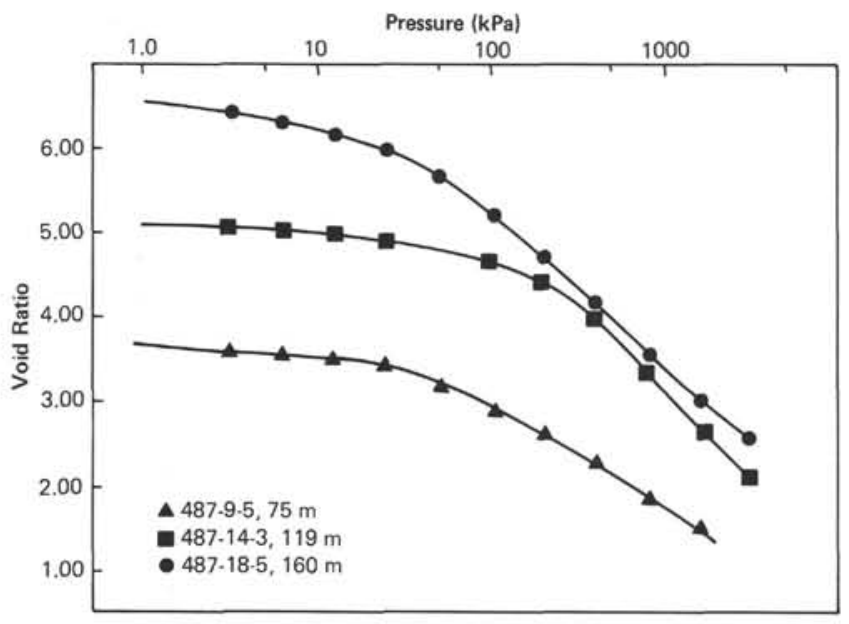

Figure 3. Void ratio versus logarithm of pressure curves $e-\log P$ for Site 487 samples.

Shear strength (Fig. 4) increases uniformly from 4.4 $\mathrm{kPa}$ at 3.3 meters to $98 \mathrm{kPa}$ at 202 meters. The scatter on the shear strength profile results from premature failure by cracking and possibly from variations in dis- turbance not evident visually. Ratios of undrained shear strength to effective overburden pressure $C_{u} \cdot P_{o}^{\prime-1}$ for maximum shear strengths measured at a particular depth gradually decrease from 0.14 at 25 meters to 0.09 at 170 meters. These values are lower than those proposed by Skempton (1970) for normally consolidated marine clays and suggest that these sediments are underconsolidated.

Ten consolidation tests were performed on Site 488 sediments (Fig. 5; Table 2). Test results indicate that Sample 488-2-3 $(4.0 \mathrm{~m})$ is overconsolidated; remaining inner trench slope samples are underconsolidated.

Underconsolidated sediments at depth agree with predictions based on shear strength data. Overconsolidation ratios (OCR) are fairly consistent below 10 meters sub-bottom (0.20-0.41), except for Sample 488-26-2 $(0.04 ; 238 \mathrm{~m})$. These constant $\mathrm{OCR}$ values indicate that sediments are not becoming more underconsolidated with depth, as was evident within the Japan Trench complex (Shephard and Bryant, 1980), but that excess pore pressures associated with these sediments are dissipating to a certain degree commensurate with accumulating overburden. The low OCR value for Sample 488- 
Table 1. Consolidation test results and geotechnical properties of samples tested from Site 487.

\begin{tabular}{ccccccccc}
\hline & $\begin{array}{c}\text { Depth below } \\
\text { Seafloor } \\
(\mathrm{m})\end{array}$ & $\begin{array}{c}\text { Bulk } \\
\text { Density } \\
\left(\mathrm{Mg} / \mathrm{m}^{3}\right)\end{array}$ & $\begin{array}{c}\text { Porosity } \\
(\%)\end{array}$ & $\begin{array}{c}\text { Water } \\
\text { Content } \\
(\%)\end{array}$ & $\begin{array}{c}\text { Void } \\
\text { Ratio }\end{array}$ & $\begin{array}{c}\text { Effective } \\
\text { Overburden } \\
\text { Pressure } \\
(\mathrm{kPa})\end{array}$ & $\begin{array}{c}\text { Preconsolidation } \\
\text { Pressure } \\
(\mathrm{kPa})\end{array}$ & $\begin{array}{c}\text { Overconsolidation } \\
\text { Ratio }\end{array}$ \\
\hline Hole 487 & & & & & & & & \\
$9-5$ & 75 & 1.41 & 78.56 & 58.86 & 3.67 & 287 & 70 & 0.24 \\
$14-3$ & 119 & 1.34 & 84.19 & 64.16 & 5.33 & 440 & 310 & 0.71 \\
$18-5$ & 160 & 1.29 & 86.67 & 68.44 & 6.50 & 559 & 60 & 0.11 \\
\hline
\end{tabular}

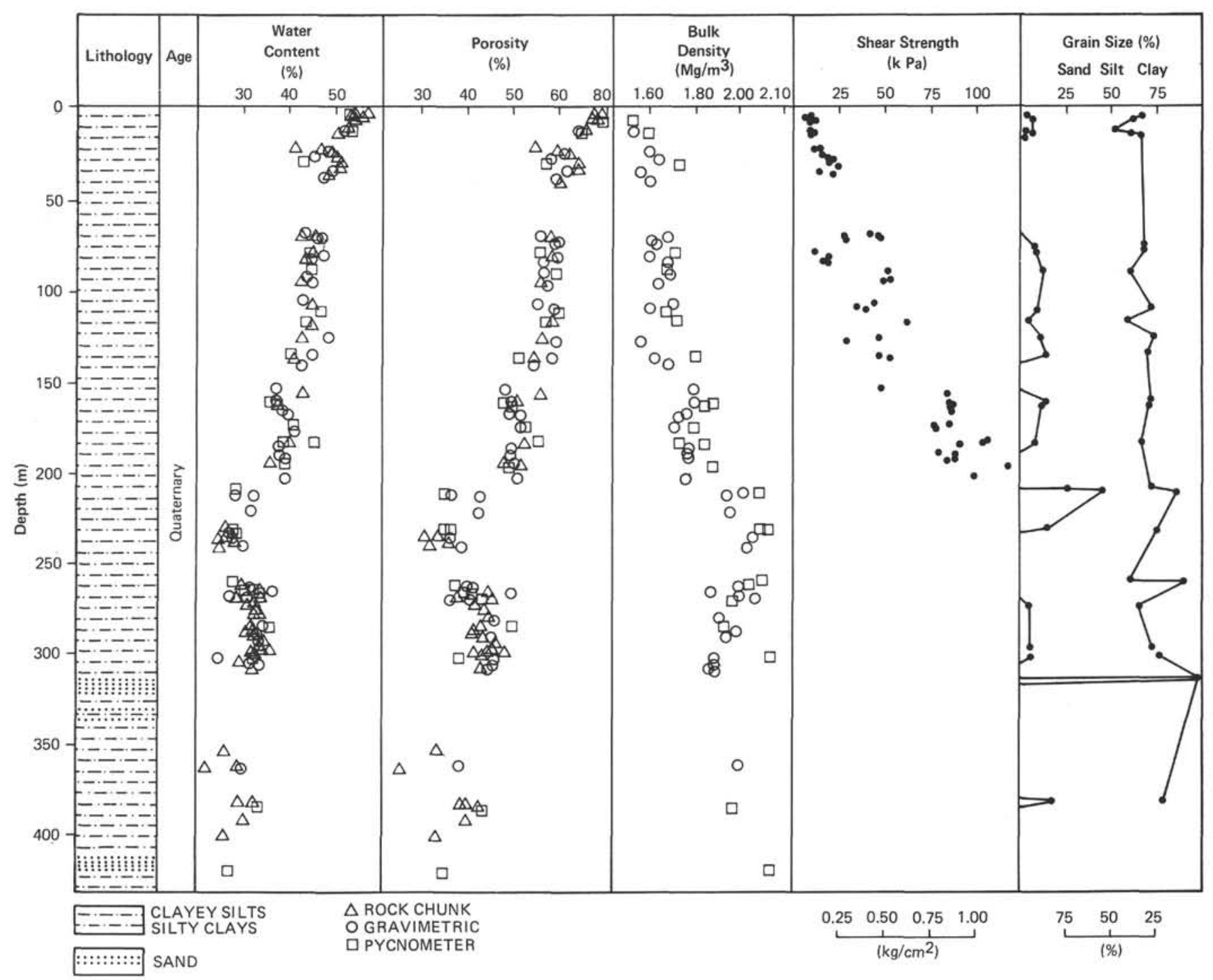

Figure 4. Geotechnical property summary profiles, Site 488.

26-2 appears related to increased sediment deformation evident as truncated bedding, variable bedding attitudes, and inclined fractures in sediments above and below the consolidation sample. An increase in fine sand and a disrupted, chaotic clay fabric which appears to have formed in situ may also contribute to the anomalously low OCR value.

No anomalies in the geotechnical properties are evident in the upper 200 meters, which can be correlated with the thrust fault evident on the site survey seismic reflection profiles (Shipley, this volume). However, Shipley has identified a nearly horizontal coherent reflection occurring very near the depth of the geotechnical properties anomaly at $\mathbf{2 3 5}$ meters. Cores obtained through this zone show steeply dipping and truncated beds as well as inclined fractures, which suggest deformation resulting from tectonic or mass movement processes. Extrapolation of the bulk properties trend 

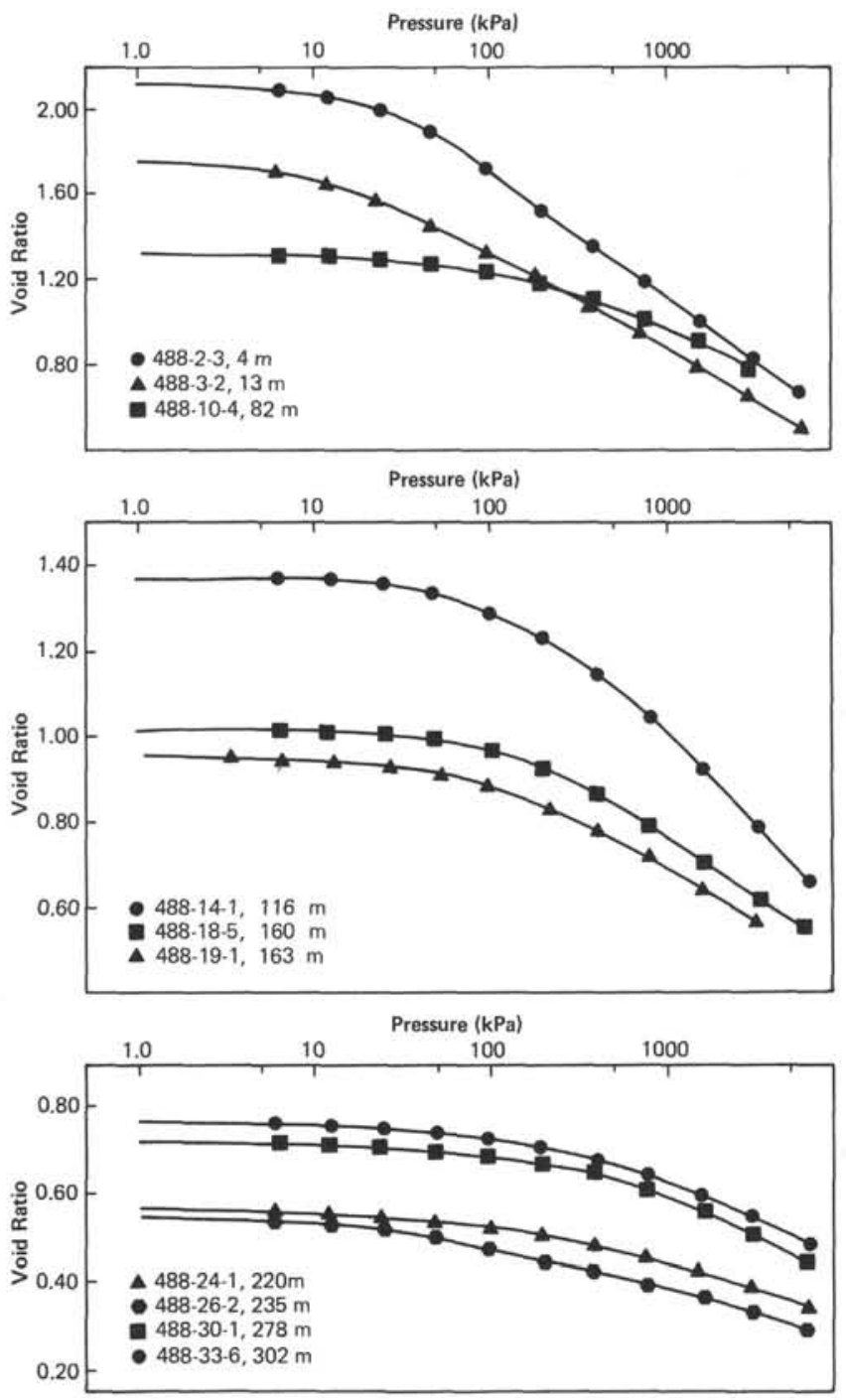

Figure 5. Void ratio versus logarithm of pressure curves, $e-\log P$ for Site 488 samples.

developed in the upper 200 meters to below the anomalous zone results in values of porosity, water content, and bulk density very close to those values actually measured. Woodbury et al. (1978) studied a large sediment mass in the Gulf of Mexico, displaying very similar geotechnical property trends with depth, which they interpreted as a major slump block.

Transmission electron micrographs of ultrathin sections $(\simeq 800 \AA-1000 \AA$ thick $)$ from sediments above, below, and within the zone of deformation reveal definite changes in clay fabric (Fig. 6). Micrographs of Sample 488-20-1 $(180 \mathrm{~m})$ show a preferentially oriented clay fabric consisting of domains of clay particles, some of which appear oblique to the preferred direction of orientation. This type of fabric probably results from natural consolidation processes due to increasing overburden pressure. Micrographs of Samples 488-24-1 and 488-26-2 (220 and $235 \mathrm{~m}$, respectively) reveal a different clay fabric. Sample 488-24-1 clay fabric consists of welldefined domains which appear randomly oriented. Sample 488-26-2 clay fabric appears more disrupted with fewer well-defined domains and an increase in electron dense particles. Micrographs of Sample 42-6 (385 m), located below the zone of deformation, show welldefined and highly oriented domains probably indicative of normal gravitational compaction processes.

Deformation of Site $\mathbf{4 8 8}$ sediments evident visually, evident in the geotechnical property profiles, and evident in electron micrographs of ultrathin sections is most pervasive between 210 and 250 meters sub-bottom. This zone of deformation appears related to the convergence process either directly by the deformation of lower slope sediments during accretion and subsequent uplift of underlying trench sediments or indirectly by inducing excess pore pressures and oversteepened slopes resulting in mass movement. Regardless of the mechanism, this zone represents one type of soft sediment deformation occurring on the lower trench inner slope. An increase in the silt and fine sand size fractions may also have some effect on the geotechnical properties and clay fabric of these sediments.

\section{Site 489}

Drilling at Site 489 , located over continental crust, penetrated 5.5 meters of Quaternary clayey silts unconformably overlying 295 meters of Miocene clayey silts. Geotechnical analyses (Figure 7) reveal subtle changes in the index property gradients, particularly below 50

Table 2. Consolidation test results and geotechnical properties of samples tested from Site 488 .

\begin{tabular}{ccccccccc}
\hline & $\begin{array}{c}\text { Depth below } \\
\text { Seafloor } \\
(\mathrm{m})\end{array}$ & $\begin{array}{c}\text { Bulk } \\
\text { Density } \\
\left(\mathrm{Mg} / \mathrm{m}^{3}\right)\end{array}$ & $\begin{array}{c}\text { Porosity } \\
(\%)\end{array}$ & $\begin{array}{c}\text { Water } \\
\text { Content } \\
(\%)\end{array}$ & $\begin{array}{c}\text { Void } \\
\text { Ratio }\end{array}$ & $\begin{array}{c}\text { Effective } \\
\text { Overburden } \\
\text { Pressure } \\
(\mathrm{kPa})\end{array}$ & $\begin{array}{c}\text { Preconsolidation } \\
\text { Pressure } \\
(\mathrm{kPa})\end{array}$ & $\begin{array}{c}\text { Overconsolidation } \\
\text { Ratio }\end{array}$ \\
\hline Hole 488 & & & & & & & & \\
$2-3$ & 4 & 1.53 & 68.84 & 45.77 & 2.21 & 22 & 50 & 2.24 \\
$3-2$ & 13 & 1.59 & 65.36 & 41.65 & 1.89 & 71 & 20 & 0.28 \\
$10-4$ & 82 & 1.71 & 56.28 & 34.43 & 1.29 & 483 & 130 & 0.27 \\
$14-1$ & 116 & 1.72 & 57.15 & 33.55 & 1.33 & 641 & 260 & 0.41 \\
$18-5$ & 160 & 1.88 & 48.09 & 25.86 & 0.93 & 930 & 180 & 0.19 \\
$19-1$ & 163 & 1.84 & 49.97 & 27.48 & 1.00 & 953 & 200 & 0.21 \\
$24-1$ & 220 & 2.14 & 34.84 & 16.94 & 0.54 & 1302 & 400 & 0.31 \\
$26-2$ & 235 & 2.08 & 35.89 & 17.97 & 0.56 & 1516 & 50 & 0.03 \\
$30-1$ & 278 & 1.99 & 40.95 & 21.51 & 0.69 & 1853 & 600 & 0.32 \\
$33-6$ & 302 & 1.96 & 42.90 & 22.00 & 0.75 & 2196 & 650 & 0.30 \\
\hline
\end{tabular}




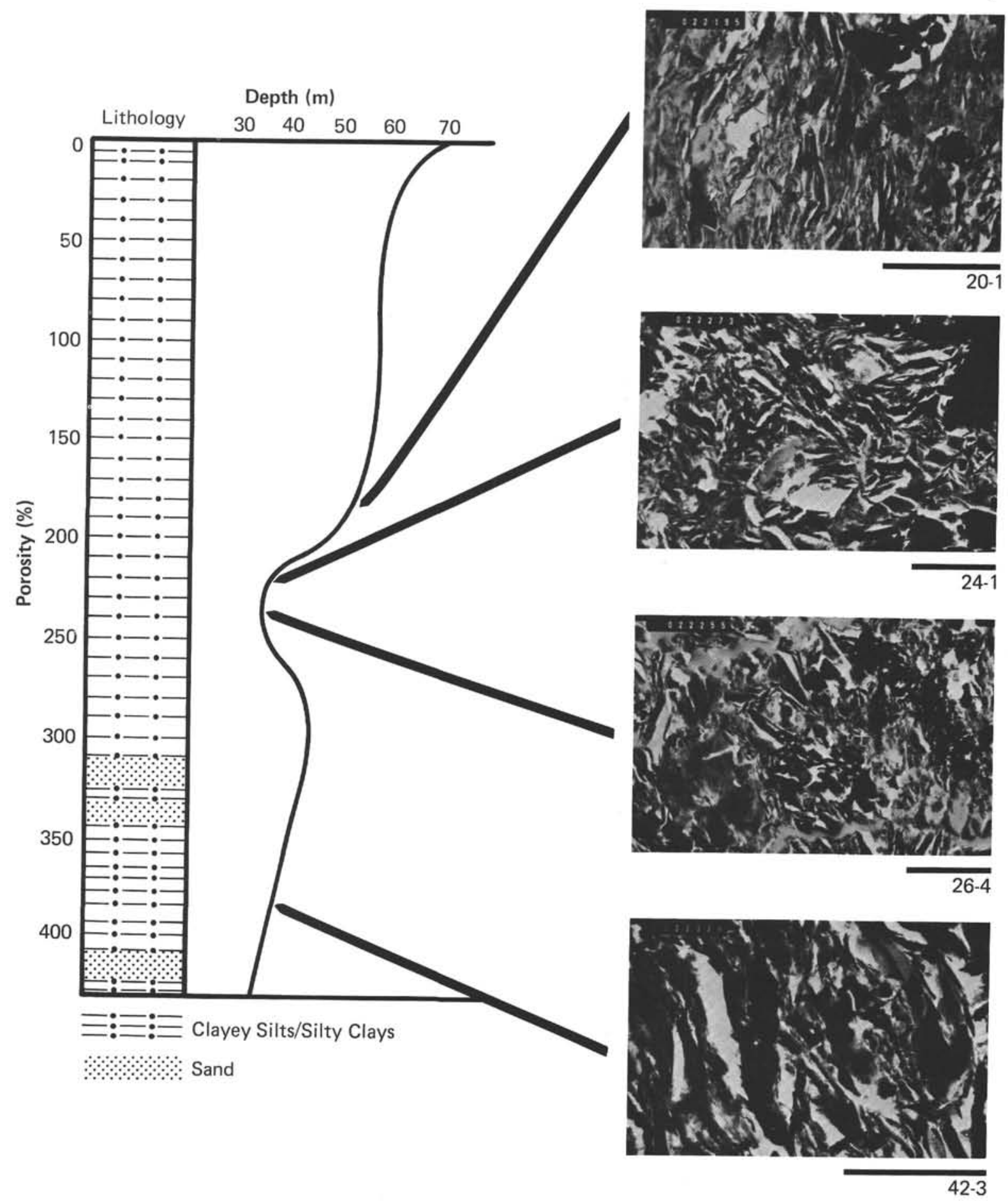

Figure 6. Transmission electron photomicrographs of ultrathin sections from Site 488 Samples 488-20-1, 488-24-1, 488-26-4, and 488-42-3 located above, within, and below the zone of deformation, respectively. Note high degree of preferential grain orientation in samples above and below zone and disrupted unoriented grain relationships from within zone of deformation. (Scale $\operatorname{bar}=1 \mu \mathrm{m}$.)

meters. Scatter in these profiles results from varying degrees of lithification, evident visually, and may be attributed to differences in the amount of carbonate precipitation within the voids and fluctuations in silt clay percentages.

Porosity and water content display similar trends, decreasing from $61 \%$ and $34 \%$ at 1.5 meters to $30 \%$ and
$13 \%$ at 285 meters, respectively. Bulk density increases from $1.70 \mathrm{Mg} / \mathrm{m}^{3}$ at 3.15 meters to $2.16 \mathrm{Mg} / \mathrm{m}^{3}$ at 289 meters and displays abundant scatter for the reasons just mentioned.

Compressional sound velocity increases from 1.60 $\mathrm{km} / \mathrm{s}$ at 12 meters to $1.90 \mathrm{~km} / \mathrm{s}$ at 237 meters. These values are variable with depth and appear lower than 


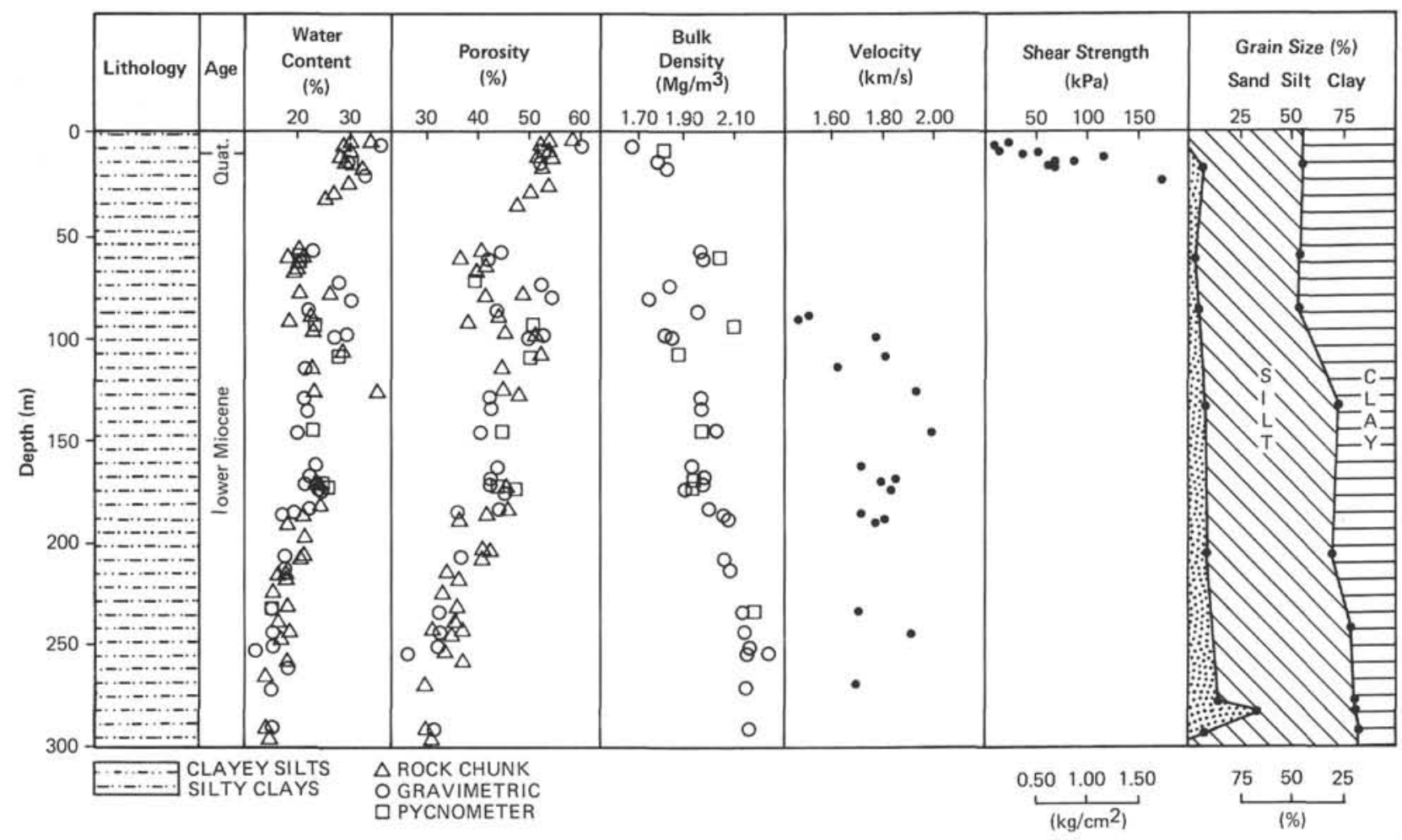

Figure 7. Geotechnical property summary profiles, Site 489.

those obtained from velocity analyses of multichannel seismic data $(2.0 \mathrm{~km} / \mathrm{s}$ average $)$.

Shear strength increases rapidly from $11.7 \mathrm{kPa}$ at 3.75 meters to $173.8 \mathrm{kPa}$ at 22 meters, below which failure by cracking precluded further measurements. $C_{u} \cdot P_{o}^{\prime-1}$ ratios computed using maximum values of shear strength at a particular depth exceed 1.0, suggesting these sediments are underconsolidated.

Two consolidation tests, performed on sediments obtained from 13.50 and 61.50 meters (Fig. 8; Table 3), show these sediments to be normally to overconsolidated. Overconsolidation ratios for these samples are 1.34 for $489 \mathrm{~A}-2-6(13.50 \mathrm{~m})$ and 1.03 for $489 \mathrm{~A}-4-4$ $(61.50 \mathrm{~m})$.

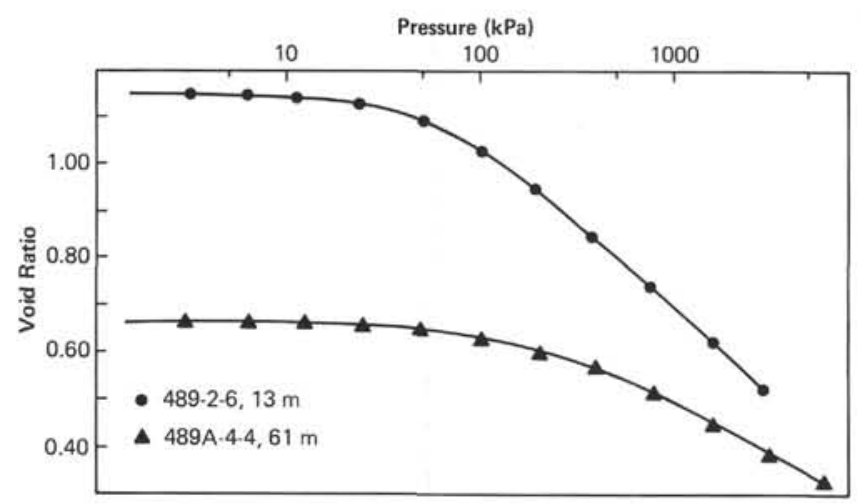

Figure 8. Void ratio versus logarithm of pressure curves $e$ - $\log P$ for Site 489 samples.

\section{Site 490}

Site 490 is located in the transition zone between continental crust and landward-dipping reflectors (Fig. 1). Drilling penetrated 142 meters of Quaternary clayey silts overlying $\mathbf{3 4 6}$ meters of Pliocene to upper Miocene silty clays. Geotechnical analyses (Fig. 9) show rapid changes in these properties from 0 to 50 meters, a gradual uniform change from 50 to 400 meters corresponding to the transformation from soft sediment to siltstone, and below 400 meters a small but significant change possibly reflecting an increase in deformation at this depth.

Porosity and water content decrease gradually from $68 \%$ to $48 \%$ at 2.3 meters to $35 \%$ and $16 \%$ at 540 meters, respectively. Bulk density increases from 1.53 $\mathrm{Mg} / \mathrm{m}^{3}$ at 2.3 meters to $2.11 \mathrm{Mg} / \mathrm{m}^{3}$ at 540 meters.

Compressional sound velocity measurements were limited to sediments cored below 350 meters because of attenuation due to gas. Those velocities measured range from $1.71 \mathrm{~km} / \mathrm{s}$ to maximum values of $1.88 \mathrm{~km} / \mathrm{s}$. These values agree very well with those derived from multichannel seismic reflection data, $1.81 \mathrm{~km} / \mathrm{s}$ (Shipley, this volume) and those expected on the basis of porosity velocity relationships developed by Nafe and Drake (1957).

Shear strength increases from $11.7 \mathrm{kPa}$ at 1.95 meters to $110 \mathrm{kPa}$ at 106.5 meters. Scatter in the shear strength profile results from premature failure by cracking, especially below 50 meters, and possible variations in disturbance. $C_{u} \cdot P_{o}^{\prime-1}$ ratios, computed using maximum shear strength values with depth, decrease gradually from 0.51 at 10 meters to 0.33 at 60 meters, indicating these sediments are normally consolidated. 
Table 3. Consolidation test results and geotechnical properties of samples tested from Site 489.

\begin{tabular}{ccccccccc}
\hline & $\begin{array}{c}\text { Depth below } \\
\text { Seafloor } \\
(\mathrm{m})\end{array}$ & $\begin{array}{c}\text { Bulk } \\
\text { Density } \\
\left(\mathrm{Mg} / \mathrm{m}^{3}\right)\end{array}$ & $\begin{array}{c}\text { Porosity } \\
(\%)\end{array}$ & $\begin{array}{c}\text { Water } \\
\text { Content } \\
(\%)\end{array}$ & $\begin{array}{c}\text { Void } \\
\text { Ratio }\end{array}$ & $\begin{array}{c}\text { Effective } \\
\text { Overburden } \\
\text { Pressure } \\
(\mathrm{kPa})\end{array}$ & $\begin{array}{c}\text { Preconsolidation } \\
\text { Pressure } \\
(\mathrm{kPa})\end{array}$ & $\begin{array}{c}\text { Overconsolidation } \\
\text { Ratio }\end{array}$ \\
\hline $\begin{array}{c}\text { Hole 489 } \\
2-6\end{array}$ & 13 & 1.82 & 53.80 & 30.70 & 1.17 & 97 & 130 & 1.34 \\
$\begin{array}{c}\text { Hole 489 } \\
4-4\end{array}$ & 61 & 2.05 & 39.58 & 19.22 & 0.66 & 520 & 507 & 1.03 \\
\hline
\end{tabular}

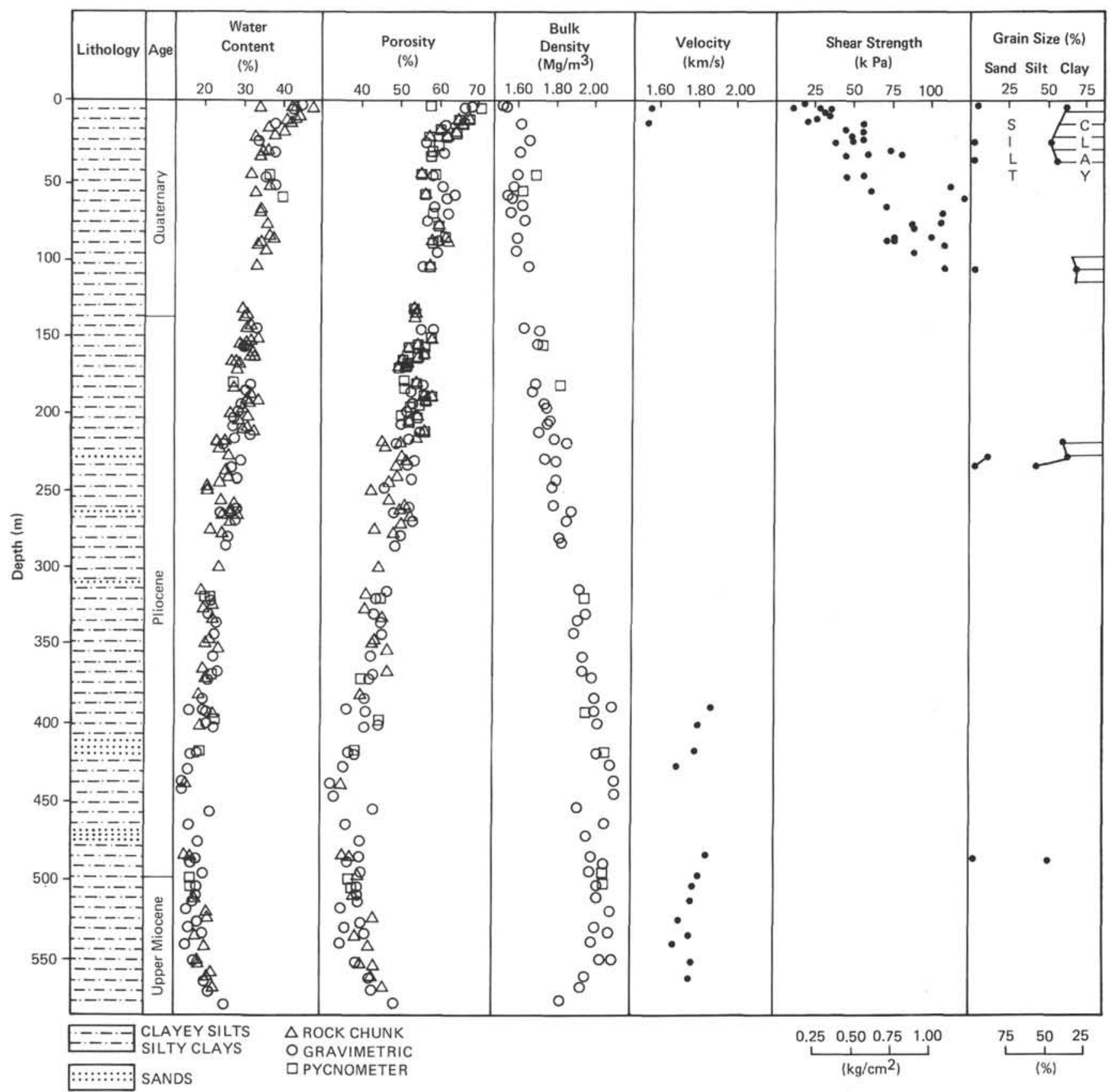

Figure 9. Geotechnical property summary profiles, Site 490. 


\section{Site 491}

Drilling in the middle trench inner slope (Fig. 1), Site 491 penetrated 542 meters of Quaternary and Pliocene silty clays. Geotechnical analyses (Fig. 10) reveal uniformly gradational changes to 410 meters sub-bottom, below which there is an apparent increase in the amount of induration. Attenuation due to gas prevented compressional sound velocity measurements.

Porosity and water content decrease from $66 \%$ and $44 \%$ at 0.50 meters to $33 \%$ and $15 \%$ at 525 meters, respectively. Both porosity and water content decrease more rapidly below 410 meters. Bulk density increases from $1.58 \mathrm{Mg} / \mathrm{m}^{3}$ at 6.60 meters to $2.07 \mathrm{Mg} / \mathrm{m}^{3}$ at 520 meters. This break in geotechnical properties below 410 meters corresponds approximately to lithologic Unit 3, a zone of increasing sand content with depth, implying that some of this change results from lithologic variation.

Shear strength increases regularly from $13.5 \mathrm{kPa}$ at 0.50 meters to $122.5 \mathrm{kPa}$ at 69 meters. $C_{u} \cdot P_{o}^{\prime-1}$ ratios average 0.27 to a depth of 70 meters, suggesting these sediments fall within the range of values suggested by Skempton $(0.2-0.5,1970)$ for normally consolidated sediments.

Four consolidation tests performed on Site 491 sediments (Fig. 11; Table 4) indicate Samples 491-2-4 $(15.50 \mathrm{~m})$ and $491-6-3(52.00 \mathrm{~m})$ are normally to slightly overconsolidated (OCR $=1.32$ and 0.99 , respectively), whereas Samples 491-17-5 (150.50 m) and 491-25-5

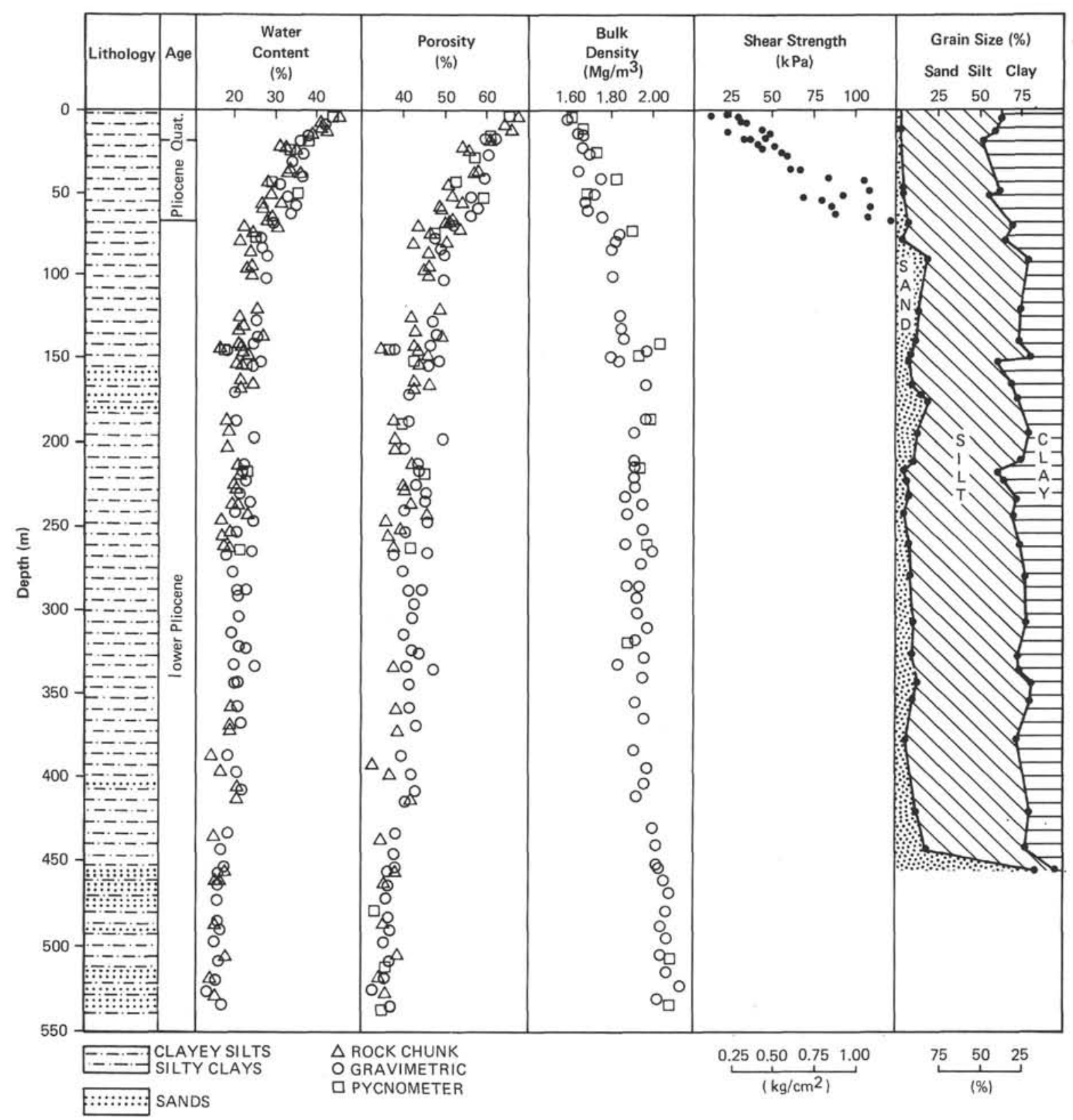

Figure 10. Geotechnical property summary profiles, Site 491 . 


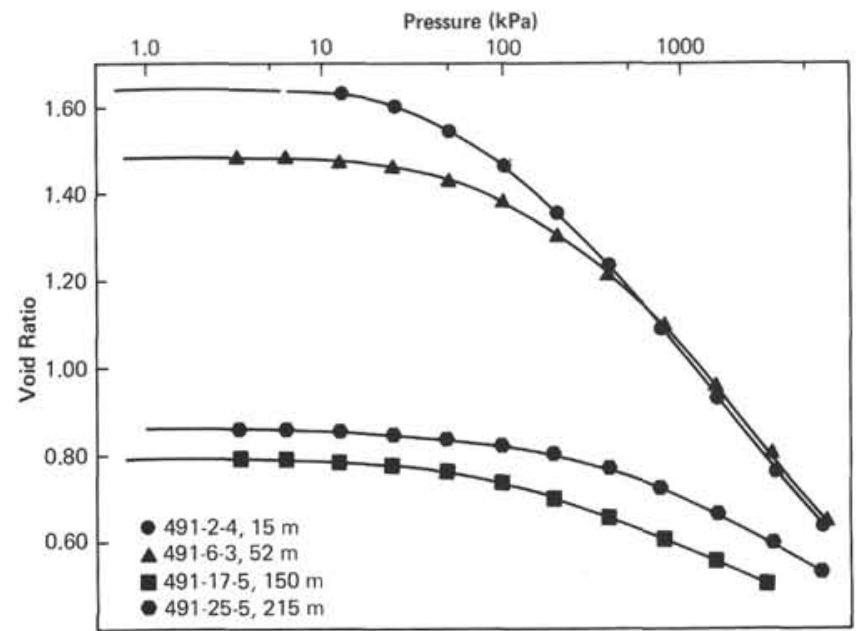

Figure 11. Void ratio versus logarithm of pressure curves $e$ - $\log P$ for Site 491 samples.

$(215.50 \mathrm{~m})$ are underconsolidated $(\mathrm{OCR}=0.13$ and 0.39 , respectively). Test results from the two shallowest samples agree very well with the consolidation state predicted on the basis of shear strength. Overconsolidation ratios for the deeper samples are within the range of OCR values developed from test results on underconsolidated Site 488 samples.

\section{Site 492}

Drilling at Site 492 , located seaward of the trench slope break on the trench inner slope (Fig. 1), penetrated 247 meters of Quaternary to upper Miocene clayey silts overlying 43 meters of Miocene clayey silts interbedded with sand. Sands varied in thickness from less than 1 meter to several meters. General geotechnical results (Fig. 12) from Site 492, Holes 492, 492A, and 492B, will be discussed jointly. In addition, a comparison of results utilizing standard rotary and hydraulic piston cores will be presented.

Gas expansion and related core disturbance greatly influenced the index properties of Hole 492 sediments, particularly between 125 and 200 meters. Signal attenuation due to gas precluded compressional sound velocity measurements. Porosity decreases from $66 \%$ at 8.0 meters to $49 \%$ at 110 meters, below which porosity increases to $54 \%$ at 160 meters, then decreases to a minimum of $34 \%$ at 286 meters. Water content decreases from $35 \%$ at 0.50 meters to $26 \%$ at 110 meters. Below
110 meters water content increases to $32 \%$ at 150 meters, then decreases to $18 \%$ at 286 meters. Bulk density displays the inverse trend, gradually increasing from $1.57 \mathrm{Mg} / \mathrm{m}^{3}$ to $1.86 \mathrm{Mg} / \mathrm{m}^{3}$ at 80 meters and 110 meters, respectively. Bulk density then decreases to $1.74 \mathrm{Mg} / \mathrm{m}^{3}$ at 160 meters and finally increases to a maximum of $1.96 \mathrm{Mg} / \mathrm{m}^{3}$ at 286 meters.

Shear strength increases from $5.9 \mathrm{kPa}$ at 1.40 meters to a maximum of $119.6 \mathrm{kPa}$ at 48 meters (Fig. 13). Scatter in this profile results from variations in drilling disturbance and in silt clay ratios. $C_{u} \cdot P_{o}^{\prime-1}$ ratios, determined using a best fit line through Site 492 shear strength data, increase gradually from 0.65 at 10 meters to 0.85 at 40 meters. These values indicate sediments in the upper 40 meters to be normal to overconsolidated using the range of values presented by Skempton (1970).

Sixteen consolidation tests performed on Site 492 sediments (Figs. 14, 15, 16; Table 5) show normal to overconsolidated sediments in the upper 135 meters, below which test results indicate underconsolidation. Overconsolidation ratios for all of Hole 492A samples are greater than 2.0 and increase with depth to a maximum of 6.20 at 26 meters. Ratios determined for Hole 492 samples within the upper 30 meters vary between 1.67 and 2.77 and also indicate overconsolidated sediments. Below 30 meters, however, OCR values vary from 0.303 at 36.50 meters to 5.304 at 104.50 meters. Deeper samples, 492-26-5 and 492-30-1 (239.00 $\mathrm{m}$ and 266.50 $\mathrm{m}$, respectively), are very underconsolidated with OCR values of 0.20 and 0.08 , respectively.

Comparison of bulk property results from Holes 492 and 492A (Fig. 13) reveals only subtle variations in porosity, water content, and bulk density between rotary drilled and hydraulic piston cored samples. Although visual observations of these cores failed to resolve any increase in disturbance due to the rotary drilling technique, shear strength measurements revealed interesting differences between samples at similar depths obtained by both coring techniques. Shear strengths of rotary drilled samples display much more scatter, particularly below 20 meters, than do the samples obtained with the hydraulic piston corer. This suggests that, although disturbance caused by rotary drilling may not be visually evident in relatively high shear strength sediments, it nevertheless causes partial remolding and a decrease in cohesion. OCR values are significantly higher for hydraulic piston cored samples than for rotary drilled samples; this also suggests partial remold-

Table 4. Consolidation test results and geotechnical properties of samples tested from Site 491.

\begin{tabular}{ccccccccc}
\hline & $\begin{array}{c}\text { Depth below } \\
\text { Seafloor } \\
(\mathrm{m})\end{array}$ & $\begin{array}{c}\text { Bulk } \\
\text { Density } \\
\left(\mathrm{Mg} / \mathrm{m}^{3}\right)\end{array}$ & $\begin{array}{c}\text { Porosity } \\
(\%)\end{array}$ & $\begin{array}{c}\text { Water } \\
\text { Content } \\
(\%)\end{array}$ & $\begin{array}{c}\text { Void } \\
\text { Ratio }\end{array}$ & $\begin{array}{c}\text { Effective } \\
\text { Overburden } \\
\text { Pressure } \\
(\mathrm{kPa})\end{array}$ & $\begin{array}{c}\text { Preconsolidation } \\
\text { Pressure } \\
(\mathrm{kPa})\end{array}$ & $\begin{array}{c}\text { Overconsolidation } \\
\text { Ratio }\end{array}$ \\
\hline Hole 491 & & & & & & & & \\
$2-4$ & 15 & 1.65 & 61.40 & 37.46 & 1.59 & 91 & 120 & 1.32 \\
$6-3$ & 52 & 1.69 & 58.55 & 35.42 & 1.41 & 355 & 350 & 0.99 \\
$17-5$ & 150 & 1.93 & 43.69 & 22.90 & 0.78 & 1189 & 150 & 0.13 \\
$22-5$ & 215 & 1.93 & 45.45 & 23.72 & 0.83 & 1789 & 700 & 0.39 \\
\hline
\end{tabular}




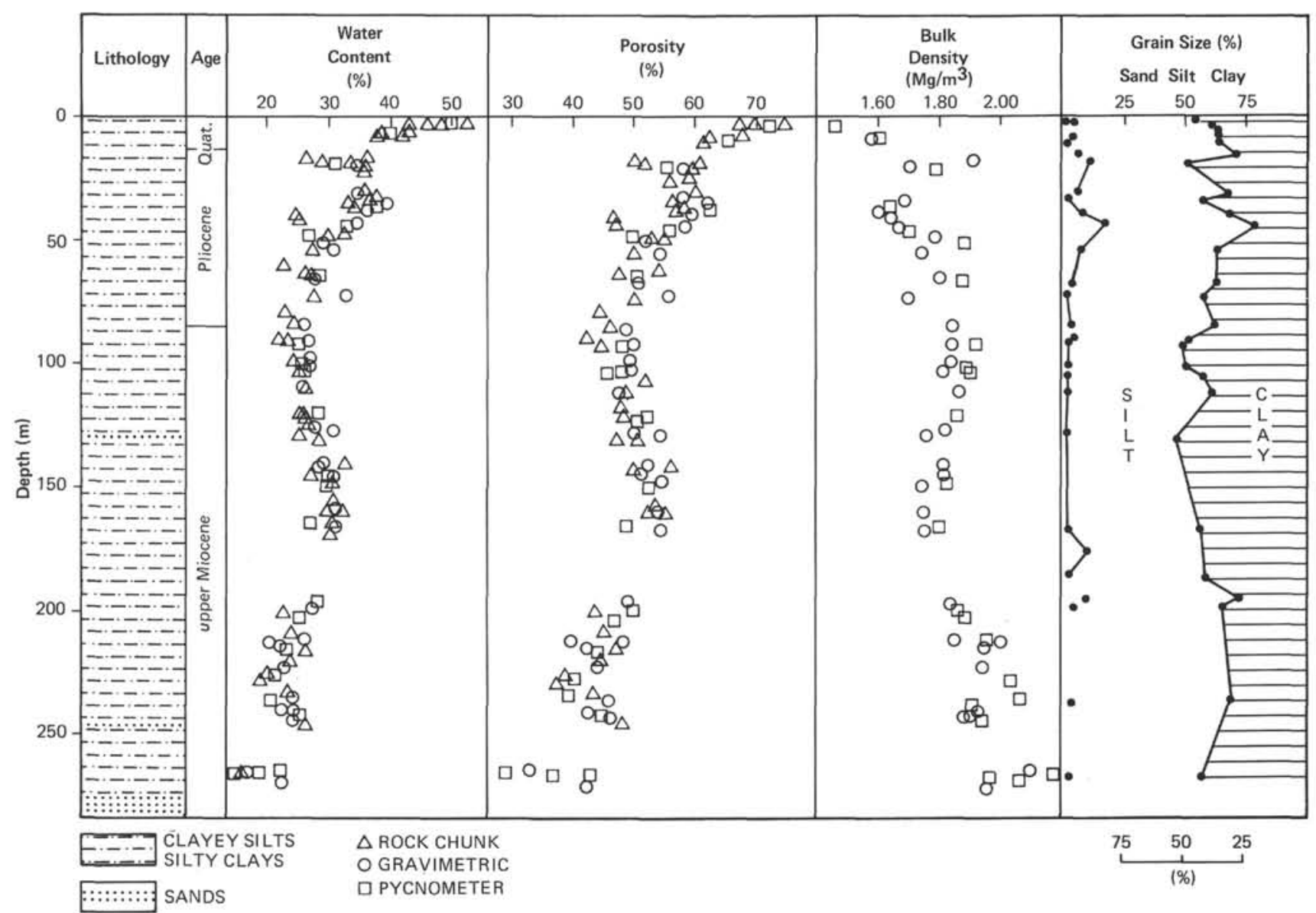

Figure 12. Geotechnical property summary profiles, Site 492 .

ing, possibly on a grain-to-grain scale, which may be evident in clay fabric and transmission electron microscopy techniques.

Shear strength and consolidation test results indicate the value of the hydraulic piston corer to any detailed geotechnical program. In sediments where shear strengths are more typical of normal or underconsolidated sediments $(<100 \mathrm{kPa})$ at depth, differences in geotechnical properties may be even more substantial.

Problems with the hydraulic piston corer did occur, however, when shear strengths exceeded $75 \mathrm{kPa}$. "Flow in" evident as smeared vertical laminations as well as collapsed core liners resulted in low recovery of good quality sediment, severely limiting the usefulness of the corer.

\section{Site 493}

Site 493, the most landward of all sites drilled (Fig. 1), penetrated 50 meters of Quaternary clayey silts, overlying 310 meters of Pliocene and Miocene clayey silts grading into 287 meters of lower Miocene silty sands. This overall transgressive sequence displays a gradual change in geotechnical properties with depth (Fig. 17).

Porosity decreases gradually from $62.5 \%$ at 40 meters to $48 \%$ at 360 meters. Between 360 and 365 meters a $5 \%$ decrease in porosity to $43 \%$ occurs. Below 365 meters porosity gradually decreases to $32 \%$ at 570 meters. Scatter in the porosity depth profile results from variations in sand-silt-clay ratios, gas expansion, and sediment spalling during volume measurements. Water content displays a similar trend, decreasing from $44 \%$ at 43 meters to $27 \%$ at $360 \mathrm{~m}$. From 360 to 435 meters water content remains relatively constant $-24 \%$ - then decreases between 435 and 579 meters to $19 \%$. Bulk density is variable in the upper 365 meters, increasing from $1.60 \mathrm{Mg} / \mathrm{m}^{3}$ at 40 meters to $1.79 \mathrm{Mg} / \mathrm{m}^{3}$ at 360 meters. Below 360 meters density abruptly increases, to $1.95 \mathrm{Mg} / \mathrm{m}^{3}$ at 365 meters, then gradually continues to increase, to $2.10 \mathrm{Mg} / \mathrm{m}^{3}$ at 465 meters. Below 465 meters bulk density remains relatively constant, averaging $2.07 \mathrm{Mg} / \mathrm{m}^{3}$. Significant changes in porosity and bulk density occur between 360 and 365 meters. These changes correspond directly with a Miocene unconformity at this depth, which probably represents an erosional rather than a nondepositional event.

Shear strength increased from $17 \mathrm{kPa}$ at 12.45 meters to $121 \mathrm{kPa}$ at 127 meters. Scatter in the shear strength profile results from variations in silt-clay ratios and core disturbance. $C_{u} \cdot P_{o}^{\prime-1}$ ratios determined using maximum shear strengths for a particular depth average 0.20 , which is the lower limit of the range of values given by Skempton (1970) for normally consolidated clays.

Three consolidation tests show these sediments are underconsolidated (Fig. 18; Table 6), with OCR values falling within the range of those from other sites. 


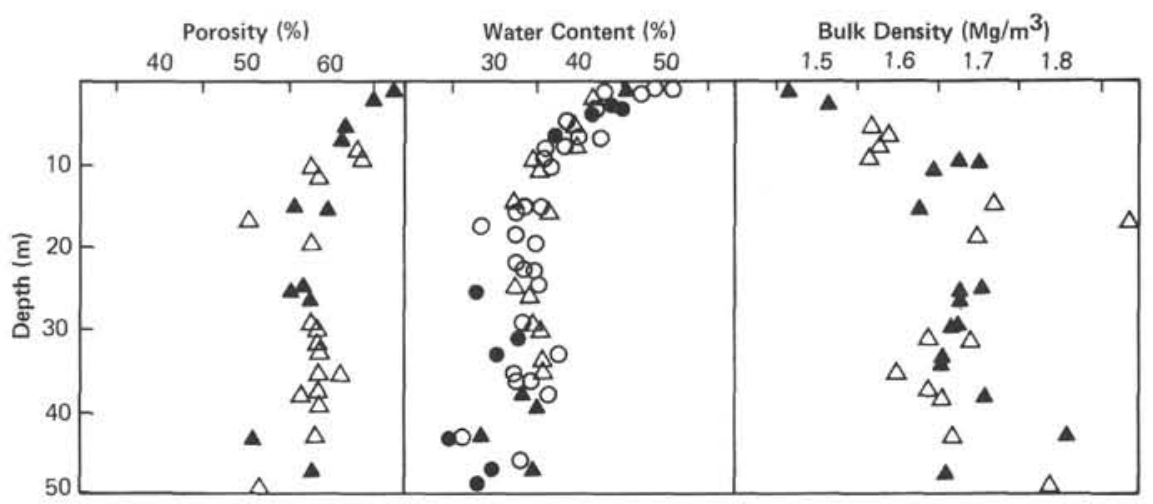

A PISTON CORE GRAVIMETRIC

- PISTON CORE CHUNK

$\triangle$ ROTARY DRILLING GRAVIMETRIC

OROTARY DRILLING CHUNK

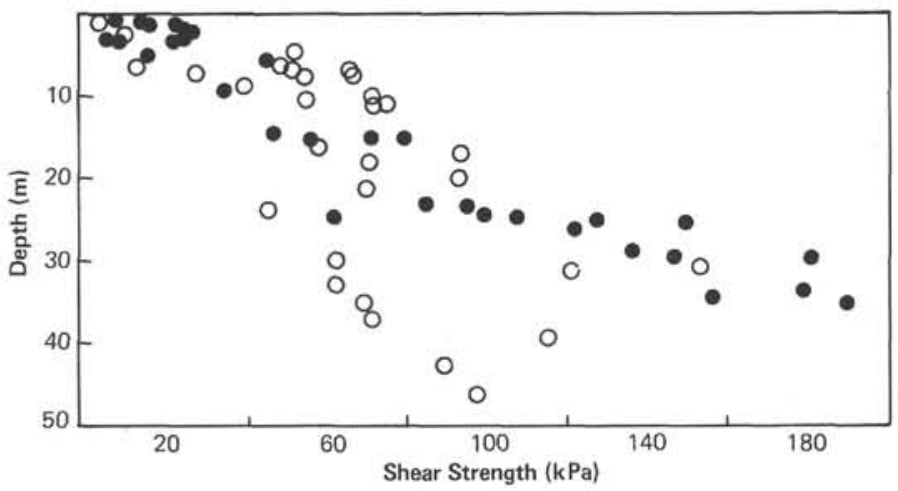

- VANE SHEAR PISTON CORE

OVANE SHEAR ROTARY CORE

Figure 13. Geotechnical property profiles comparing sediments cored by rotary drilling and hydraulic piston corer techniques. Note similarity in index property trends with depth and increased scatter in sediment shear strengths from rotary drilled samples.
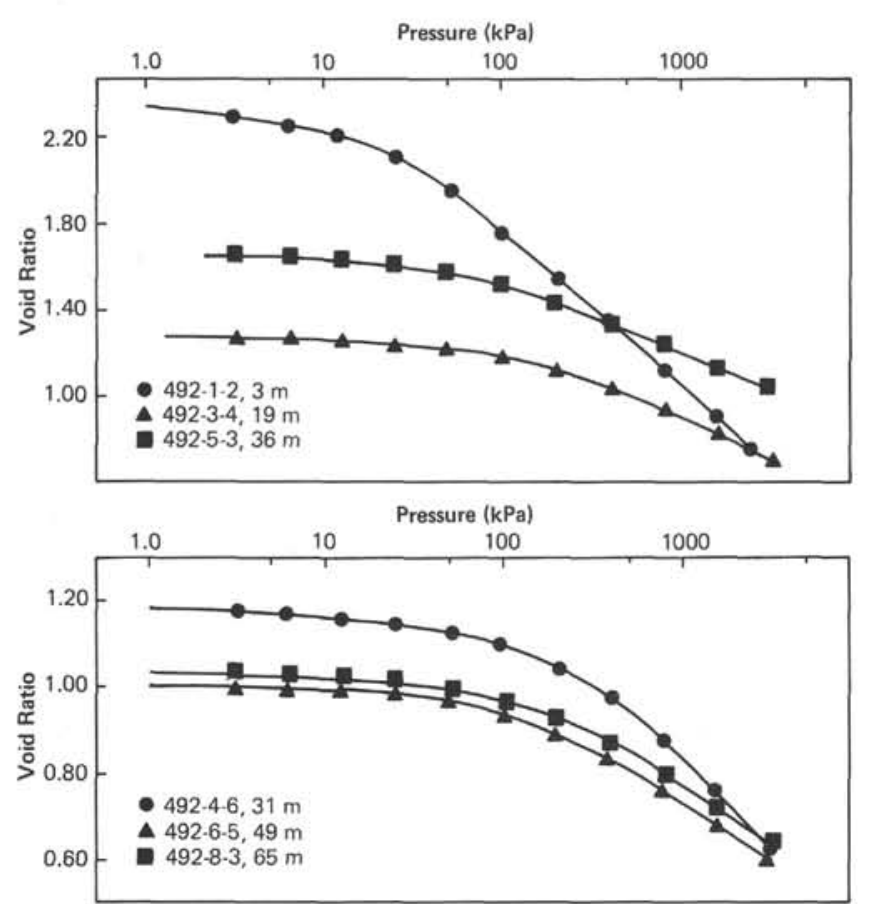

Figure 14. Void ratio versus logarithm of pressure curves $e-\log P$ for Samples 492-1-2, 492-3-4, 492-4-6, 492-5-3, 492-6-5, and 492-8-3.
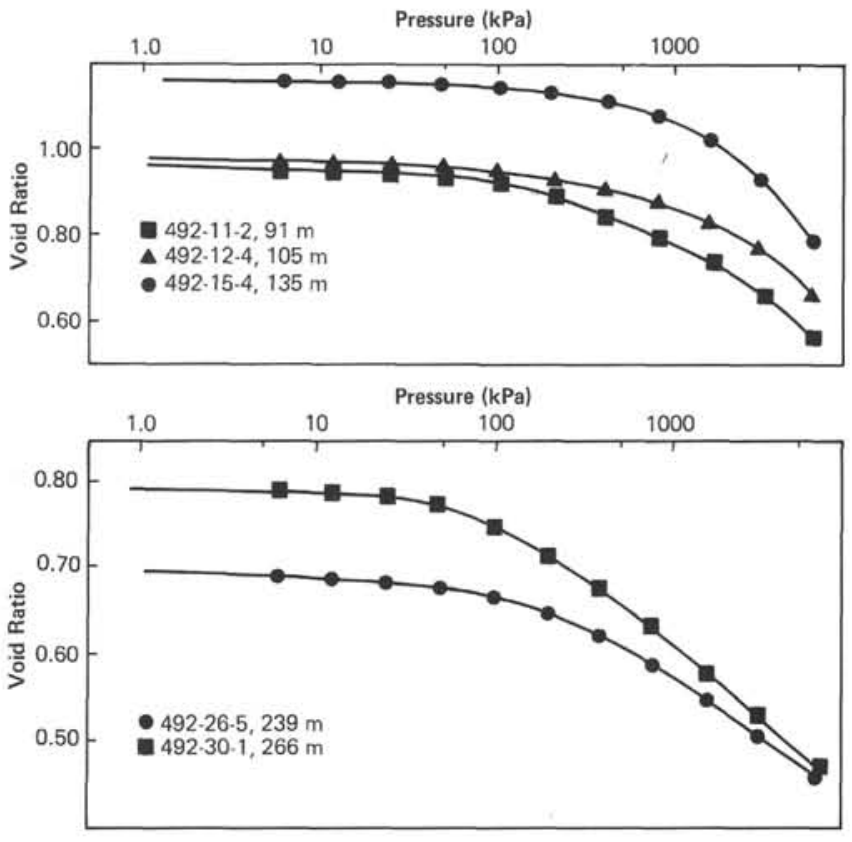

Figure 15. Void ratio versus logarithm of pressure curves $e-\log P$ for Samples 492-11-2, 492-12-4, 492-15-4, 492-26-5, and 492-30-1. 

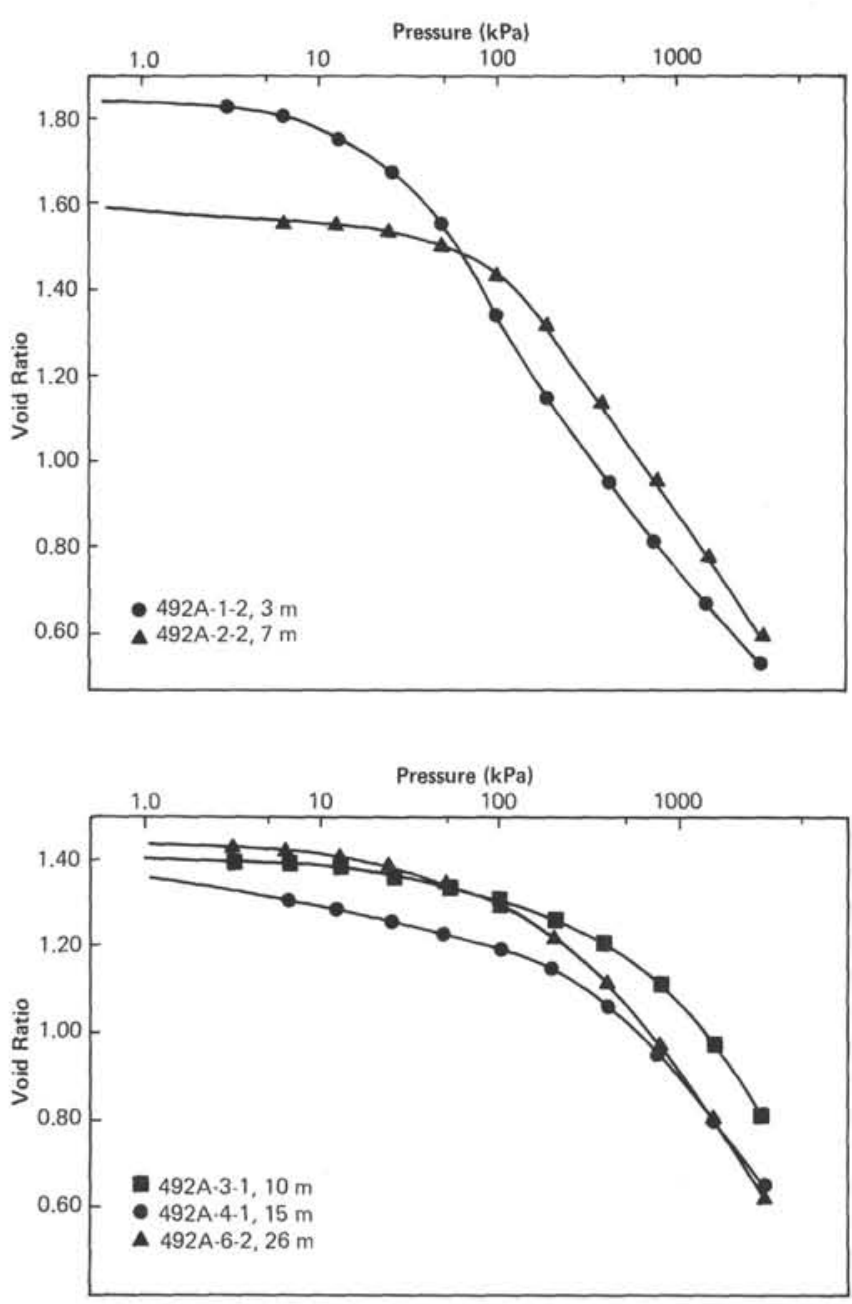

Figure 16. Void ratio versus logarithm of pressure curves $e$ - $\log P$ for Hole 492A samples.

\section{DISCUSSION}

The state of consolidation of Middle America Trench sediments appears quite variable. Consolidation test results indicate that sediments tested at Sites 487,488 , and 493 are underconsolidated, whereas sediments tested at Sites 489 and 492 are normal to overconsolidated. Normally consolidated near-surface sediments from Site 491 become underconsolidated with increasing depth.

Underconsolidated sediments result from factors which decrease the effective stress by creating excess porewater pressures. Mechanisms resulting in underconsolidation include (1) rapid sediment accumulation rates, (2) low sediment permeability relative to the length of the drainage path, (3) laterally applied stresses, (4) artesian water pressure or induced water pressure from deeper formations, (5) high concentrations of gas in sediments, and (6) physicochemical interparticle bonding and cementation. Sample disturbance may decrease the preconsolidation pressure sufficiently to result in "apparent" underconsolidation.
Site 487 geotechnical properties display only subtle changes with increasing depth of burial. This indicates that limited dewatering occurs in response to accumulating overburden after initial deposition. Slow accumulation of pelagic clays may result in the development of cohesive interparticle bonds (Hamilton, 1964) which inhibit dewatering resulting in underconsolidated, high porosity, low bulk density sediments at depth.

The response of these high water content sediments ( $>50 \%$ water by weight) to the rapidly applied overburden as they descend the outer trench slope and under the lower trench inner slope may have important implications concerning lower slope deformation and accretionsubduction processes. In laboratory one-dimensional consolidation tests the sediment structure of pelagic clays readily collapses under a critical load (Mitchell, 1976). This collapse results in a well-defined break in slope on the $e-\log P$ curve which is best illustrated on the $e$-log $P$ curve of Sample 487-14-3 (Fig. 2). Although greatly simplified, a similar response occurring while these sediments are descending under the lower trench inner slope could release large quantities of water, thereby causing abnormal pressures. Conversely, if the pelagic sediment structure does not collapse under some critical overburden pressure the pelagic sediment should become abnormally pressured. In areas of high convergence rates, these sediments would be carried into the subduction zone and rapidly loaded under an existing overburden at a rate which may not allow dissipation of excess porewater pressures. Increased deformation within the lower trench slope could result from either mechanism.

Underconsolidated Site 488 sediments accumulated at rates in excess of $380 \mathrm{~m} / \mathrm{m}$.y. in the upper 210 meters sub-bottom, below which accumulation rates exceeded $200 \mathrm{~m} / \mathrm{m} . \mathrm{y}$. When these values are corrected for compaction they exceed $500 \mathrm{~m} / \mathrm{m} . \mathrm{y}$. (Shephard and MacMillan, this volume) and are of sufficient magnitude to cause underconsolidation where permeabilities are less than $10^{-7} \mathrm{~cm} / \mathrm{s}$ (Bredehoft and Hanshaw, 1968). Permeabilities of Site 488 sediments fall within the range of $10^{-7} \mathrm{~cm} / \mathrm{s}$ to $10^{-9} \mathrm{~cm} / \mathrm{s}$. Excess pore pressures in subduction complexes have been attributed to laterally applied stresses (Hottman and Smith, 1978). Folding and faulting of lower slope and trench sediments, evident on high resolution and multichannel seismic profiles near Site 488 , indicate lateral stresses may be very important in this region. Induced pore pressures from deeper formations may also contribute to the state of underconsolidation. $E$-log $P$ curves of closely spaced samples from different cores at Site 488 (cf. Samples 488-18-5 and 488-19-1, and Samples 488-30-1 and 488-33-6, Fig. $5)$ show many similar characteristics. This improves the reliability of the test results and indicates these results are indicative of in situ conditions.

Hamilton (1964) suggests that any factor or combination of factors which result in unusual sediment strength will produce the effect of overconsolidation. Factors most important to this investigation include (1) slow rates of sediment accumulation, (2) removal of previ- 
Table 5. Consolidation test results and geotechnical properties of samples tested from Site 492 .

\begin{tabular}{|c|c|c|c|c|c|c|c|c|}
\hline Core/Section & $\begin{array}{l}\text { Depth below } \\
\text { Seafloor } \\
\text { (m) }\end{array}$ & $\begin{array}{c}\text { Bulk } \\
\text { Density } \\
\left(\mathrm{Mg} / \mathrm{m}^{3}\right)\end{array}$ & $\begin{array}{c}\text { Porosity } \\
(\%)\end{array}$ & $\begin{array}{c}\text { Water } \\
\text { Content } \\
(\%)\end{array}$ & $\begin{array}{l}\text { Void } \\
\text { Ratio }\end{array}$ & $\begin{array}{l}\text { Effective } \\
\text { Overburden } \\
\text { Pressure } \\
\text { (kPa) }\end{array}$ & $\begin{array}{c}\text { Preconsolidation } \\
\text { Pressure } \\
(\mathrm{kPa})\end{array}$ & $\begin{array}{c}\text { Overconsolidation } \\
\text { Ratio }\end{array}$ \\
\hline \multicolumn{9}{|l|}{ Hole 492} \\
\hline $1-2$ & 3 & 1.46 & 72.04 & 50.20 & 2.58 & 16 & 35 & 2.23 \\
\hline $3-4$ & 19 & 1.79 & 55.76 & 31.40 & 1.26 & 179 & 300 & 1.67 \\
\hline $4-6$ & 31 & 1.73 & 57.20 & 33.70 & 1.34 & 199 & 550 & 2.77 \\
\hline $5-3$ & 36 & 1.64 & 62.23 & 37.03 & 1.65 & 231 & 90 & 0.39 \\
\hline $6-5$ & 49 & 1.89 & 49.18 & 26.90 & 0.97 & 319 & 160 & 0.50 \\
\hline $8-3$ & 65 & 1.88 & 50.37 & 28.50 & 1.02 & 439 & 280 & 0.64 \\
\hline $11-2$ & 91 & 1.92 & 47.43 & 25.14 & 0.90 & 640 & 300 & 0.47 \\
\hline $12-4$ & 105 & 1.90 & 47.50 & 25.94 & 0.91 & 754 & 4000 & 5.30 \\
\hline $15-4$ & 135 & 1.80 & 53.50 & 30.51 & 1.15 & 1002 & 2100 & 2.10 \\
\hline $26-5$ & 239 & 2.06 & 39.00 & 20.00 & 0.64 & 1777 & 180 & 0.09 \\
\hline $30-1$ & 266 & 1.98 & 42.82 & 21.60 & 0.75 & 2041 & 350 & 0.20 \\
\hline \multicolumn{9}{|l|}{ Hole $492 \mathrm{~A}$} \\
\hline $1-2$ & 3 & 1.55 & 67.21 & 44.54 & 2.05 & 16 & 35 & 2.23 \\
\hline $2-2$ & 7 & 1.61 & 63.82 & 40.40 & 1.76 & 39 & 140 & 3.60 \\
\hline $3-1$ & 10 & 1.64 & 61.73 & 38.30 & 1.61 & 60 & 300 & 5.00 \\
\hline $4-1$ & 15 & 1.73 & 59.41 & 35.53 & 1.46 & 92 & 420 & 4.57 \\
\hline $6-2$ & 26 & 1.72 & 57.81 & 34.85 & 1.37 & 171 & 1060 & 6.22 \\
\hline
\end{tabular}

ously applied overburden by gravity driven mass movement mechanisms, (3) great age, and (4) tectonic induced overpressures. In addition, near-surface sediments (Sample 488-2-3, $4.0 \mathrm{~m}$ ) may display an "apparent" overconsolidation owing to interparticle cohesion at the time of deposition being greater than the pressure resulting from accumulated overburden.

Overconsolidation ratios slightly in excess of 1.0 and $C_{u} \cdot P_{o}^{\prime-1}$ ratios of 1.0 indicate Site 489 Miocene sediments are overconsolidated, although the exact cause and degree of overconsolidation is unclear. A MioceneQuaternary unconformity penetrated at this site is interpreted as an erosional rather than nondepositional event on the basis of seismic reflection data (see Site 489 summary; this volume). Regression analysis of the shear strength depth profile $\left(Z=0.103 C_{u}+2.73\right.$; correlation coefficient 0.898 ), however, indicates the removal of only 3 to 5 meters of overburden, corroborating the consolidation test results. This would not be sufficient to result in truncated and chaotic reflector configurations suggestive of an erosional unconformity. $C_{u} \cdot P_{o}^{\prime-1}$ values greater than the range suggested by Skempton (1970) for normally consolidated sediments may result from slow sediment accumulation rates $(<30 \mathrm{~m} / \mathrm{m} . \mathrm{y}$.) in conjunction with development of interparticle bonding causing high shear strength at shallow depth.

Several factors may have contributed to the overconsolidated state $(O C R \geq 1.0)$ of Site 492 sediments. This site is located just seaward of the trench slope break, a region actively upbuilding, where deposition and subsequent removal of overburden resulting in overconsolidation are possible. Sands penetrated at the base of Hole 492B indicate original deposition within the trench or lowermost slope where deformation is actively occurring. Low sediment accumulation rates $(<40 \mathrm{~m} / \mathrm{m}$.y.) and the age (Miocene) of these sediments at shallow depths could also result in overconsolidation. Sediments having OCR values of less than 1 may have been sub- jected to increased mechanical or gas-related disturbance not evident visually or by radiography.

Site 491 sediments are normally consolidated to a maximum depth of 50 meters, below which they become underconsolidated. Sedimentation rates in the upper 70 meters are very low ( $<45 \mathrm{~m} / \mathrm{m}$.y.) but increase to an average of greater than $900 \mathrm{~m} / \mathrm{m}$.y. (uncorrected for compaction) below 150 meters. These extremely high rates of sediment accumulation at depth are responsible for the underconsolidation of the deeper sediments.

Bulk property results indicate that in spite of extreme sedimentation rates Site 491 sediments have dewatered sufficiently to result in porosities approximately equal to those of sediments penetrated at similar depths at Sites 488 and 492 . Tectonic-related deformation and dewatering may be partially responsible for these low bulk property values.

\section{EFFECTS OF CONVERGENCE ON GEOTECHNICAL PROPERTIES}

Prior to the transect of holes drilled along the Japan Trench margin, only single DSDP sites from select trench inner slope convergent margins had been drilled. Using this data (Lee et al., 1973; Bouma and Moore, 1975; Trabant et al., 1975; and Moore and Karig, 1976) and data from the Washington continental margin (Silver, 1972; Carson et al., 1974; Carson, 1977), a general model for convergent margin sediment geotechnical properties was developed. This model suggests that lower trench inner slope sediments are rapidly deformed and dewatered, resulting in highly overconsolidated sediments at shallow depths. The amount of deformation and the rate of change in geotechnical properties presumably decreases upslope away from the toe of the lower trench inner slope. Japan Trench margin drilling, however, recovered sediments with anomalous properties compared to those from previously drilled margins. Carson and Bruns (1980) report porosity values of 


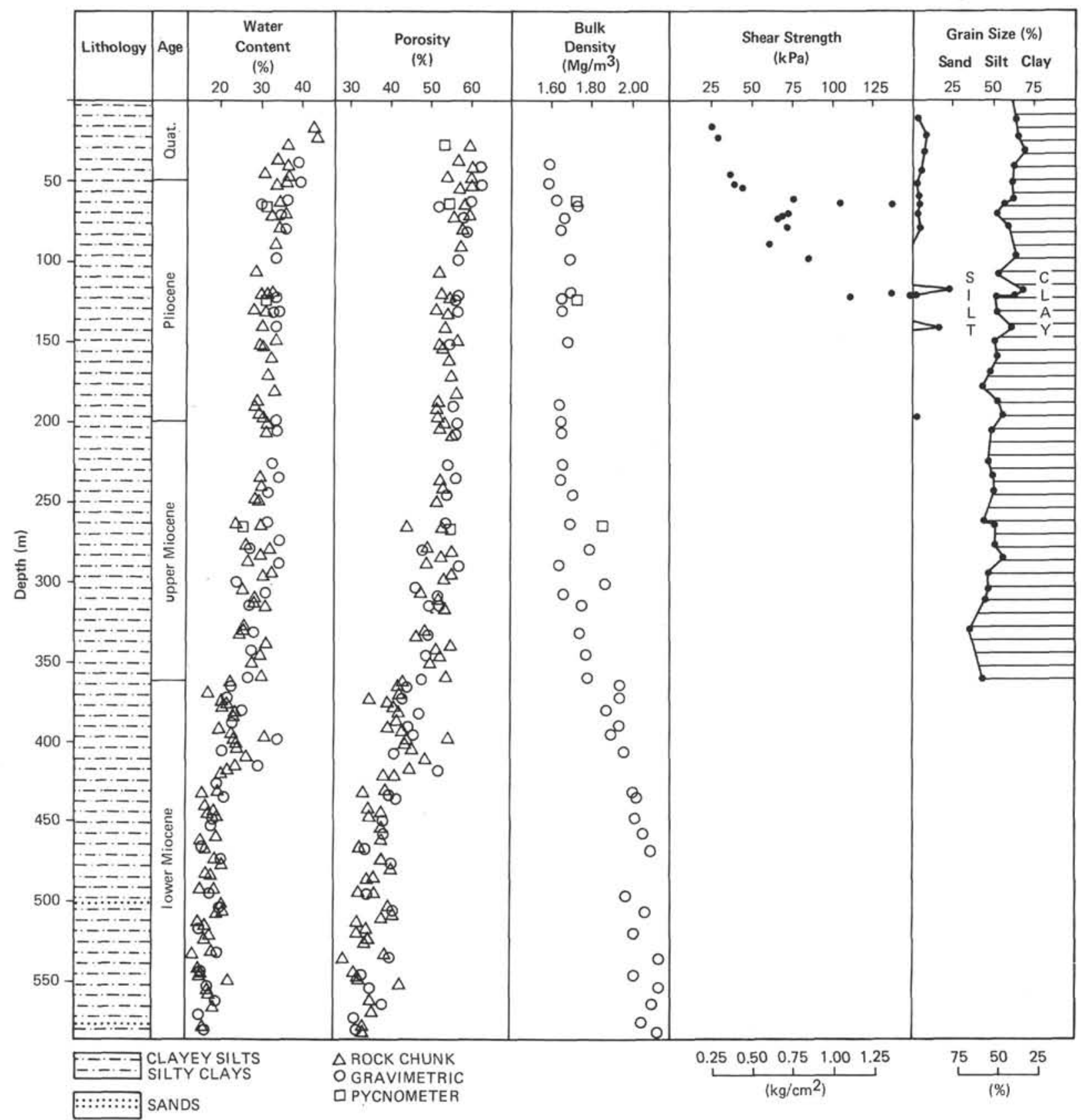

Figure 17. Geotechnical property summary profiles, Site 493.

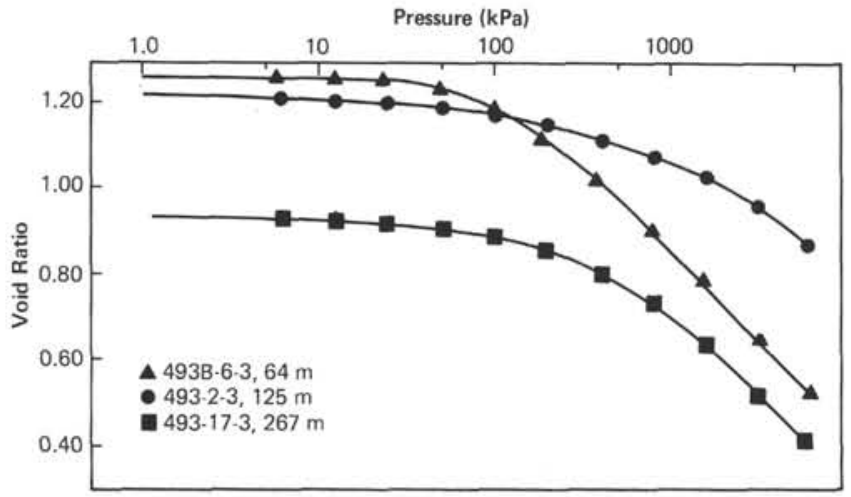

Figure 18. Void ratio versus logarithm of pressure cuves $e-\log P$ for Site 493 samples. lower trench inner slope Site 441 sediments which exceed $60 \%$ at 550 meters sub-bottom. They indicate that the geotechnical property data from the Japan lower trench inner slope is representative of thick, overpressured, underconsolidated sediments. This interpretation agrees very well with Japan Trench Site 440 consolidation test results, which show underconsolidated sediments becoming increasingly more underconsolidated with depth (Shephard and Bryant, 1980).

Middle America Trench geotechnical properties appear somewhat anomalous also, in that values of porosity, bulk density, and water content are consistent with those determined from previously drilled convergent margin sites (Fig. 19), but the consolidation characteristics are much different. Lower trench inner slope 
Table 6. Consolidation test results and geotechnical properties of samples tested from Site 493.

\begin{tabular}{ccccccccc}
\hline & $\begin{array}{c}\text { Depth below } \\
\text { Seafloor } \\
(\mathrm{m})\end{array}$ & $\begin{array}{c}\text { Bulk } \\
\text { Density } \\
\left(\mathrm{Mg} / \mathrm{m}^{3}\right)\end{array}$ & $\begin{array}{c}\text { Porosity } \\
(\%)\end{array}$ & $\begin{array}{c}\text { Water } \\
\text { Content } \\
(\%)\end{array}$ & $\begin{array}{c}\text { Void } \\
\text { Ratio }\end{array}$ & $\begin{array}{c}\text { Effective } \\
\text { Overburden } \\
\text { Pressure } \\
(\mathrm{kPa})\end{array}$ & $\begin{array}{c}\text { Preconsolidation } \\
\text { Pressure } \\
(\mathrm{kPa})\end{array}$ & $\begin{array}{c}\text { Overconsolidation } \\
\text { Ratio }\end{array}$ \\
\hline $\begin{array}{c}\text { Hole 493B } \\
6-3\end{array}$ & 64 & 1.74 & 55.04 & 33.13 & 1.22 & 383 & 170 & 0.44 \\
Hole 493 & & & & & & & & \\
$2-3$ & 125 & 1.74 & 53.52 & 31.15 & 1.15 & 983 & 250 & 0.26 \\
$17-3$ & 267 & 1.87 & 46.56 & 25.32 & 0.87 & 1728 & 600 & 0.35 \\
\hline
\end{tabular}

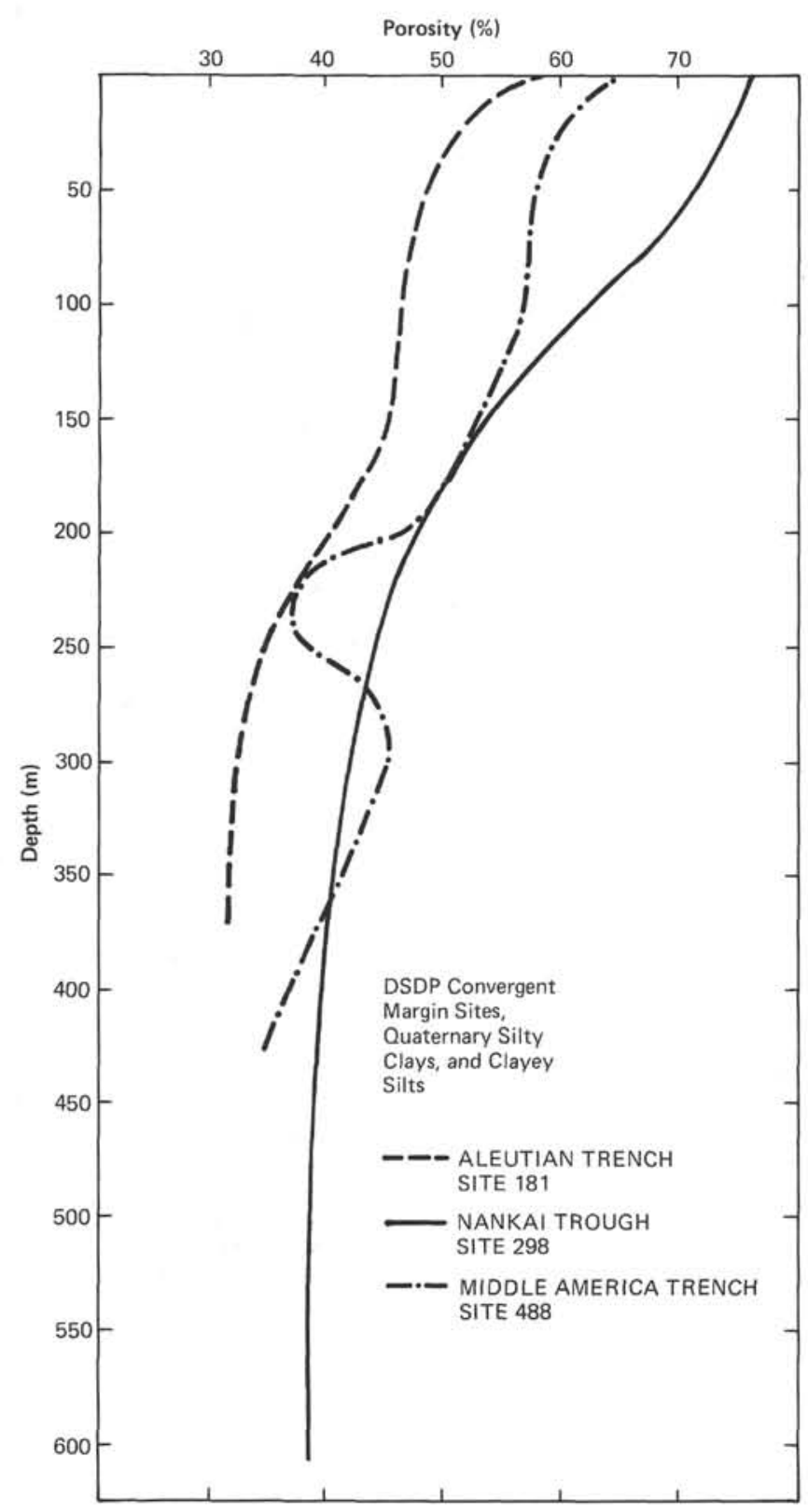

Figure 19. Porosity depth profiles for Quaternary clayey silt and silty clay sediments sampled in the Aleutian Trench, DSDP Site 181, Nankai Trough, DSDP Site 298, and Middle America Trench, DSDP Site 488.
Site 492 sediments above the zone of gas-related disturbance are overconsolidated, whereas Site 491 sediments become underconsolidated with depth. Site 488 sediments, located only $4 \mathrm{~km}$ landward of the trench axis near the toe of the lower inner slope, are underconsolidated.

Comparing $e$-log $P$ curves from other convergent margin drill sites-DSDP Legs 31 (Sample 298-11-3, 297 $\mathrm{m}$, Trabant et al., 1975) and 18 (Sample 181-28-1, 322 m; Lee et al., 1973) - and of surficial Sample 90-2 from the Washington continental slope (Carson, 1977) with Leg 66 results (Samples 488-30-1, $176 \mathrm{~m}$, and 492-12-4, $108 \mathrm{~m}$ ) illustrates the difference in consolidation characteristics (Fig. 20). An example of Japan Trench Site 440 $e$ - $\log P$ curves is not shown because void ratios exceed 1.70 at depths greater than 550 meters. These data show that the break in slope used to compute the maximum presssure $P_{c}$ to which a sediment has consolidated in the past occurs at a much lower pressure for Sample 48830-1 than for any other sample. Overconsolidated sam-

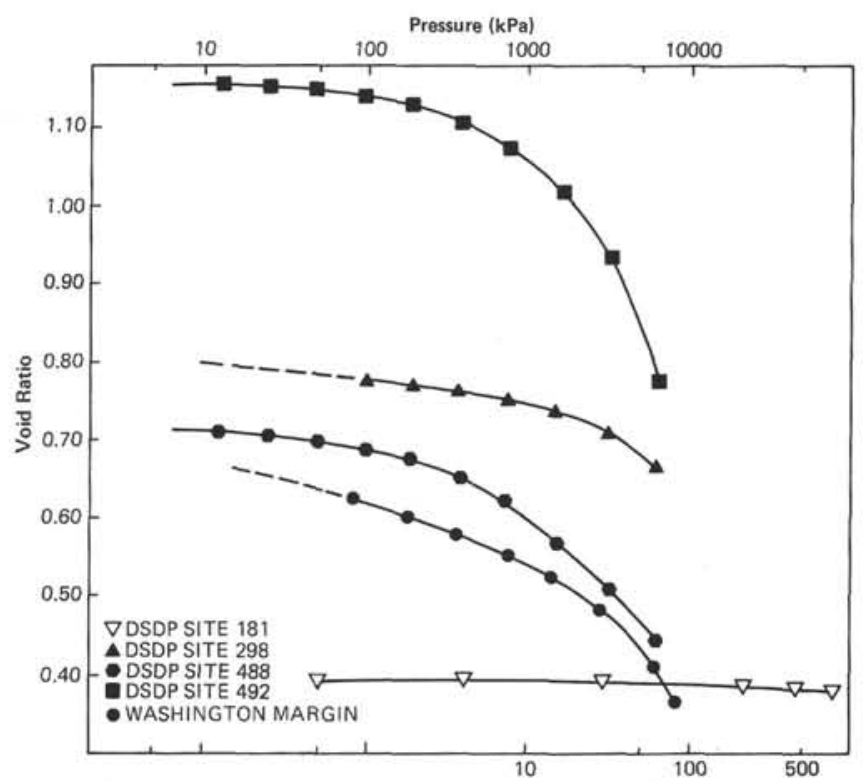

Figure 20. Consolidation test results, $e$-log $P$ curves, of convergent margin sediments from DSDP Sites 181, 298, and 488 and from the Washington continental margin. Sample 90-2, showing the break in slope at low pressure $(\simeq 200 \mathrm{kPa})$ for Site 488 , indicating underconsolidation. Curves from previously drilled convergent margin sites from Lee et al. (1973), Trabant et al. (1975), and Carson (1977). 
ples from the Nankai Trough and particularly the Aleutian Trench show little change in void ratio under the maximum load applied in the laboratory. Although all samples except 90-2 from the Washington continental margin were obtained by standard DSDP rotary drilling and handling techniques, all are similar lithologically, and all were tested using one-dimensional consolidation apparatus, obvious differences in the state of consolidation are still apparent.

Samples 488-30-1 $(265 \mathrm{~m})$ and 488-33-6 $(302.50 \mathrm{~m})$ are located only 48 and 11 meters, respectively, above the first occurrence of thick sands. If these sands represent accreted trench sediments, the proximity of the two consolidation samples to these sands would suggest they are either accreted sediments or represent lower slope sediments which should have been directly affected by the accretion process. In either case the general geotechnical property model indicates these sediments should be overconsolidated and highly dewatered. However, if these sands were originally deposited on the lower trench inner slope and essentially deformed in place, the overlying clayey silt consolidation samples (488-30-1, 33-36 cm) would not represent sediments directly involved in the accretion process but represent deformed lower trench inner slope sediments instead. In this case one can only speculate on the consolidation state of deeper sediments which may represent accreted material.

Data utilized to develop the general geotechnical property model for active convergent margin sediments were obtained from margins having many similar sitespecific parameters (Table 7). Trench sediment accumulation rates exceed $800 \mathrm{~m} / \mathrm{m}$.y. and result from a high clastic input. Convergence rates for these margins are low to moderate and range from approximately $2 \mathrm{~cm} / \mathrm{y}$. to $6 \mathrm{~cm} / \mathrm{y}$. (Atwater, 1970; Moore and Karig, 1976). This combination of high sediment accumulation rates and low convergence rates has resulted in a very thick trench sediment section. Horst and graben structures, normal faults or topographic irregularities on the oceanic plate as it descends into the subduction zone, are poorly developed or absent entirely. Seismic reflection profiles collected from these areas show uplifted anticlinal ridges, becoming progressively more faulted and folded landward along the lower trench inner slope (Hilde et al., 1969; Carson, 1977; Barnard, 1978). Combining these data with previously described geotechnical property results indicates that for "clastic-dominated" margins sediments are deformed by folding and faulting against the toe of the lower trench inner slope in the initial stage of the accretion process. Near-surface deforming sediments begin to dewater over relatively short drainage paths, becoming progressively overconsolidated through time.

Site-specific parameters for the Japan Trench margin (Table 7) include low sediment accumulation rates in the trench, high convergence rates $(8 \mathrm{~cm} / \mathrm{y} .-10 \mathrm{~cm} / \mathrm{y}$.), and a thin trench sediment section. Horst and graben structures are well developed on the oceanic plate, and deformation at the toe of the lower trench slope is not as pervasive as in the clastic-dominated margins. Geotechnical property data reveal high-porosity, low-density underconsolidated sediments which persist at depth. These data indicate that convergence at "pelagic-dominated" margins results in large quantities of high water content sediments descending below underconsolidated lower trench inner slope sediments. The pelagic sediments would be rapidly loaded and may dewater, causing abnormally pressured overlying sediments. Overpressured lower trench inner slope sediments would be deformed in situ.

Site-specific parameters of the Middle America Trench margin suggest it is intermediate between the clasticand pelagic-dominated margins. Clastic sediment accumulation rates in the trench are substantial, but convergence rates of $7 \mathrm{~cm} / \mathrm{y}$. carry large volumes of pelagic sediments into the subduction complex. Deformation occurring along the lower trench slope is evident from geophysical, sedimentological, and geotechnical data. This deformation does not appear as pervasive as in clastic-dominated margins and has not resulted in highly overconsolidated sediments at shallow depths.

Table 7. Summary of general geotechnical property data and site-specific parameters for each of the margins discussed.

\begin{tabular}{|c|c|c|c|c|c|}
\hline Convergent Margin & $\begin{array}{l}\text { Middle America } \\
\text { Trench } \\
\text { DSDP Site } 488\end{array}$ & $\begin{array}{c}\text { Aleutian } \\
\text { Trench } \\
\text { DSDP Site } 181\end{array}$ & $\begin{array}{c}\text { Nankai } \\
\text { Trough } \\
\text { DSDP Site } 298\end{array}$ & $\begin{array}{c}\text { Japan } \\
\text { Trench } \\
\text { DSDP Site } 440\end{array}$ & $\begin{array}{l}\text { Washington } \\
\text { Continental } \\
\text { Margin }\end{array}$ \\
\hline $\begin{array}{l}\text { Oldest Age of } \\
\text { Sediments Tested }\end{array}$ & Quaternary & Quaternary & Quaternary & Pliocene-late Miocene & Quaternary \\
\hline Consolidation Characteristics & Underconsolidated & $\begin{array}{c}\text { Highly } \\
\text { Overconsolidated }\end{array}$ & $\begin{array}{c}\text { Highly } \\
\text { Overconsolidated }\end{array}$ & Underconsolidated & $\begin{array}{c}\text { Highly } \\
\text { Overconsolidated }\end{array}$ \\
\hline $\begin{array}{l}\text { Minimum Porosity }(\%) \\
\text { Trench and Lower Slope } \\
\text { Sedimentation Rate }(\mathrm{m} / \mathrm{m} . \mathrm{y} .)\end{array}$ & $\simeq \begin{aligned} 33 \\
\simeq\end{aligned}$ & $\begin{array}{c}32 \\
\simeq 1700^{\mathrm{a}}\end{array}$ & $\begin{aligned} & 35 \\
\simeq & 700^{\mathrm{b}}\end{aligned}$ & $\begin{aligned} & 55 \\
\simeq & 200^{\mathrm{b}}\end{aligned}$ & $\begin{aligned} & 36 \\
&=2000^{\mathrm{a}}\end{aligned}$ \\
\hline $\begin{array}{l}\text { Trench Sediment } \\
\text { Thickness (m) }\end{array}$ & $\simeq 600$ & $>1100$ & $\simeq 700$ & $\simeq 500$ & $\approx 1300$ \\
\hline Convergence Rate $(\mathrm{cm} / \mathrm{y}$.) & $\simeq 7$ & $\simeq 6$ & $\simeq 2$ & $8-10$ & $<2$ \\
\hline
\end{tabular}

Note: Data obtained from Molnar and Sykes, 1969; Atwater, 1970; Kulm et al., 1973; Lee et al., 1973; Trabant et al., 1975; Moore and Karig, 1976; Carson, 1977; Minster and Jordan, 1978; and von Huene, 1980.

a Trench.

b Lower slope. 
Results of geotechnical investigations from both the Middle America Trench and the Japan Trench indicate that the convergence process does not always result in highly deformed low-porosity, overconsolidated sediments. Deformation in lower trench slope sediments may occur from the development of excess porewater pressures and oversteepened slopes related to the convergence process but not necessarily a direct result of accretion. Site-specific parameters should be carefully considered when analyzing the effects of the convergence process on sediment geotechnical properties.

\section{ACKNOWLEDGMENTS}

We greatly appreciate the assistance of DSDP and Global Marine personnel and are grateful to the shipboard scientific party for making Leg 66 an enjoyable venture. Special thanks and four "good core" awards are extended to W. Brennan, C. Deen, D. Marsee, and W. Meyers. T. C. Chamberlain and Hondo Crouch, imagineer, provided insight.

R. H. Bennett and W. E. Hottman reviewed the manuscript.

\section{REFERENCES}

Atwater, T., 1970. Implications of plate tectonics for the Cenozoic tectonic evolution of Western North America. Geol. Soc. Am. Bull., 81:3513-3536.

Barnard, W. D., 1978. The Washington continental slope: Quaternary tectonics and sedimentation. Mar. Geol., 27:79-114.

Bennett, R. H., Bryant, W. R., and Keller, G. H., 1977. Clay fabric and geotechnical properties of selected submarine sediment cores from the Mississippi Delta. NOAA Prof. Pap. 9, U.S. Department of Commerce.

Bennett, R. H., and Keller, G. H., 1973. Physical properties evaluation. In van Andel, $\mathrm{Tj}$. H., Heath, G. R., et al., Init. Repts. DSDP, 16: Washington (U.S. Govt. Printing Office), 513-520.

Bouma, A. H., and Moore, J. C., 1975. Physical properties of deepsea sediments from the Philippine Sea and Sea of Japan. In Karig, D. E., Ingle, J. C., Jr., et al., Init. Repts. DSDP, 31: Washington (U.S. Govt. Printing Office), 535-568.

Bowles, J. E., 1970. Engineering Properties of Soils and Their Measurement: New York (McGraw-Hill, Inc.).

Boyce, R. E., 1975. Definitions and laboratory techniques of compressional sound velocity parameters and wet water content, wetbulk density, and porosity parameters by gravimetric and gamma ray attenuation techniques. In Schlanger, S. O., Jackson, E. D., et al., Init. Repts. DSDP, 33: Washington (U.S. Govt. Printing Office), 931-951.

1977. Deep Sea Drilling Project procedures for shear strength measurement of clayey sediment using modified Wykeham Farrance laboratory vane apparatus. In Barker, P. F., Dalziel, I. W. D., et al., Init. Repts. DSDP, 36: Washington (U.S. Govt. Printing Office), 1059-1068.

Bredehoft, J. D., and Hanshaw, B. B., 1968. On the maintenance of anomalous fluid pressures: Thick sedimentary sequences. Geol. Soc. Am. Bull., 81:1097-1106.

Carson, B., 1977. Tectonically induced deformation of deep-sea sediments off Washington and northern Oregon. Mar. Geol., 24: 289-307.

Carson, B., and Bruns, T. R., 1980. Physical properties of sediments from the Japan Trench margin and outer trench slope: Results from DSDP Legs 56 and 57. In Scientific Party, Init. Repts. $D S D P, 56,57$, Pt. 2: Washington (U.S. Govt. Printing Office), $1187-1200$.

Carson, B., Yuan, J., Meyers, P. B., et al., 1974. Initial deep-sea sediment deformation at the base of the Washington continental slope: A response to subduction. Geology, 2:561-564.

Casagrande, A., 1936. The determination of the preconsolidation load and its practical significance. Proc. Int. Conf. Soil Mech. Found. Eng. 3rd, pp. 60-64.
Cernock, P. J., 1970. Sound velocities in Gulf of Mexico sediments as related to physical properties and simulated overburden pressures [Ph.D. dissert.]. Texas A\&M University, College Station.

Demars, K. R., and Nacci, V. A., 1977. Significance of Deep Sea Drilling Project sediment physical property data. Mar. Geotechnol., 3:151-170.

Hamilton, E. L., 1964. Consolidation characteristics and related properties of sediments from experimental Mohole (Guadalupe Site). $J$. Geophys. Res., 69:4257-4269. 1976. Variations of density and porosity in deep-sea sediments, J. Sediment. Petrol., 46:280-300.

Hilde, T. W. C., Wageman, J. M., and Hammond, W. T., 1969. The structure of Tora Terrace and Nankai Trough off southwestern Japan. Deep-Sea Res., 16:66-75.

Hottman, C. E., and Smith, J. H., 1978. Relationship among earth stresses, pore pressures and drilling problems offshore Gulf of Alaska, Soc. Petr. Eng., 53rd Annual Tech. Conf., SPE7501, Houston.

Kulm, L. D., von Huene, R., et al., 1973. Init. Repts. DSDP, 18: Washington (U.S. Govt. Printing Office).

Lee, H. J., Olson, H. W., and von Huene, R., 1973. Physical properties of deformed sediments from Site 181. In Kulm, L. D., von Huene, R., et al., Init. Repts. DSDP, 18: Washington (U.S. Govt. Printing Office), 701-719.

Lowe, J., Zaccheo, P. F., and Feldman, H. S., 1964. Consolidation testing with back pressure. Jour. Soil Mechanics and Foundation Division, American Soc. Civil Engineers, 90:69-86.

Minster, J. B., and Jordan, T. H., 1978. Present day plate motions. J. Geophys. Res., 80:5331-5354.

Mitchell, J. K., 1976. Fundamentals of Soil Behavior: New York (John Wiley \& Sons).

Molnar, P., and Sykes, L. R., 1969. Tectonics of the Caribbean and Middle America regions from focal mechanisms and seismicity. Geol. Soc. Am. Bull., 80:1639-1684.

Moore, J. C., and Karig, D. E., 1976. Sedimentology, structural geology, and tectonics of the Shikaku subduction zone, southwestern Japan. Geol. Soc. Am. Bull., 87:1259-1268.

Nafe, J. E., and Drake, C. L., 1957. Physical properties of marine sediments. In Hill, M. N. (Ed.), The Sea (Vol. 3): New York (Interscience), 794-828.

Schmertmann, J. M., 1955. The undisturbed consolidation of clay. Trans. Am. Soc. Civ. Eng., 120:1201-1233.

Seely, D. R., 1977. The significance of landward vergence and oblique structural trends on trench inner slopes. Island arcs, Deep Sea Trenches and Back-arc Basins: American Geophysical Union Maurice Ewing Series 1, pp. 187-198.

Shephard, L. E., and Bryant, W. R., 1980. Consolidation characteristics of Japan Trench sediments. In Scientific Party, Init. Repts. DSDP, 56, 57, Pt. 2: Washington (U.S. Govt. Printing Office), 1201-1206.

Silva, A. J., 1975. Marine geomechanics-an overview and projections. Deep-sea Sediments-Physical and Mechanical Properties: New York (Plenum Press), pp. 45-76.

Silver, E. A., 1972. Pleistocene tectonic accretion of the continental slope off Washington. Mar. Geol., 13:239-250.

Skempton, A. W., 1970. The consolidation of clays by gravitational compaction. Q. J. Geol. Soc. London, 125:373-411.

Trabant, P. K., Bryant, W. R., and Bouma, A. H., 1975. Consolidation characteristics of sediments from Leg 31 of the Deep Sea Drilling Project. In Karig, D. E., Ingle, J. C., Jr., et al., Init. Repts. DSDP, 31: Washington (U.S. Govt. Printing Office), 569-572.

von Huene, R., Aubouin, J., Azema, J., et al., 1980. Leg 67: The Deep Sea Drilling Project Mid-America Trench off Guatemala. Geol. Soc. Am. Bull., 91:421-432.

Woodbury, H. O., Spotts, J. H., and Ahres, W. H., 1978. Gulf of Mexico continental slope sediments and sedimentation. In Bouma, A. H., Moore, G. T., and Coleman, J. M. (Eds.), Framework, Facies and Oil Trapping Characteristics of the Upper Continental Margin. AAPG Studies in Geology, Tulsa: (American Association of Petroleum Geologists), pp. 117-138. 
APPENDIX

Leg 66 Geotechnical Property Measurements

\begin{tabular}{|c|c|c|c|c|}
\hline & & & & $\begin{array}{c}\text { Conti } \\
\text { GR }\end{array}$ \\
\hline & & & $\begin{array}{l}\text { Sub-bottom } \\
\text { Depth }\end{array}$ & $\begin{array}{c}\text { Bulk } \\
\text { Density }\end{array}$ \\
\hline Core & Section & $(\mathrm{cm})$ & & \\
\hline Hole & & & & \\
\hline 2 & 1 & $109-112$ & 2.1 & \\
\hline 2 & 2 & $109-112$ & 3.6 & \\
\hline 2 & 3 & $109-112$ & 4.7 & \\
\hline 2 & 4 & $109-112$ & 5.8 & 1.385 \\
\hline 3 & 1 & 86-88 & 11.38 & \\
\hline 3 & 1 & $89-92$ & 11.40 & \\
\hline 3 & 2 & $29-31$ & 12.45 & 1.408 \\
\hline 3 & 2 & 44-47 & 12.60 & \\
\hline 3 & 3 & $59-62$ & 14.10 & \\
\hline 3 & 4 & $59-62$ & 15.60 & 1.418 \\
\hline 3 & 5 & $29-31$ & 16.80 & 1.408 \\
\hline 3 & 5 & $89-92$ & 17.40 & \\
\hline 5 & 1 & $129-131$ & 30.80 & \\
\hline 5 & 2 & $18-20$ & 31.20 & \\
\hline 5 & 2 & $109-112$ & 32.10 & 1.400 \\
\hline 5 & 3 & $130-132$ & 33.81 & 1.409 \\
\hline 6 & $i$ & $109-112$ & 40.10 & \\
\hline 6 & 2 & $19-21$ & 40.70 & 1.440 \\
\hline 6 & 3 & $29-31$ & 42.30 & 1.440 \\
\hline 6 & 3 & $109-112$ & 43,10 & 1.414 \\
\hline 7 & 1 & $119-122$ & 49.70 & \\
\hline 8 & 1 & $84-87$ & 58.85 & \\
\hline 8 & 3 & $19-22$ & 61.20 & \\
\hline 8 & 3 & $109-111$ & 62.10 & \\
\hline 8 & 4 & $19-21$ & 62.70 & 1.410 \\
\hline 8 & 4 & $118-120$ & 63.70 & \\
\hline 8 & 5 & $9-11$ & 64.10 & \\
\hline 8 & 5 & $109-112$ & 65.10 & \\
\hline 8 & 6 & $59-61$ & 66.10 & 1.414 \\
\hline 9 & 1 & $99-102$ & 68.50 & \\
\hline 9 & 3 & $19-22$ & 70.70 & \\
\hline 9 & 3 & $119-121$ & 71.70 & \\
\hline 9 & 4 & $39-41$ & 72.40 & 1.391 \\
\hline 9 & 5 & $50-52$ & & \\
\hline 9 & 6 & $58-61$ & 75.60 & 1.408 \\
\hline 10 & 1 & $99-102$ & 78.00 & \\
\hline 10 & 2 & $29-32$ & 78.80 & 1.418 \\
\hline 10 & 4 & $131-133$ & 82.82 & 1.410 \\
\hline 10 & 5 & $19-22$ & 83.20 & \\
\hline 10 & 5 & $115-117$ & 84.15 & \\
\hline 10 & 6 & $84-86$ & 85.35 & 1.470 \\
\hline 11 & 1 & $117-120$ & 87.68 & \\
\hline 11 & 2 & $120-122$ & 89.20 & \\
\hline 11 & 3 & $95-98$ & 90.46 & \\
\hline 11 & 4 & $79-81$ & 91.80 & 1.392 \\
\hline 12 & 3 & $8-11$ & 99.10 & \\
\hline 12 & 3 & $119-121$ & 100.20 & 1.232 \\
\hline 12 & 4 & $78-81$ & 101.30 & \\
\hline 12 & 5 & $47-49$ & 102.48 & \\
\hline 13 & 3 & 98-101 & 109.5 & \\
\hline 13 & 4 & $18-21$ & 110.2 & 1.389 \\
\hline 13 & 4 & $123-126$ & 111.25 & \\
\hline 13 & 4 & $79-81$ & 110.8 & \\
\hline 13 & 5 & $14-16$ & 111.65 & \\
\hline 14 & 1 & $108-111$ & 116.10 & 1.377 \\
\hline 14 & 2 & $89-92$ & 117.38 & \\
\hline 14 & 3 & $50-52$ & 118.50 & \\
\hline 14 & 3 & $113-116$ & 119.15 & 1.472 \\
\hline 15 & 2 & $128-131$ & 127.80 & 1.317 \\
\hline 15 & 3 & $113-116$ & 128.55 & \\
\hline 15 & 4 & $109-111$ & 130.10 & 1.302 \\
\hline 15 & 5 & $88-91$ & 131.40 & \\
\hline 15 & 6 & $108-110$ & 133.09 & 1.249 \\
\hline 16 & 1 & $34-36$ & 134.34 & \\
\hline 16 & 2 & $84-86$ & 136.35 & 1.260 \\
\hline 18 & 2 & $99-101$ & 155.50 & 1.404 \\
\hline 18 & 4 & $128-131$ & 158.80 & 1.431 \\
\hline 18 & 5 & $100-103$ & 160.00 & \\
\hline Hole & & & & \\
\hline 2 & 1 & $100-103$ & 2.0 & \\
\hline 2 & 2 & $20-23$ & 2.70 & \\
\hline 2 & 2 & $90-93$ & 3.40 & \\
\hline 2 & 3 & $50-52$ & 4.50 & \\
\hline 2 & 3 & $110-113$ & 5.10 & \\
\hline 2 & 4 & $99-102$ & 6.50 & \\
\hline & 1 & $129-132$ & 11.80 & \\
\hline 3 & 1 & $140-143$ & 11.9 & \\
\hline 3 & 1 & $49-52$ & 11.0 & \\
\hline 3 & 2 & $128-140$ & 13.30 & 1.41 \\
\hline 3 & 2 & $9-12$ & 12.10 & \\
\hline 3 & 2 & $50-52$ & 12.50 & \\
\hline 3 & 2 & $119-122$ & 13.20 & \\
\hline 4 & 1 & $99-103$ & 21.0 & \\
\hline 4 & 2 & $137-140$ & 22.9 & \\
\hline 4 & 3 & $27-30$ & 24.25 & \\
\hline 4 & 3 & $126-129$ & 23.30 & \\
\hline 4 & 4 & 63-66 & 25.13 & \\
\hline 4 & 5 & $99-102$ & 27.00 & \\
\hline 4 & 5 & $138-150$ & & \\
\hline 4 & 6 & $54-57$ & 28.05 & \\
\hline
\end{tabular}




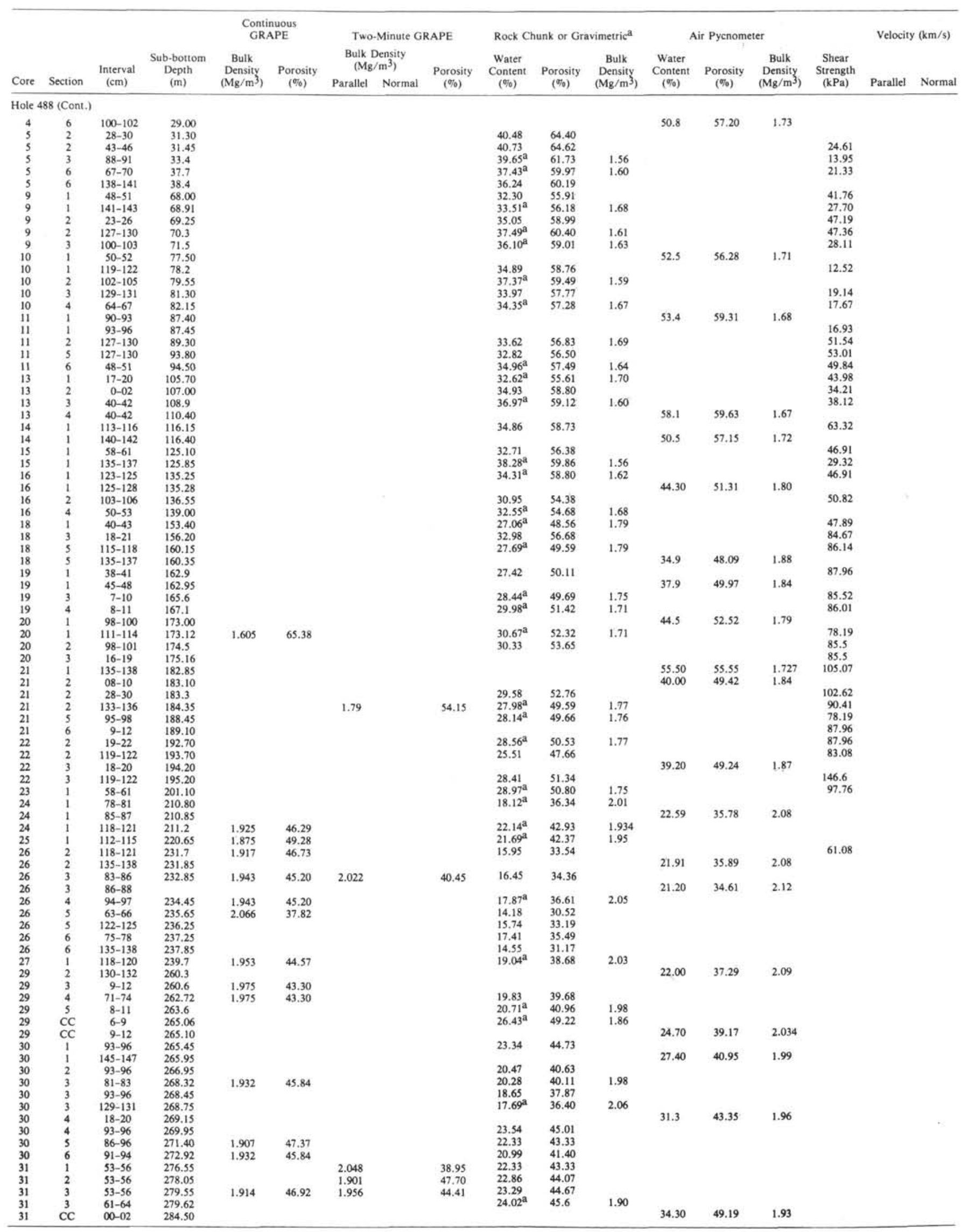




\begin{tabular}{|c|c|c|c|c|c|}
\hline & & & & $\begin{array}{c}\text { Conti } \\
\text { GR }\end{array}$ & $\begin{array}{l}\text { uous } \\
\mathrm{PE}\end{array}$ \\
\hline & & & $\begin{array}{l}\text { Sub-bottom } \\
\text { Depth }\end{array}$ & $\begin{array}{c}\text { Bulk } \\
\text { Density }\end{array}$ & Porosity \\
\hline Core & Section & $(\mathrm{cm})$ & & & $\left(\%_{0}\right)$ \\
\hline Hole 4 & 88 (Cont. & & & & \\
\hline 32 & 1 & $87-90$ & 285.90 & & \\
\hline 32 & 2 & $80-83$ & 287.32 & & \\
\hline 32 & 3 & $75-78$ & 288.76 & & \\
\hline 32 & 4 & $75-78$ & 290.26 & & \\
\hline 32 & 5 & $8-11$ & 291.10 & & \\
\hline 32 & 4 & $43-45$ & 289.96 & & \\
\hline 33 & 1 & $52-55$ & 294.54 & & \\
\hline 33 & 1 & $103-106$ & 296.55 & & \\
\hline 33 & 2 & $132-135$ & 296.85 & & \\
\hline 33 & 3 & $61-64$ & 297.62 & e & \\
\hline 33 & 4 & $118-121$ & 299.7 & & \\
\hline 33 & 5 & $65-68$ & 300.65 & & \\
\hline 33 & 6 & $50-55$ & 302.00 & & \\
\hline 33 & 6 & 95-98 & 302.45 & & \\
\hline 34 & 1 & 95-98 & 303.96 & & \\
\hline 34 & 2 & $74-77$ & 305.25 & & \\
\hline 34 & 3 & $78-81$ & 306.80 & & \\
\hline 34 & 4 & $128-131$ & 308.80 & & \\
\hline 34 & 4 & $128-131$ & 308.80 & & \\
\hline 39 & 1 & $78-82$ & 353.3 & & \\
\hline 40 & 1 & $78-82$ & 362.8 & & \\
\hline 40 & 1 & $137-139$ & 363.39 & & \\
\hline 40 & 1 & $146-148$ & 363.47 & & \\
\hline 42 & 1 & $141-144$ & 382.43 & & \\
\hline 42 & 2 & $13-16$ & 382.65 & & \\
\hline 42 & 2 & $27-30$ & 382.80 & & \\
\hline 42 & 3 & $26-29$ & 384.26 & 1.92 & 46.41 \\
\hline 42 & 3 & $30-32$ & 384.28 & & \\
\hline 43 & 1 & $140-143$ & 391.9 & & \\
\hline 44 & 1 & $23-25$ & 400.23 & & \\
\hline 46 & ${ }^{1}$ & $105-107$ & 420.05 & & \\
\hline Hole & $489 \mathrm{~A}$ & & & & \\
\hline 1 & 1 & $140-143$ & 1.40 & & \\
\hline 1 & 2 & $8-10$ & 1.60 & 1.84 & 51.59 \\
\hline $\begin{array}{l}1 \\
1\end{array}$ & $\begin{array}{l}2 \\
3\end{array}$ & $\begin{array}{c}124-128 \\
13-16\end{array}$ & $\begin{array}{l}2.75 \\
3.15\end{array}$ & & \\
\hline i & 3 & $78-81$ & 3.80 & & \\
\hline 1 & 4 & $80-83$ & 5.30 & 1.93 & 45.83 \\
\hline 2 & 1 & $123-128$ & 7.25 & & \\
\hline 2 & 2 & $130-133$ & 8.80 & & \\
\hline 2 & 3 & $76-79$ & 9.75 & & \\
\hline 2 & 4 & $13-15$ & 10.65 & & \\
\hline 2 & 4 & $59-62$ & 11.10 & 1.85 & 50.57 \\
\hline 2 & 4 & $106-109$ & 11.55 & & \\
\hline 2 & 5 & $14-17$ & 12.15 & & \\
\hline 2 & 5 & $117-120$ & 13.15 & & \\
\hline 2 & 6 & $25-28$ & 13.75 & 1.83 & 52.11 \\
\hline 2 & 6 & $114-118$ & 14.68 & & \\
\hline 3 & 5 & $143-145$ & 22.95 & 1.84 & 51.25 \\
\hline 4 & 1 & $147-150$ & 26.50 & & \\
\hline 4 & 2 & $143-147$ & 27.95 & & \\
\hline 4 & 1 & $27-30$ & 55.30 & & \\
\hline 4 & 1 & 103-107 & 56.05 & & \\
\hline 4 & 2 & 93-96 & 57.45 & 2.04 & 39.24 \\
\hline 4 & 3 & $63-67$ & 58.65 & & \\
\hline 4 & 4 & $135-138$ & 59.35 & & \\
\hline 4 & 4 & $16-20$ & 59.70 & 1.98 & 43.22 \\
\hline 4 & 5 & $98-100$ & 62.00 & & \\
\hline 4 & $\mathrm{CC}$ & $7-10$ & 64.60 & & \\
\hline 5 & 1 & $18-22$ & 65.20 & & \\
\hline 5 & 2 & $19-22$ & 66.70 & 1.98 & 43.20 \\
\hline 5 & 4 & $101-104$ & 70.53 & 1.90 & 47.58 \\
\hline 6 & 1 & $147-150$ & 76.00 & & \\
\hline 6 & 2 & $58-61$ & 76.60 & 1.78 & 54.90 \\
\hline 6 & 3 & $40-43$ & 77.90 & 1.89 & 48.64 \\
\hline 7 & 1 & $60-65$ & 84.65 & & \\
\hline 7 & 2 & $71-75$ & 86.25 & 1.92 & 46.77 \\
\hline 7 & 3 & $98-102$ & 88.00 & & \\
\hline 7 & 5 & $18-20$ & 90.20 & & \\
\hline 8 & 1 & $49-53$ & 94.00 & & \\
\hline 8 & 2 & $49-51$ & 95.50 & & \\
\hline 8 & 3 & $12-15$ & 96.65 & 1.83 & 51.88 \\
\hline 9 & 2 & $147-150$ & 106.00 & & \\
\hline 9 & 3 & $3-5$ & 106.05 & & \\
\hline 9 & 3 & $5-7$ & 106.05 & & \\
\hline 10 & 1 & 3-7 & 112.55 & & \\
\hline 10 & $\mathrm{CC}$ & $3-7$ & & & \\
\hline 11 & 1 & $146-150$ & 123.50 & & \\
\hline 11 & 2 & $89-93$ & 124.40 & & \\
\hline 11 & 3 & $110-113$ & 126.10 & 1.83 & 52.16 \\
\hline 12 & 1 & $119-121$ & 132.70 & & \\
\hline 12 & 2 & $133-136$ & 134.35 & & \\
\hline 13 & 2 & $10-12$ & 142.60 & & \\
\hline 13 & 2 & $10-12$ & 142.60 & & \\
\hline 13 & 3 & $88-90$ & 143.40 & 1.86 & 49.98 \\
\hline 15 & 1 & $13-16$ & 160.15 & & \\
\hline 16 & 2 & $52-54$ & 166.53 & & \\
\hline 16 & 3 & $130-133$ & 168.62 & 1.84 & 51.51 \\
\hline 16 & 4 & $23-25$ & 169.25 & & \\
\hline 16 & 4 & $23-27$ & 169.25 & & \\
\hline
\end{tabular}




\begin{tabular}{|c|c|c|c|c|c|c|c|c|c|c|c|c|c|c|c|}
\hline & & & & $\begin{array}{c}\text { Contin } \\
\text { GRA }\end{array}$ & $\begin{array}{l}\text { unous } \\
\mathrm{PE}\end{array}$ & Two- & Minute GR & RAPE & Rock $\mathrm{Ch}$ & unk or Gra & vimetric $^{a}$ & & ir Pycnomet & & \\
\hline & & $\underset{(\mathrm{cm})}{\text { Interval }}$ & $\begin{array}{l}\text { Sub-bottom } \\
\text { Depth } \\
(\mathrm{m})\end{array}$ & $\begin{array}{c}\text { Bulk } \\
\text { Density } \\
\left({\left.\mathrm{Mg} / \mathrm{m}^{3}\right)}^{2}\right.\end{array}$ & Porosity & $\begin{array}{l}\text { Bulk } \mathrm{D} \\
\left(\mathrm{M}_{\mathrm{B}}\right.\end{array}$ & $\begin{array}{l}\text { ensity } \\
\mathrm{m}^{3} \text { ) }\end{array}$ & Porosity & $\begin{array}{c}\text { Water } \\
\text { Content }\end{array}$ & Porosity & $\begin{array}{c}\text { Bulk } \\
\text { Density }\end{array}$ & $\begin{array}{c}\text { Water } \\
\text { Content }\end{array}$ & Porosity & $\begin{array}{c}\text { Bulk } \\
\text { Density }\end{array}$ & $\begin{array}{l}\text { Shear } \\
\text { Strength }\end{array}$ \\
\hline Core & Section & $(\mathrm{cm})$ & & & $(\%)$ & Parallel & Normal & $(\%)$ & & & & & & & \\
\hline Hole 4 & 89A (Cor & & & & & & & & & & & & & & \\
\hline $\begin{array}{l}17 \\
17\end{array}$ & 1 & $98-101$ & 170.5 & & & 2.05 & & 38.63 & 22.78 & 44.46 & & & & & \\
\hline 17 & 2 & $\begin{array}{l}43-43 \\
45-47\end{array}$ & $\begin{array}{l}771.45 \\
171.45\end{array}$ & 1.81 & 53.02 & 1.99 & & 42.65 & $23.70^{\mathrm{a}}$ & 45,24 & 191 & 25.48 & 46.85 & 1.92 & \\
\hline 18 & i & $98-101$ & 180.00 & & & 1.99 & & & 24.07 & 45.24 & 1.91 & & & & \\
\hline 18 & 2 & $\begin{array}{r}99-102 \\
103-106\end{array}$ & $\begin{array}{l}181.50 \\
183.05\end{array}$ & 1.84 & 51.25 & & & & $22.09^{\mathrm{a}}$ & 44.22 & 2.00 & & & & \\
\hline $\begin{array}{l}18 \\
19\end{array}$ & $\begin{array}{l}3 \\
1\end{array}$ & $\begin{array}{c}103-106 \\
8-10\end{array}$ & $\begin{array}{l}\begin{array}{l}83.05 \\
183.10\end{array}\end{array}$ & 1.81 & 53.26 & & & & $18.98^{\mathrm{a}}$ & 36.97 & 2.05 & & & & \\
\hline 19 & 3 & $91-93$ & $\begin{array}{l}186.92 \\
182\end{array}$ & & & 2.18 & & 31.10 & $\begin{array}{l}21.02 \\
17.55\end{array}$ & $\begin{array}{l}41.94 \\
36.62\end{array}$ & & & & & \\
\hline 19 & $\mathrm{Cc}$ & $7-10$ & & & & 2.14 & & 33.38 & & 36.62 & & & & & \\
\hline $\begin{array}{l}19 \\
20\end{array}$ & ${ }_{C C}^{1}$ & $\begin{array}{r}90-92 \\
8-11\end{array}$ & 183.90 & & & 2.10 & & 35.95 & $17.28^{\mathrm{a}}$ & 35.89 & 2.08 & & & & \\
\hline $\begin{array}{l}20 \\
21\end{array}$ & $\begin{array}{c}\mathrm{CC} \\
3\end{array}$ & $\begin{array}{c}8-11 \\
118-122\end{array}$ & 202.20 & & & 2.09 & & 36.54 & $19.78^{\mathrm{a}}$ & 39.24 & 1.98 & & & & \\
\hline $\begin{array}{l}21 \\
21\end{array}$ & $\begin{array}{l}3 \\
4\end{array}$ & $28-31$ & $\begin{array}{l}202.20 \\
202.80\end{array}$ & & & $\begin{array}{l}2.17 \\
2.15\end{array}$ & & 31.34 & 20.93 & 41.84 & & & & & \\
\hline 21 & 5 & $49-52$ & 204.50 & 1.82 & 49.65 & 2.16 & & $\begin{array}{l}32.83 \\
32.10\end{array}$ & $\begin{array}{l}20.12 \\
17.59^{\mathrm{a}}\end{array}$ & $\begin{array}{l}40.60 \\
36.28\end{array}$ & 2.06 & & & & \\
\hline 21 & 6 & $24-27$ & 205.75 & & & 2.16 & & 32.10 & 19.75 & 40.05 & 2.00 & & & & \\
\hline 22 & 2 & & $\begin{array}{l}210.03 \\
211.05\end{array}$ & & & & & & $16.91^{\mathrm{a}}$ & 35.22 & 2.08 & & & & \\
\hline 22 & 3 & $\begin{array}{c}103-107 \\
58-61\end{array}$ & $\begin{array}{l}211.05 \\
212.60\end{array}$ & & & & & & 17.14 & $\begin{array}{l}35.96 \\
34.30\end{array}$ & & & & & \\
\hline 22 & 4 & $\begin{array}{l}58-61 \\
93-96\end{array}$ & $\begin{array}{l}\begin{array}{l}212.60 \\
214.46\end{array} \\
210\end{array}$ & & & & & & $\begin{array}{l}16.13 \\
17.36\end{array}$ & $\begin{array}{l}34.30 \\
336.31\end{array}$ & & & & & \\
\hline 22 & 5 & $\begin{array}{c}93-96 \\
128-132\end{array}$ & $\begin{array}{l}\begin{array}{l}214.46 \\
219.80\end{array} \\
210.8\end{array}$ & 1.85 & 50.82 & & & & $\begin{array}{r}17.36 \\
2.04\end{array}$ & & & & & & \\
\hline 23 & $\begin{array}{l}2 \\
4\end{array}$ & $\begin{array}{c}128-132 \\
47-51\end{array}$ & 222.00 & & & & & & 15.06 & 32.49 & & & & & \\
\hline $\begin{array}{l}23 \\
24\end{array}$ & $\begin{array}{l}4 \\
2\end{array}$ & $102-106$ & 229.05 & & & 2.19 & & 30.14 & 16.77 & 35.35 & & & & & \\
\hline 24 & 3 & $39-43$ & 229.90 & 1.85 & 50.82 & & & & 16.77 & 35.35 & & & & 218 & \\
\hline 24 & 4 & 13-15 & $\begin{array}{l}231.15 \\
231.30\end{array}$ & & & & & & $15.23^{\mathrm{a}}$ & 32.42 & 2.13 & 15.12 & 31.32 & 2.18 & \\
\hline $\begin{array}{l}24 \\
24\end{array}$ & $\begin{array}{l}4 \\
6\end{array}$ & $\begin{array}{l}28-32 \\
74-78\end{array}$ & $\begin{array}{l}\begin{array}{l}231.30 \\
234.75\end{array} \\
230\end{array}$ & & & & & & $13.23^{\circ}$ & 32.42 & 2.13 & & & & \\
\hline 25 & i & $37-42$ & 236.40 & 1.85 & 50.53 & & & & 15.74 & $\begin{array}{l}35.30 \\
36.68\end{array}$ & & & & & \\
\hline 25 & 4 & $46-50$ & 241.0 & & & & & & $\begin{array}{l}17.59 \\
14.98^{\mathrm{a}}\end{array}$ & $\begin{array}{l}36.68 \\
32.02\end{array}$ & 2.14 & & & & \\
\hline 25 & 4 & $134-138$ & 241.75 & & & & & & $\begin{array}{l}14.98^{\mathrm{a}} \\
16.15\end{array}$ & $\begin{array}{l}32.02 \\
34.33\end{array}$ & 2.14 & & & & \\
\hline 25 & 6 & $23-27$ & 243.75 & & & & & & $\begin{array}{l}16.15 \\
14.90^{\mathrm{a}}\end{array}$ & $\begin{array}{l}34.33 \\
32.24\end{array}$ & 2.16 & & & & \\
\hline 26 & 2 & $65-70$ & 247.70 & 2.09 & 36.22 & & & & $\begin{array}{l}14.90^{\mathrm{a}} \\
11.59^{\mathrm{a}}\end{array}$ & $\begin{array}{l}32.24 \\
26.05\end{array}$ & 2.25 & & & & \\
\hline 26 & 4 & $87-91$ & 250.90 & 2.15 & 32.98 & & & & $\begin{array}{l}11.59^{\mathrm{a}} \\
17.57\end{array}$ & 36.65 & & & & & \\
\hline 27 & 2 & $26-31$ & 256.80 & 1.86 & 50.02 & & & & & $\begin{array}{l}36.63 \\
36.70\end{array}$ & & & & & \\
\hline $\begin{array}{l}27 \\
28\end{array}$ & $\begin{array}{l}3 \\
3\end{array}$ & $\begin{array}{l}55-60 \\
53-57\end{array}$ & $\begin{array}{l}258.60 \\
267.55\end{array}$ & 2.08 & & & & & 13.18 & 29.18 & & & & & \\
\hline 28 & 4 & $0-5$ & 268.55 & & & & & & $14.23^{\mathrm{a}}$ & 30.50 & 2.14 & & & & \\
\hline 29 & 2 & $0-3$ & 274.53 & & & & & & & & & & & & \\
\hline 29 & 3 & $0-3$ & 276.03 & & & & & & & & & & & & \\
\hline $\begin{array}{l}29 \\
30\end{array}$ & 5 & $\begin{array}{l}2-5 \\
2-5\end{array}$ & $\begin{array}{r}279.05 \\
288.05\end{array}$ & 1.90 & 47.84 & & & & $14.08^{\mathrm{a}}$ & 30.46 & 2.16 & & & & \\
\hline $\begin{array}{l}30 \\
30\end{array}$ & $\begin{array}{l}5 \\
5\end{array}$ & $106-110$ & $\begin{array}{l}288.05 \\
289.10\end{array}$ & & & & & & & 30.40 & 2.10 & & & & \\
\hline 30 & 5 & $63-66$ & 288.65 & & & & & & 13.52 & 29.79 & & & & & \\
\hline 31 & 2 & $91-94$ & 293.43 & & & & & & 13.98 & 30.61 & & & & & \\
\hline Hole & & & & & & & & & & & & & & & \\
\hline 1 & 1 & $127-131$ & 1.27 & & & & & & 43.3 & 66.84 & & & & & 20.21 \\
\hline 1 & 2 & $57-60$ & 2.10 & & & & & & $44.6^{\mathrm{a}}$ & 68.40 & 1.53 & & & & 1170 \\
\hline 1 & 2 & $142-147$ & 2.95 & & & & & & 34.2 & 57.84 & & & & & 11.70 \\
\hline 1 & 3 & $\begin{array}{c}45-48 \\
130-134\end{array}$ & $\begin{array}{l}3.45 \\
4.30\end{array}$ & & & & & & 47,6 & 70.57 & & & & & 28.73 \\
\hline 1 & $\begin{array}{l}3 \\
4\end{array}$ & $\begin{array}{c}130-134 \\
08-12\end{array}$ & $\begin{array}{l}4.30 \\
4.60\end{array}$ & & & & & & $42.7^{\mathrm{a}}$ & 66.4 & 1.56 & & & & 36.11 \\
\hline 1 & 4 & $108-112$ & 5.60 & & & & & & & & & & & & 32.11 \\
\hline & CC & 04-08 & & & & & & & 37.1 & 60.89 & & & & & 30.16 \\
\hline 2 & 1 & $58-62$ & 9.60 & & & & & & 43.9 & 67.83 & & & & & 34.20 \\
\hline 2 & 1 & $143-145$ & 10.45 & & & & & & 43.7 & 67.2 & & & & & 26.06 \\
\hline 2 & 2 & $122-126$ & 11.75 & & & & & & 40.9 & $\begin{array}{l}64.6 \\
65.9\end{array}$ & 21.49 & & & & 21.98 \\
\hline 2 & 3 & $133-137$ & 13.35 & & & & & & 42.3 & 65.9 & 21.49 & & & & \\
\hline 2 & 4 & $96-100$ & 14.50 & & & & & & $38.2^{\mathrm{a}}$ & 61.8 & & & & & 56.84 \\
\hline 2 & 5 & $116-120$ & 16.20 & & & & & & 36.4 & 60.2 & & & & & 44.94 \\
\hline 2 & 6 & $98-103$ & 17.50 & & & & & & 40.5 & 64.2 & & & & & $\begin{array}{l}56.94 \\
47.85\end{array}$ \\
\hline 3 & 2 & $137-141$ & 21.40 & & & & & & 37.7 & 61.5 & & & & & \\
\hline & 3 & $101-103$ & 22.51 & & & & & & 33.4 & 57.0 & 167 & & & & $\begin{array}{l}57.43 \\
47.86\end{array}$ \\
\hline 3 & 4 & $102-106$ & 24.05 & & & & & & $34.1^{\mathrm{a}}$ & 57.0 & 1.67 & & & & $\begin{array}{l}47.86 \\
34.60\end{array}$ \\
\hline 3 & 5 & $106-109$ & 25.59 & & & & & & 35.4 & 59.13 & & & & & $\begin{array}{l}34.60 \\
36.08\end{array}$ \\
\hline 3 & 6 & $81-84$ & 26.82 & & & & & & 36.3 & 60.07 & & & & & $\begin{array}{l}36.08 \\
40.49\end{array}$ \\
\hline 3 & 7 & $117-121$ & $\begin{array}{l}28.70 \\
30.6\end{array}$ & & & & & & 35.2 & 58.92 & & & & & $\begin{array}{l}40.49 \\
72.89\end{array}$ \\
\hline $\begin{array}{l}4 \\
4\end{array}$ & $\begin{array}{l}2 \\
3\end{array}$ & $\begin{array}{l}108-112 \\
139-142\end{array}$ & $\begin{array}{l}30.6 \\
32.40\end{array}$ & & & & & & $\begin{array}{l}35.2 \\
37.9^{\mathrm{a}}\end{array}$ & $\begin{array}{l}31.92 \\
61.4\end{array}$ & 1.62 & & & & 80.99 \\
\hline 4 & 4 & $50-53$ & 33.00 & & & & & & 34.6 & 58.28 & & & & & 59.32 \\
\hline 4 & 5 & $61-65$ & 34.65 & & & & & & 34.4 & 58.06 & & & & & 44.18 \\
\hline 5 & 6 & $102-105$ & 46.55 & & & & & & 32.2 & 55.63 & & & & & 55.96 \\
\hline 5 & CC & $7-10$ & 47.10 & & & & & & $36.3^{\mathrm{a}}$ & 58.5 & 1.61 & & & & 45.92 \\
\hline 5 & CC & $18-20$ & 47.20 & & & & & & & & & 56.9 & 58.88 & 1.701 & \\
\hline 6 & 5 & $140-143$ & 54.40 & & & & & & $38.4^{\mathrm{a}}$ & 60.9 & 1.59 & & & & 112.64 \\
\hline 6 & 5 & $63-67$ & 53.65 & & & & & & 37.1 & 60.89 & & & & & 59.64 \\
\hline 7 & 1 & $76-80$ & 57.30 & & & 185 & & 80.93 & 33.0 & $\begin{array}{l}56.53 \\
63.7\end{array}$ & 1.56 & & & & 39.04 \\
\hline 7 & 2 & $\begin{array}{c}66-70 \\
123-127\end{array}$ & $\begin{array}{l}58.7 \\
60.75\end{array}$ & & & 1.85 & & 50.93 & $\begin{array}{l}40,7^{\mathrm{a}} \\
39.6^{\mathrm{a}}\end{array}$ & $\begin{array}{l}63.7 \\
62.5\end{array}$ & $\begin{array}{l}1.56 \\
1.58\end{array}$ & & & & 122.22 \\
\hline 7 & $\begin{array}{l}3 \\
3\end{array}$ & $\begin{array}{c}123-127 \\
51-53\end{array}$ & 60.02 & & & & & & 39.0 & & & 65.7 & 62.05 & 1.63 & \\
\hline 8 & 1 & $116-120$ & 67.20 & & & & & & 35.4 & 59.13 & & & & & \\
\hline 8 & 2 & $102-106$ & 68.55 & & & & & & $36.4^{\mathrm{a}}$ & 59.4 & 1.63 & & & & 71.42 \\
\hline 8 & 3 & $121-125$ & 70.25 & & & & & & 34.5 & 58.17 & & & & & 106.76 \\
\hline 8 & 4 & $101-104$ & 71.53 & & & 1.99 & & 42.64 & $40.0^{\mathrm{a}}$ & 62.6 & 1.57 & & & & 105.28 \\
\hline 9 & 1 & $121-125$ & 76.75 & & & & & & $34.7^{\mathrm{a}}$ & 57.2 & 1.65 & & & & 88.35 \\
\hline 9 & 2 & $30-34$ & 77.30 & & & & & & & & & & & & 77.31 \\
\hline 9 & 2 & $135-138$ & 78.35 & & & & & & 35.8 & 59.55 & & & & & 87.93 \\
\hline 9 & 5 & $48-51$ & 82.00 & & & 1.95 & & 44.90 & & & & & & & \\
\hline 10 & 1 & $70-74$ & 86.24 & & & & & & 37.4 & 61.20 & & & & & 100.15 \\
\hline 10 & 1 & $137-141$ & 86.90 & & & & & & 38.0 & 61.80 & & & & & \\
\hline $\begin{array}{l}10 \\
10\end{array}$ & 2 & $\begin{array}{c}139-143 \\
33-37\end{array}$ & $\begin{array}{l}88.40 \\
88.85\end{array}$ & & & & & & $\begin{array}{l}36.8^{\mathrm{a}} \\
34.7\end{array}$ & $\begin{array}{l}59.4 \\
58.38\end{array}$ & 1.61 & & & & $\begin{array}{l}73.28 \\
90.37\end{array}$ \\
\hline
\end{tabular}


GEOTECHNICAL PROPERTIES, MIDDLE AMERICA TRENCH

\begin{tabular}{|c|c|c|c|}
\hline & & & \\
\hline & & Interval & $\begin{array}{l}\text { Sub-bottom } \\
\text { Depth }\end{array}$ \\
\hline Core & Section & $(\mathrm{cm})$ & \\
\hline Hole & 90 (Cont. & & \\
\hline 10 & 4 & $58-61$ & 90.60 \\
\hline 11 & 1 & $49-51$ & 95,01 \\
\hline 12 & 2 & $52-56$ & 106.05 \\
\hline 12 & 2 & $93-96$ & 106.45 \\
\hline 12 & 2 & $134-137$ & 106.85 \\
\hline 15 & 1 & $120-124$ & 133.70 \\
\hline 15 & 2 & $138-141$ & 135.40 \\
\hline 15 & 3 & $64-67$ & 136.15 \\
\hline 15 & 4 & $21-26$ & 137.25 \\
\hline 15 & 5 & $54-59$ & 139.05 \\
\hline 15 & 6 & $30-35$ & 140.25 \\
\hline 16 & 1 & $98-101$ & 143.0 \\
\hline 16 & 2 & $63-67$ & 144.15 \\
\hline 16 & 3 & $29-33$ & 145.30 \\
\hline 16 & 3 & $40-43$ & 145.40 \\
\hline 16 & 3 & $76-79$ & 145.78 \\
\hline 16 & 3 & $76-79$ & 145.78 \\
\hline 16 & 4 & $5-7$ & 146.55 \\
\hline 17 & 1 & $105-108$ & 152.55 \\
\hline 17 & 2 & $119-123$ & 154.20 \\
\hline 17 & 3 & $57-61$ & 155.10 \\
\hline 17 & 4 & $49-53$ & 156.50 \\
\hline 17 & 4 & $49-53$ & 156.50 \\
\hline 17 & 4 & $73-75$ & 156.25 \\
\hline 18 & 1 & $63-66$ & 161.65 \\
\hline 18 & 2 & $114-117$ & 163.65 \\
\hline 18 & 3 & $33-36$ & 164.35 \\
\hline 18 & 4 & $56-59$ & 166.58 \\
\hline 18 & 4 & $120-123$ & 166.73 \\
\hline 18 & 4 & $123-125$ & 166.76 \\
\hline 18 & 5 & $10-12$ & 167.10 \\
\hline 18 & 5 & $31-33$ & 167.32 \\
\hline 19 & 1 & $143-146$ & 171.95 \\
\hline 19 & 2 & $53-56$ & 172.55 \\
\hline 20 & $i$ & $103-107$ & 181.05 \\
\hline 20 & 2 & $91-94$ & 182.43 \\
\hline 20 & 2 & $127-131$ & 182.78 \\
\hline 20 & 3 & $27-32$ & 183.30 \\
\hline 20 & 3 & $129-132$ & 184.30 \\
\hline 20 & 4 & $93-94$ & 185.44 \\
\hline 20 & 4 & $94-97$ & 185.45 \\
\hline 20 & 5 & $76-80$ & 186.80 \\
\hline 20 & 6 & $77-81$ & 188.30 \\
\hline 21 & 1 & $126-131$ & 190.80 \\
\hline 21 & 2 & $135-139$ & 192.35 \\
\hline 21 & 3 & $110-112$ & 193.60 \\
\hline 21 & 4 & $53-57$ & 194.55 \\
\hline 21 & 4 & $76-79$ & 194.76 \\
\hline 21 & 5 & $92-96$ & 196.45 \\
\hline 21 & 6 & $86-90$ & 197.90 \\
\hline 22 & 1 & $129-133$ & 200.30 \\
\hline 22 & 2 & $119-123$ & 201.70 \\
\hline 22 & 3 & $91-94$ & 202.92 \\
\hline 22 & 4 & $80-83$ & 204.30 \\
\hline 22 & 5 & $85-89$ & 205.85 \\
\hline 22 & 6 & $20-27$ & 207.25 \\
\hline 23 & 1 & $130-132$ & 209.80 \\
\hline 23 & 2 & $45-48$ & 210.45 \\
\hline 23 & 3 & $74-77$ & 212.25 \\
\hline 23 & 4 & $40-44$ & 213.40 \\
\hline 23 & 5 & $55-58$ & 215.05 \\
\hline 23 & 6 & $49-53$ & 216.50 \\
\hline 23 & 6 & $102-105$ & 217.55 \\
\hline 23 & 7 & $67-71$ & 218.10 \\
\hline 24 & 1 & $118-120$ & 218.2 \\
\hline 24 & 2 & $93-97$ & 220.4 \\
\hline 24 & 3 & $110-114$ & 222.10 \\
\hline 24 & 4 & $94-97$ & 223.45 \\
\hline 25 & 1 & $27-31$ & 227.80 \\
\hline 25 & 2 & $121-124$ & 230.72 \\
\hline 25 & 3 & $46-49$ & 230.98 \\
\hline 25 & 4 & $91-94$ & 232.92 \\
\hline 25 & 5 & $13-17$ & 233.65 \\
\hline 25 & 6 & $131-133$ & 236.32 \\
\hline 26 & 3 & 06-08 & 240.06 \\
\hline 26 & 4 & $52-57$ & 242.05 \\
\hline 26 & 5 & $100-105$ & 244.00 \\
\hline 26 & 6 & $101-105$ & 245.55 \\
\hline 27 & 1 & $105-108$ & 247.55 \\
\hline 27 & 2 & $118-122$ & 249.20 \\
\hline 27 & 3 & $82-86$ & 250.35 \\
\hline 28 & 1 & $86-89$ & 256.86 \\
\hline 28 & 2 & $76-79$ & 258.26 \\
\hline 28 & 3 & $78-82$ & 259.80 \\
\hline 28 & 3 & $119-122$ & 260.20 \\
\hline 28 & 4 & $73-77$ & 261.25 \\
\hline 28 & 5 & $73-76$ & 262.76 \\
\hline 28 & 5 & $109-112$ & 263.11 \\
\hline 28 & 6 & $80-83$ & 264.30 \\
\hline 29 & 1 & $131-134$ & 266.83 \\
\hline 29 & 2 & $120-124$ & 268.2 \\
\hline
\end{tabular}




\begin{tabular}{|c|c|c|c|c|c|c|c|c|c|c|c|}
\hline & & & & $\begin{array}{c}\text { Contin } \\
\text { GRA }\end{array}$ & $\begin{array}{l}\text { uous } \\
\text { PE }\end{array}$ & Two & Minute $\mathrm{GF}$ & RAPE & Rock $\mathrm{Cl}$ & unk or Gra & vimetric $^{\mathrm{a}}$ \\
\hline Core & Section & $\begin{array}{c}\text { Interval } \\
(\mathrm{cm})\end{array}$ & $\begin{array}{l}\text { Sub-bottom } \\
\text { Depth } \\
\text { (m) }\end{array}$ & $\begin{array}{c}\text { Bulk } \\
\text { Density } \\
\left(\mathrm{Mg} / \mathrm{m}^{3}\right)\end{array}$ & $\begin{array}{c}\text { Porosity } \\
\left(\%^{\circ}\right)\end{array}$ & $\begin{array}{c}\text { Bulk } \\
\text { (Mg } \\
\text { Parallel }\end{array}$ & $\begin{array}{l}\text { ensity } \\
\left.m^{3}\right)^{\text {Normal }}\end{array}$ & $\begin{array}{c}\text { Porosity } \\
(\%)\end{array}$ & $\begin{array}{l}\text { Water } \\
\text { Content } \\
(\%)\end{array}$ & $\begin{array}{c}\text { Porosity } \\
(\%)\end{array}$ & $\begin{array}{c}\text { Bulk } \\
\text { Density } \\
\left(\mathrm{Mg} / \mathrm{m}^{3}\right)\end{array}$ \\
\hline Hole 4 & 90 (Cont. & & & & & & & & & & \\
\hline 29 & 3 & 93-97 & 269.45 & & & & & & $28.3^{\mathrm{a}}$ & 52.5 & 1.86 \\
\hline 29 & 4 & $91-94$ & 270.92 & & & & & & 26.8 & 49.15 & \\
\hline 30 & 1 & $50-53$ & 275.0 & & & & & & 21.9 & 42.54 & \\
\hline 30 & 2 & $50-53$ & 277.0 & & & & & & 25.3 & 47.21 & \\
\hline 30 & 3 & $10-14$ & 278.10 & & & & & & $27.1^{\mathrm{a}}$ & 49.3 & 1.82 \\
\hline 31 & 2 & $23-27$ & 284.75 & & & & & & $26.2^{\mathrm{a}}$ & 48.3 & 1.84 \\
\hline 33 & 1 & 93-97 & 299.95 & & & & & & 22.7 & 43.67 & \\
\hline 35 & 1 & $115-118$ & 314.15 & & & & & & 20.0 & 39.76 & \\
\hline 35 & 2 & $87-91$ & 315.40 & & & & & & & & \\
\hline 35 & 3 & 98-102 & 317.00 & & & & & & & & \\
\hline 35 & 4 & $123-127$ & 318.75 & & & & & & 20.7 & 40.80 & \\
\hline 35 & 5 & $43-46$ & 319.95 & & & & & & & & \\
\hline 36 & 1 & $138-141$ & 323.90 & & & & & & $22.4^{\mathrm{a}}$ & 43.2 & 1.93 \\
\hline 36 & 3 & $132-135$ & 326.85 & & & & & & 22.9 & 43.95 & \\
\hline 36 & 5 & $130-135$ & 329.85 & & & & & & 20.1 & 39.91 & \\
\hline 37 & 1 & $87-91$ & 332.90 & & & & & & $21.8^{\mathrm{a}}$ & 42.6 & 1.96 \\
\hline 37 & 2 & $94-97$ & 334.45 & & & & & & 23.3 & 44.51 & \\
\hline 38 & 2 & $77-80$ & 342.30 & & & & & & $23.4^{\mathrm{a}}$ & 44.9 & 1.92 \\
\hline 38 & 4 & 88-92 & 346.90 & & & & & & $23.7^{\mathrm{a}}$ & 45.3 & 1.91 \\
\hline 38 & 5 & $87-91$ & 348.40 & & & & & & 22.0 & 42.68 & \\
\hline 39 & 1 & $81-83$ & 351.82 & & & & & & 21.2 & $\begin{array}{l}41.53 \\
4587\end{array}$ & \\
\hline 39 & 4 & $50-53$ & 356.00 & & & & & & 24.3 & 45.87 & \\
\hline 39 & 6 & $81-84$ & 359.30 & & & & & & $21.12^{\mathrm{a}}$ & 42.00 & 1.95 \\
\hline 40 & 4 & $60-63$ & 365.00 & & & & & & & 45,7 & \\
\hline & 5 & $87-91$ & 367.4 & & & & & & 20.4 & 45.47 & \\
\hline 40 & 7 & $32-35$ & 369.85 & & & & & & $22.0^{\mathrm{a}}$ & 42.7 & 1.94 \\
\hline 41 & 1 & $138-141$ & 371.40 & & & & & & & & \\
\hline 41 & 2 & $45-47$ & 371.95 & & & & & & $\begin{array}{l}20.9 \\
207 \mathrm{a}\end{array}$ & $\begin{array}{l}41.09 \\
41.3\end{array}$ & \\
\hline 42 & 1 & $50-53$ & 380.00 & & & & & & $\begin{array}{l}20.7^{\mathrm{a}} \\
19.4\end{array}$ & $\begin{array}{l}41.3 \\
38.85\end{array}$ & 1.99 \\
\hline & $\begin{array}{l}4 \\
1\end{array}$ & $\begin{array}{l}88-92 \\
74-76\end{array}$ & & & & & & & $\begin{array}{l}19.4 \mathrm{a} \\
20 . \mathrm{I}^{\mathrm{a}}\end{array}$ & $\begin{array}{l}38.85 \\
40.3\end{array}$ & 2.01 \\
\hline $\begin{array}{l}43 \\
43\end{array}$ & 1 & $\begin{array}{c}4-70 \\
101-103\end{array}$ & $\begin{array}{l}389.75 \\
390.02\end{array}$ & & & & & & $16.96^{\mathrm{a}}$ & 35.6 & 2.10 \\
\hline 43 & 2 & $78-82$ & 391.30 & & & & & & $20.3^{\mathrm{a}}$ & 40.8 & 2.01 \\
\hline 43 & 3 & $68-71$ & 392.70 & & & & & & $20.9^{\mathrm{a}}$ & 41.3 & 1.98 \\
\hline 43 & 3 & $118-121$ & 393.20 & & & & & & 23.0 & & \\
\hline 44 & 1 & $120-123$ & & & & & & & & & \\
\hline 44 & 1 & $123-125$ & 399.75 & & & & & & $21.8^{\mathrm{a}}$ & 42.6 & 1.96 \\
\hline 44 & 2 & $\begin{array}{c}108-112 \\
47-49\end{array}$ & $\begin{array}{l}401.10 \\
400.48\end{array}$ & & & & & & 19.9 & & \\
\hline $\begin{array}{l}44 \\
47\end{array}$ & ${ }_{1}^{2}$ & $\begin{array}{l}47-49 \\
62-65\end{array}$ & $\begin{array}{l}400.48 \\
418.18\end{array}$ & & & & & & $22.8^{\mathrm{a}}$ & 43.8 & 1.92 \\
\hline $\begin{array}{l}47 \\
47\end{array}$ & 1 & $65-68$ & 418.18 & & & & & & $17.9^{\mathrm{a}}$ & 36.4 & 2.04 \\
\hline 47 & i & $108-112$ & 418.60 & & & & & & $18.5^{\mathrm{a}}$ & 37.3 & 2.02 \\
\hline 48 & i & $142-145$ & 428.45 & & & & & & $16.7^{\mathrm{a}}$ & 34.61 & 2.09 \\
\hline 48 & 1 & $142-145$ & 428.45 & & & & & & & & \\
\hline 49 & i & $123-127$ & 437.75 & & & & & & $15.6^{\mathrm{a}}$ & 32.0 & 2.11 \\
\hline 49 & 2 & $91-93$ & 438.92 & & & & & & 16.3 & 33.96 & \\
\hline 49 & 2 & $91-93$ & 438.92 & & & & & & $15, \mathrm{~s}^{\mathrm{a}}$ & & \\
\hline so & 1 & $62-64$ & 446.64 & & & 1.97 & & 43.64 & $15.5^{\mathrm{a}}$ & 32.8 & 2.11 \\
\hline 50 & CC & $5-7$ & 455.05 & & & $\begin{array}{l}1.97 \\
1.97\end{array}$ & & $\begin{array}{l}43.04 \\
43.64\end{array}$ & $22.5^{\mathrm{a}}$ & 43.4 & \\
\hline 51 & 1 & $81-83$ & 45 & & & & & & $17.2^{\mathrm{a}}$ & $\begin{array}{l}43.4 \\
35.6\end{array}$ & $\begin{array}{l}1.93 \\
2.07\end{array}$ \\
\hline 52 & CC & $5-7$ & 465.55 & & & & & & $19.9^{\mathrm{a}}$ & $\begin{array}{l}39.4 \\
39.4\end{array}$ & $\begin{array}{l}2.07 \\
1.98\end{array}$ \\
\hline 53 & 1 & $73-76$ & 475.25 & & & & & & & & \\
\hline 53 & 1 & $88-91$ & 475.40 & & & 2.08 & & 37.19 & 16.5 & 34.28 & \\
\hline $\begin{array}{l}54 \\
54\end{array}$ & $\frac{1}{2}$ & $\begin{array}{c}105-108 \\
41-43\end{array}$ & $\begin{array}{l}485.05 \\
485.92\end{array}$ & & & & & & 17.6 & 36.06 & \\
\hline 54 & 3 & $65-67$ & $\begin{array}{l}483.92 \\
487.65\end{array}$ & & & & & & $19.6^{\mathrm{a}}$ & 39.3 & 2.00 \\
\hline $\begin{array}{l}54 \\
54\end{array}$ & 4 & $\begin{array}{l}55-67 \\
54-57\end{array}$ & 489.05 & & & & & & $17.7^{\mathrm{a}}$ & 36.5 & 2.06 \\
\hline $\begin{array}{l}54 \\
55\end{array}$ & 1 & $123-127$ & 45 & & & & & & 17.3 & 35.58 & 2.00 \\
\hline 55 & 2 & $138-141$ & 45. & & & & & & $20.1^{\mathrm{a}}$ & 40.0 & 1.99 \\
\hline 55 & 3 & $107-110$ & 497.60 & & & & & & 16.1 & $\begin{array}{r}34.61 \\
3.55\end{array}$ & \\
\hline 55 & 4 & $27-31$ & 498.30 & & & 2.07 & & 37.86 & 19.2 & 38.55 & \\
\hline 55 & 4 & $65-67$ & 498.65 & & & & & & & & \\
\hline 56 & 2 & $116-119$ & $\begin{array}{l}505.70 \\
506.95\end{array}$ & & & & & & $19.0^{\mathrm{a}}$ & & \\
\hline 56 & 3 & & $\begin{array}{l}506.95 \\
508.45\end{array}$ & & & 2.14 & & 33.45 & $\begin{array}{l}19.0^{\mathrm{a}} \\
18.8\end{array}$ & 38.5 & 2.03 \\
\hline 56 & 4 & $92-96$ & $\begin{array}{l}508.45 \\
510.10\end{array}$ & & & 2.14 & & 33.45 & & 37.94 & \\
\hline 56 & 5 & $110-112$ & $\begin{array}{l}510.10 \\
512.65\end{array}$ & & & & & & $\begin{array}{l}18.7^{\mathrm{a}} \\
18.5\end{array}$ & 38.0 & 2.03 \\
\hline 57 & $i$ & $14-17$ & $\begin{array}{l}512.65 \\
513.6\end{array}$ & & & & & & & 37.47 & \\
\hline $\begin{array}{l}57 \\
57\end{array}$ & $\frac{1}{2}$ & $\begin{array}{c}108-111 \\
66-69\end{array}$ & $\begin{array}{l}513.6 \\
514.68\end{array}$ & & & 2.07 & & 37.75 & $18.8^{\mathrm{a}}$ & 38.1 & 2.03 \\
\hline 57 & 3 & $\begin{array}{l}60-69 \\
49-52\end{array}$ & s1 & & & & & & & & \\
\hline 57 & 4 & $112-115$ & $\begin{array}{l}518.15 \\
519.25\end{array}$ & & & & & & $16.4^{\mathrm{a}}$ & 34.4 & 2.10 \\
\hline 57 & 5 & $75-78$ & $\begin{array}{l}519.25 \\
\$ 20.10\end{array}$ & & & & & & & & \\
\hline 57 & 6 & $108-111$ & $\begin{array}{l}\$ 20.10 \\
\$ 25.75\end{array}$ & & & & & & 21.5 & 41.96 & \\
\hline 58 & 3 & $73-76$ & $\begin{array}{l}525.75 \\
526.45\end{array}$ & & & & & & & & \\
\hline $\begin{array}{l}58 \\
58\end{array}$ & $\begin{array}{l}3 \\
4\end{array}$ & $\begin{array}{c}143-147 \\
93-96\end{array}$ & $\begin{array}{l}526.45 \\
527.45\end{array}$ & & & & & & $\begin{array}{l}22.0 \\
19.7^{\mathrm{a}}\end{array}$ & $\begin{array}{l}42.68 \\
39.8\end{array}$ & 2.02 \\
\hline $\begin{array}{l}58 \\
58\end{array}$ & $\begin{array}{l}4 \\
5\end{array}$ & $\begin{array}{r}93-960 \\
86-89\end{array}$ & 528 & & & & & & & & \\
\hline 58 & 5 & $147-150$ & 529.50 & & & 2.11 & & 35.00 & & & \\
\hline 58 & 6 & $65-68$ & 530.15 & & & & & & $16.9^{\mathrm{a}}$ & 35.4 & 2.09 \\
\hline 59 & 2 & $96-99$ & 533.98 & & & 2.12 & & 34.5 & 20.5 & 40.50 & \\
\hline 59 & 3 & $50-53$ & 535.0 & & & & & & $21.1^{\mathrm{a}}$ & 40.4 & 2.01 \\
\hline 59 & 4 & $60-62$ & 536.60 & & & & & & 18.5 & 37.47 & \\
\hline 60 & $\frac{1}{2}$ & $\begin{array}{l}82-84 \\
58-62\end{array}$ & $\begin{array}{l}541.83 \\
543,10\end{array}$ & & & & & & $16.5^{\mathrm{a}}$ & 34.7 & 2.11 \\
\hline $\begin{array}{l}60 \\
60\end{array}$ & 2 & $\begin{array}{l}58-62 \\
72-74\end{array}$ & $\begin{array}{l}543.10 \\
543.23\end{array}$ & & & 2.03 & & 40.11 & 20.9 & 41.09 & \\
\hline 60 & 4 & $38-41$ & 545.90 & & & & & & & & \\
\hline 61 & $i$ & $131-133$ & 551.82 & & & & & & 18.9 & 38.09 & \\
\hline 61 & 2 & $75-77$ & 552.75 & & & & & & $18.6^{\mathrm{a}}$ & 38.0 & 2.05 \\
\hline 61 & 3 & $\begin{array}{l}50-53 \\
56-58\end{array}$ & $\begin{array}{l}554.0 \\
555.57\end{array}$ & & & 2.10 & & 35.9 & 19.1 & 38.40 & \\
\hline $\begin{array}{l}61 \\
62\end{array}$ & 4 & $\begin{array}{l}56-58 \\
40-42\end{array}$ & $\begin{array}{l}555.57 \\
560.40\end{array}$ & & & & & & 22.2 & 42.97 & \\
\hline
\end{tabular}




\begin{tabular}{|c|c|c|c|c|}
\hline & & & & $\begin{array}{l}\text { Contir } \\
\text { GRA }\end{array}$ \\
\hline & & Interval & $\begin{array}{l}\text { Sub-bottom } \\
\text { Depth }\end{array}$ & $\begin{array}{c}\text { Bulk } \\
\text { Density }\end{array}$ \\
\hline Core & Section & (cm) & & \\
\hline Hole & 190 (Cont. & & & \\
\hline 62 & 3 & $50-53$ & 563.5 & \\
\hline 62 & 4 & $121-123$ & 565.72 & \\
\hline $\begin{array}{l}62 \\
63\end{array}$ & $\begin{array}{l}4 \\
1\end{array}$ & $50-53$ & 565.0 & \\
\hline $\begin{array}{l}63 \\
63\end{array}$ & $\begin{array}{l}1 \\
2\end{array}$ & $\begin{array}{c}107-109 \\
63-65\end{array}$ & 570.58 & \\
\hline 63 & 2 & $128-130$ & $\begin{array}{l}571.65 \\
572.30\end{array}$ & \\
\hline 64 & 2 & $18-20$ & 580.7 & \\
\hline Hole & & & & \\
\hline 1 & 1 & $49-51$ & 0.50 & \\
\hline 1 & 2 & $113-116$ & 2.65 & \\
\hline 1 & 3 & $125-128$ & 4.25 & \\
\hline 1 & 4 & $127-130$ & 5.80 & \\
\hline i & 5 & $57-60$ & 6.60 & \\
\hline 1 & 5 & $90-93$ & 6.90 & \\
\hline 2 & 2 & $135-137$ & 11.35 & \\
\hline 2 & 3 & $110-113$ & 14.10 & \\
\hline 2 & 4 & $27-30$ & 14.80 & \\
\hline 2 & 4 & $85-87$ & 15.35 & \\
\hline 2 & 4 & $119-122$ & 15.70 & \\
\hline 2 & 4 & $145-147$ & 15.95 & \\
\hline 2 & 5 & $7-10$ & 16.10 & \\
\hline 3 & 1 & $130-133$ & 20.80 & \\
\hline 3 & 2 & $102-105$ & 22.05 & \\
\hline 3 & 3 & $113-116$ & 23.65 & \\
\hline 3 & 4 & $18-21$ & 24.20 & \\
\hline 3 & 6 & $31-34$ & 27.33 & \\
\hline 3 & 7 & $33-36$ & 28.85 & \\
\hline 4 & 4 & $96-98$ & 34.47 & \\
\hline 4 & 5 & $45-48$ & 35.45 & \\
\hline 4 & 5 & $123-126$ & 36.25 & \\
\hline 4 & $\mathrm{CC}$ & $13-15$ & 38.15 & \\
\hline 5 & 3 & $110-113$ & 42.10 & \\
\hline 5 & 3 & $118-120$ & 42.20 & \\
\hline 5 & 4 & $47-50$ & 43.00 & \\
\hline 6 & 2 & $76-79$ & 49.76 & \\
\hline 6 & 3 & $48-50$ & 51.00 & \\
\hline 6 & 3 & $97-100$ & 51.50 & \\
\hline 6 & 4 & $82-85$ & 52.85 & \\
\hline 6 & 5 & $99-102$ & 54.5 & \\
\hline 6 & 6 & $83-85$ & 55.85 & \\
\hline 6 & 7 & $8-11$ & 56.60 & \\
\hline 7 & 1 & $99-102$ & 58.5 & \\
\hline 7 & 2 & $119-122$ & 60.20 & \\
\hline 7 & 3 & $111-114$ & 61.13 & \\
\hline 7 & 4 & $48-51$ & 62.50 & \\
\hline 7 & 5 & $71-74$ & 64.23 & \\
\hline 7 & 6 & $89-92$ & 65.90 & \\
\hline 7 & 7 & $9-12$ & 66.60 & \\
\hline 8 & 1 & $109-112$ & 68.10 & \\
\hline 8 & 2 & $132-135$ & 69.85 & \\
\hline 8 & 4 & $106-109$ & 72.56 & \\
\hline 8 & 5 & $136-139$ & 74.36 & \\
\hline 8 & 6 & $128-131$ & 75.80 & \\
\hline 9 & 1 & $139-142$ & 77.90 & \\
\hline 9 & 2 & $113-116$ & 79.15 & \\
\hline 9 & 3 & $99-102$ & 80.50 & \\
\hline 9 & 5 & $48-51$ & 83.00 & \\
\hline 9 & 7 & $10-13$ & 85.60 & \\
\hline 10 & 5 & $79-82$ & 92.80 & \\
\hline 10 & 6 & $69-72$ & 94.20 & \\
\hline 11 & 2 & $117-120$ & 98.20 & \\
\hline 11 & 3 & $77-80$ & 100.80 & \\
\hline 14 & 3 & $59-62$ & 118.10 & \\
\hline 14 & 6 & $55-58$ & 122.55 & \\
\hline is & 1 & $98-101$ & 125.0 & \\
\hline 15 & 4 & $99-102$ & 129.5 & \\
\hline 15 & 5 & $98-101$ & 131.0 & \\
\hline is & 7 & $21-23$ & 133.21 & \\
\hline 16 & 1 & $119-122$ & 134.70 & \\
\hline 16 & 4 & $72-75$ & 138.75 & \\
\hline 16 & 4 & $108-111$ & 139.10 & \\
\hline 16 & 5 & 88-91 & 140.4 & \\
\hline 16 & 6 & $68-71$ & 141.70 & \\
\hline 16 & 6 & $98-100$ & 142.00 & \\
\hline 16 & 6 & $108-111$ & 142.10 & \\
\hline 17 & 1 & $101-103$ & 144.01 & \\
\hline 17 & 2 & $112-114$ & 145.6 & \\
\hline 17 & 4 & $115-118$ & 148.65 & \\
\hline 17 & 5 & $100-102$ & 150.00 & \\
\hline 17 & 5 & $125-127$ & 150.25 & \\
\hline 17 & 6 & $38-41$ & 150.90 & \\
\hline 17 & 6 & $138-141$ & 151.90 & \\
\hline 18 & $\mathrm{cC}$ & $12-14$ & 161.62 & \\
\hline 19 & 1 & $147-150$ & 163.35 & \\
\hline 19 & 3 & $35-38$ & 165.35 & \\
\hline 19 & 5 & $138-141$ & 167.40 & \\
\hline 21 & 3 & $101-104$ & 185.01 & \\
\hline 21 & 3 & $134-137$ & 185.35 & \\
\hline 21 & 4 & $7-10$ & 185.60 & \\
\hline 22 & 4 & 03-07 & 195.05 & \\
\hline 22 & 4 & $145-147$ & 196.45 & \\
\hline
\end{tabular}




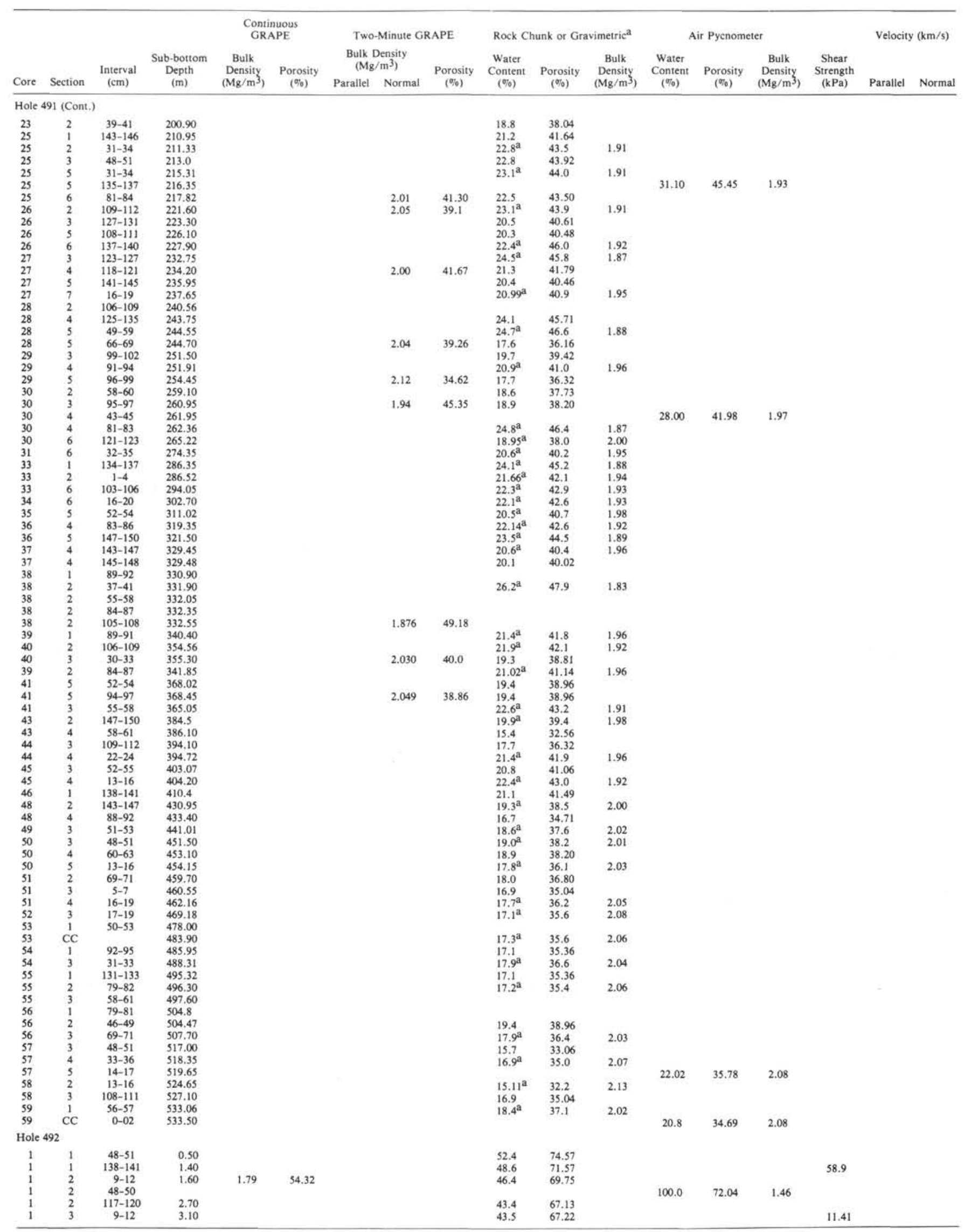




\begin{tabular}{|c|c|c|c|c|c|c|c|}
\hline & & & & $\begin{array}{r}\text { Conti } \\
\text { GRA }\end{array}$ & $\begin{array}{l}\text { uous } \\
\text { PE }\end{array}$ & Two & Minute GF \\
\hline & & & $\begin{array}{l}\text { Sub-bottom } \\
\text { Depth }\end{array}$ & $\begin{array}{c}\text { Bulk } \\
\text { Density }\end{array}$ & & $\begin{array}{l}\text { Bulk } \\
(\mathrm{Mg}\end{array}$ & $\begin{array}{l}\text { ensity } \\
\mathrm{m}^{3} \text { ) }\end{array}$ \\
\hline Core & Section & (cm) & & & $(\%)$ & Parallel & Normal \\
\hline Hole & 192 (Cont & & & & & & \\
\hline 2 & 2 & $130-133$ & 6.30 & 1.58 & 66.7 & & \\
\hline 2 & 3 & $\begin{array}{c}74-76 \\
109-122\end{array}$ & 7.25 & & & & \\
\hline 2 & 4 & $13-16$ & 8.15 & 1.66 & 61.70 & & \\
\hline 2 & 4 & $81-84$ & 8.80 & & & & \\
\hline 3 & 2 & $110-113$ & 16.60 & 1.78 & 54.71 & & \\
\hline 3 & 3 & $117-120$ & 17.20 & & & & \\
\hline 3 & 4 & $17-20$ & 17.70 & 1.76 & 55.98 & & \\
\hline 3 & 4 & $96-99$ & 18.45 & & & & \\
\hline 3 & 4 & $148-150$ & 19.19 & & & & \\
\hline 3 & 5 & $\begin{array}{l}16-19 \\
52-55\end{array}$ & $\begin{array}{l}19.19 \\
19.55\end{array}$ & & & & \\
\hline 4 & 1 & $105-108$ & $\begin{array}{l}19.55 \\
23.55\end{array}$ & & & & \\
\hline 4 & 6 & $23-26$ & 30.25 & 1.72 & 58.5 & & \\
\hline 4 & 6 & $125-128$ & 31.25 & & & & \\
\hline 4 & 7 & 34-37 & 31.85 & & & & \\
\hline 4 & CC & $10-12$ & 31.95 & & & & \\
\hline 5 & 1 & $137-140$ & 33.40 & & & & \\
\hline 5 & 2 & $18-21$ & 33.70 & 1.67 & 61.7 & & \\
\hline 5 & 2 & $137-140$ & 34.90 & .1.0 & 年, & & \\
\hline 5 & 3 & $50-52$ & 35.70 & & & & \\
\hline 5 & 3 & $121-124$ & 36.22 & 1.65 & 62.9 & & \\
\hline 5 & 4 & $95-98$ & 37.45 & & & & \\
\hline 5 & 4 & $108-111$ & 37.58 & & & & \\
\hline 5 & 5 & $99-101$ & 39.00 & & & & \\
\hline 5 & 4 & $18-21$ & 35.70 & & & & \\
\hline 5 & 5 & $9-11$ & 38.10 & & & & \\
\hline 6 & 1 & $135-138$ & 42.85 & & & & \\
\hline 6 & 2 & $22-25$ & 43.25 & & & & \\
\hline 6 & 2 & $108-110$ & 44.10 & & & & \\
\hline 6 & 4 & $136-139$ & 47.36 & & & & \\
\hline 6 & 5 & $48-50$ & 48.00 & & & & \\
\hline 6 & 5 & $120-123$ & 48.7 & 1.77 & 55.3 & & \\
\hline 6 & 6 & $71-74$ & 49.74 & & & & \\
\hline 7 & 3 & $33-36$ & 54.35 & & & & \\
\hline 7 & 3 & $53-56$ & 54.55 & & & & \\
\hline 8 & 1 & $99-102$ & 61.5 & & & & \\
\hline 8 & 2 & $29-32$ & 63.30 & & & & \\
\hline 8 & 3 & $57-60$ & 64.10 & 1.84 & 51.53 & & \\
\hline 8 & 3 & $110-112$ & 64.60 & & & & \\
\hline 8 & 4 & $\begin{array}{l}57-60 \\
93.96\end{array}$ & $\begin{array}{l}65.60 \\
77.45\end{array}$ & & & & \\
\hline 9 & 2 & $\begin{array}{l}93-96 \\
24-27\end{array}$ & $\begin{array}{l}72.45 \\
73.25\end{array}$ & 1.76 & 55.9 & & \\
\hline 9 & 3 & $\begin{array}{l}24-27 \\
36-39\end{array}$ & $\begin{array}{l}73.25 \\
79.89\end{array}$ & & & & \\
\hline 10 & $\begin{array}{l}1 \\
3\end{array}$ & 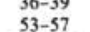 & 83.05 & & & & \\
\hline 10 & 4 & $100-103$ & 84.0 & & & & \\
\hline 11 & 1 & $29-31$ & 89.3 & & & & \\
\hline i1 & 2 & $85-88$ & 91.35 & 1.86 & 50.3 & & \\
\hline 11 & 2 & $148-150$ & 92.00 & & & & \\
\hline 11 & 3 & $57-60$ & 92.60 & & & & \\
\hline 11 & $\mathrm{CC}$ & $1-4$ & 98.02 & & & & \\
\hline 12 & 1 & $128-131$ & 99.80 & & 50.1 & & \\
\hline 12 & 2 & 98-101 & 101.0 & 1.86 & 50.1 & & \\
\hline 12 & 4 & $\begin{array}{l}62-64 \\
48-50\end{array}$ & $\begin{array}{l}102.14 \\
102.40\end{array}$ & & & & \\
\hline 12 & 4 & $106-109$ & 103.06 & & & & \\
\hline 12 & 5 & $42-44$ & 104.94 & 1.87 & 49.6 & & \\
\hline 13 & 2 & $110-113$ & 110.6 & & & & \\
\hline 13 & 3 & $12-15$ & 111.15 & & & & \\
\hline 14 & 1 & $135-137$ & 118.85 & & & & \\
\hline 14 & 3 & $67-70$ & 121.2 & & & & \\
\hline 14 & 3 & $113-116$ & 121.65 & & & & \\
\hline 14 & 3 & $142-145$ & 121.95 & & & & \\
\hline 14 & 5 & $121-125$ & 124.75 & & & & \\
\hline 14 & 6 & $136-139$ & 126.39 & & & & \\
\hline 15 & 1 & $67-70$ & 127.7 & & & & \\
\hline is & 2 & $95-98$ & 129.45 & & & & \\
\hline 15 & 3 & $113-116$ & 131.15 & & & & \\
\hline 16 & 3 & $28-31$ & 139.80 & & & & \\
\hline 16 & 4 & $0-3$ & 141.03 & & & & \\
\hline 16 & 5 & $19-22$ & 142.70 & & & & \\
\hline 16 & 5 & $22-25$ & 142.75 & & & & \\
\hline 16 & CC & $2-5$ & 145.55 & & & & \\
\hline 17 & 1 & $13-16$ & 146.15 & & & & \\
\hline 17 & 1 & $118-121$ & 147.20 & & & & \\
\hline 17 & 3 & $13-15$ & 149.15 & & & & \\
\hline 17 & 3 & $15-17$ & 149.15 & & & & \\
\hline 18 & 1 & 91-94 & 156.44 & & & & \\
\hline 18 & 3 & $56-59$ & 159.06 & & & & \\
\hline 18 & 3 & 98-101 & 159.50 & & & & \\
\hline 18 & 4 & $51-54$ & 160.51 & & & & \\
\hline 18 & $\mathrm{CC}$ & $0-3$ & 164.53 & & & & \\
\hline 19 & 1 & $147-150$ & 166.5 & & & & \\
\hline 19 & 2 & $13-16$ & 166.65 & & & & \\
\hline 19 & 3 & $84-87$ & 168.85 & & & & \\
\hline 22 & 3 & $73-75$ & 197.25 & & & & \\
\hline 22 & 3 & $75-78$ & 197.25 & & & & \\
\hline 22 & 5 & $57-61$ & 200.10 & & & & \\
\hline 23 & 1 & $23-25$ & 203.25 & & & & \\
\hline 23 & 4 & $138-141$ & 208.5 & & & & \\
\hline 23 & $\mathrm{CC}$ & $0-2$ & 212.03 & & & & \\
\hline
\end{tabular}




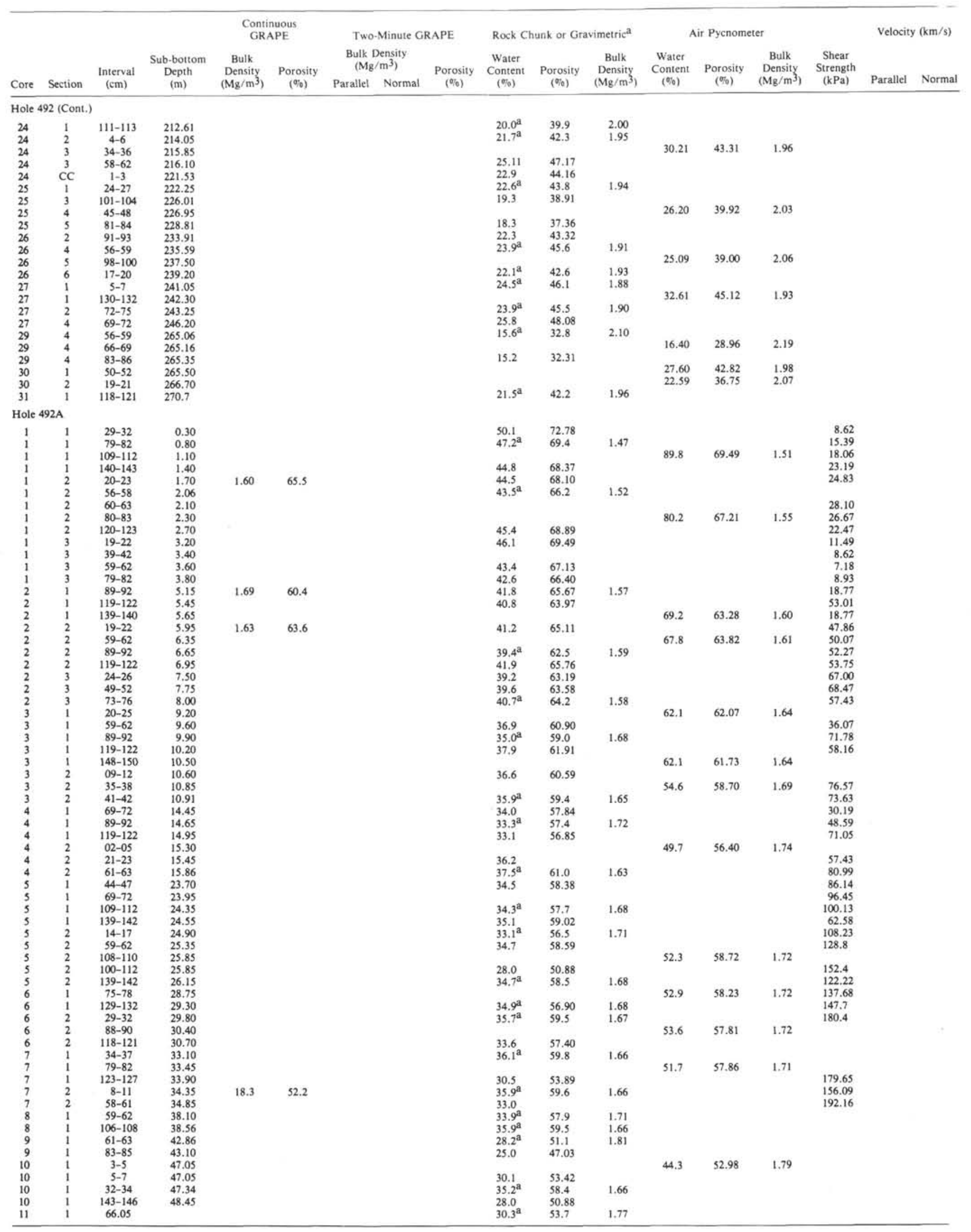




\begin{tabular}{|c|c|c|c|}
\hline & & & \\
\hline & & Interval & $\begin{array}{l}\text { Sub-bottom } \\
\text { Depth }\end{array}$ \\
\hline Core & Section & $(\mathrm{cm})$ & \\
\hline Hole 4 & & & \\
\hline 2 & 1 & $49-52$ & 120.50 \\
\hline 2 & 2 & $64-67$ & 122.15 \\
\hline 2 & 3 & $71-73$ & 123.71 \\
\hline 2 & 3 & $148-150$ & 124.50 \\
\hline 3 & 1 & $78-81$ & 130.3 \\
\hline 3 & 1 & $109-112$ & 130.60 \\
\hline 3 & 2 & $88-90$ & 131.90 \\
\hline 4 & 2 & $30-32$ & 140.80 \\
\hline 5 & 1 & $81-83$ & 149.31 \\
\hline 5 & 2 & $70-73$ & 150.70 \\
\hline 5 & 3 & $82-84$ & 152.32 \\
\hline 5 & 4 & $91-94$ & 153.91 \\
\hline 6 & 2 & $130-133$ & 160.8 \\
\hline 7 & 2 & $100-103$ & 170.0 \\
\hline 8 & 3 & $56-58$ & 180.56 \\
\hline 9 & i & $100-104$ & 187.5 \\
\hline 9 & 3 & $40-43$ & 189.9 \\
\hline 9 & 5 & $20-23$ & 192.7 \\
\hline 10 & i & $23-26$ & 196.25 \\
\hline 10 & 2 & $51-53$ & 198.01 \\
\hline 10 & 3 & $40-43$ & 199.40 \\
\hline 10 & 5 & $12-17$ & 202.15 \\
\hline 11 & 1 & $124-127$ & 206.75 \\
\hline ii & 2 & $67-70$ & 207.70 \\
\hline 13 & i & $66-69$ & 225.19 \\
\hline 14 & i & $80-83$ & 234.80 \\
\hline 14 & 2 & $37-41$ & 235.90 \\
\hline 14 & 5 & $19-23$ & 240.20 \\
\hline 15 & 1 & $100-102$ & 244.5 \\
\hline 15 & 3 & $99-101$ & 247.5 \\
\hline 15 & 4 & $34-36$ & 248.35 \\
\hline 17 & 1 & $126-129$ & 263.79 \\
\hline 17 & 2 & $31-35$ & 264.35 \\
\hline 17 & 3 & $70-74$ & 266.20 \\
\hline 17 & 3 & $135-138$ & 266.80 \\
\hline 18 & 4 & $122-125$ & 277.75 \\
\hline 18 & 5 & $85-88$ & 278.85 \\
\hline 18 & 6 & $91-94$ & 280.43 \\
\hline 19 & 2 & $147-150$ & 284.5 \\
\hline 19 & 4 & $147-150$ & 287.5 \\
\hline 19 & 5 & $127-130$ & 288.8 \\
\hline 20 & 1 & $124-126$ & 292.25 \\
\hline 20 & 3 & $100-103$ & 295.0 \\
\hline 20 & 5 & $84-87$ & 297.85 \\
\hline 20 & 7 & $36-38$ & 300.36 \\
\hline 21 & 2 & $102-104$ & 303.04 \\
\hline 21 & 4 & $83-84$ & 305.85 \\
\hline 21 & 5 & $65-67$ & 307.15 \\
\hline 22 & 1 & $43-45$ & 311.15 \\
\hline 22 & 3 & $104-106$ & 314.05 \\
\hline 22 & 4 & $46-48$ & 314.96 \\
\hline 22 & 5 & $71-73$ & 316.71 \\
\hline 23 & $\mathrm{CC}$ & $03-05$ & 328.55 \\
\hline 24 & 1 & $112-114$ & 330.12 \\
\hline 24 & 2 & $109-112$ & 331.14 \\
\hline 24 & 3 & $78-81$ & 80 \\
\hline 25 & 1 & $123-125$ & 75 \\
\hline 25 & 3 & $133-136$ & 342.85 \\
\hline 25 & 4 & $102-104$ & 344.03 \\
\hline 25 & 5 & $125-127$ & 345.75 \\
\hline 26 & 2 & $94-97$ & 350.45 \\
\hline 27 & $i$ & 124 & 358.75 \\
\hline 27 & 2 & $96-98$ & 359.97 \\
\hline 27 & 4 & $83-85$ & 362.85 \\
\hline 27 & 4 & $131-133$ & 363.32 \\
\hline 27 & 5 & $128-130$ & 364.80 \\
\hline 28 & i & $142-145$ & 368.45 \\
\hline 28 & 3 & $109-112$ & 371.10 \\
\hline 28 & 4 & $84-87$ & 372.35 \\
\hline 28 & 5 & $148-150$ & 374.50 \\
\hline 29 & 1 & 94-98 & 377.45 \\
\hline 29 & 2 & & 378.35 \\
\hline 29 & 3 & & 0 \\
\hline 29 & 5 & & 382.80 \\
\hline 30 & 1 & & 386.66 \\
\hline 30 & 3 & & 389.40 \\
\hline 30 & 4 & $47-50$ & 391.0 \\
\hline 30 & 5 & $96-100$ & 393.0 \\
\hline 30 & 6 & $54-58$ & 394.05 \\
\hline 31 & 1 & 2 & 396.30 \\
\hline 31 & 2 & $27-31$ & 397.30 \\
\hline 31 & 3 & 33-36 & 398.85 \\
\hline 31 & 5 & $62-66$ & 402.15 \\
\hline 31 & 6 & $42-46$ & 403.45 \\
\hline 32 & 1 & $92-95$ & 405.95 \\
\hline 32 & 2 & $4-7$ & 406.55 \\
\hline 32 & 3 & $123-127$ & 409.25 \\
\hline 33 & i & $74-77$ & 415.25 \\
\hline 33 & 2 & $7-10$ & 416.10 \\
\hline 33 & 3 & $113-116$ & 418.65 \\
\hline 33 & 6 & $106-109$ & 420.05 \\
\hline
\end{tabular}


L. E. SHEPHARD, W. R. BRYANT, W. A. CHIOU

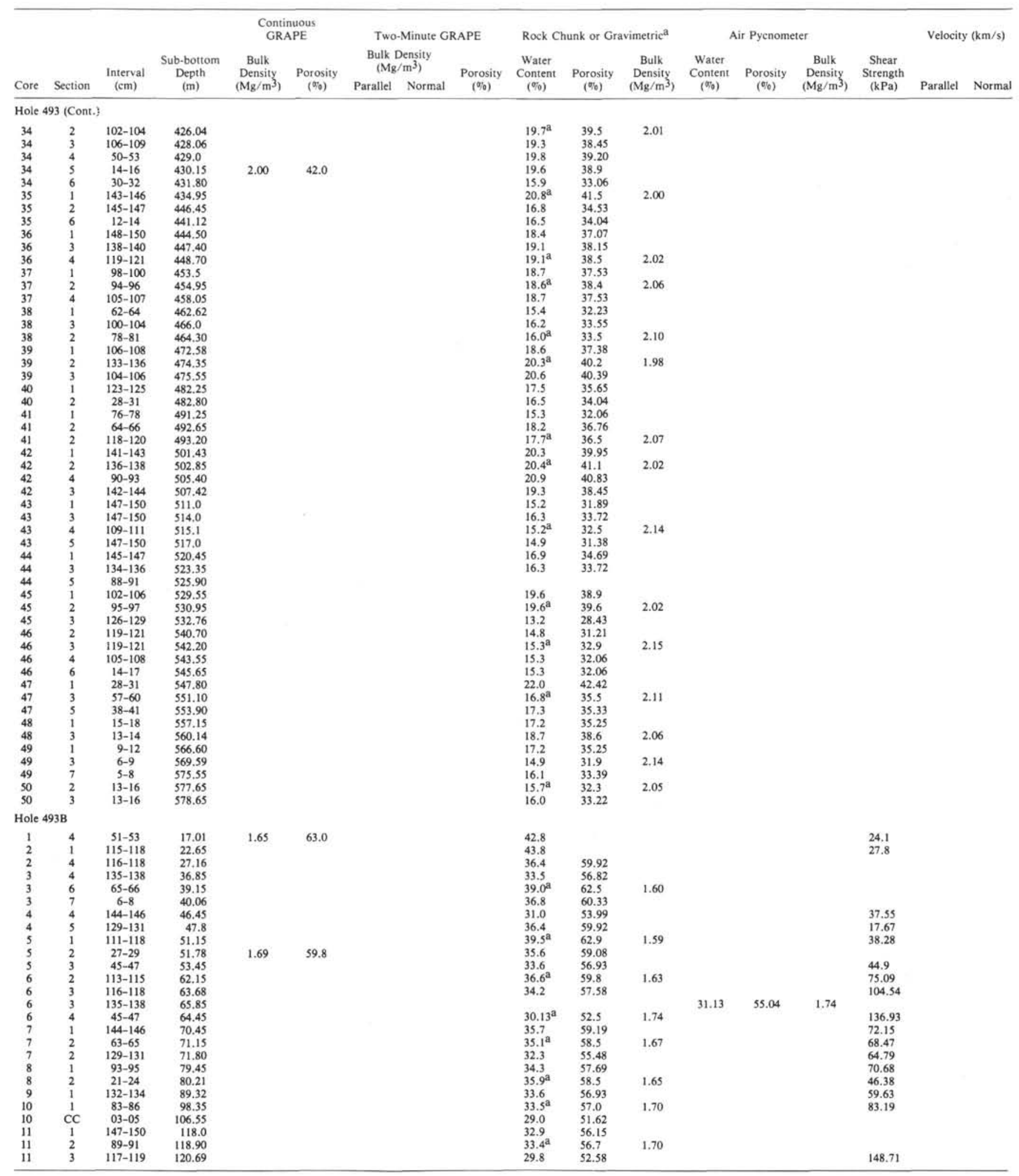

